\title{
Modernising the Constitution - A Parliament Act
}

\author{
Graham McBain ${ }^{1,2}$ \\ ${ }^{1}$ Peterhouse, Cambridge, UK \\ ${ }^{2}$ Harvard Law School, USA \\ Correspondence: Graham McBain, 21 Millmead Terrace, Guildford, Surrey GU2 4AT, UK. E-mail: \\ gsmcbain@aol.com
}

\author{
Received: January 6, 2021 Accepted: February 3, 2021 Online Published: February 12, 2021 \\ doi:10.5539/ilr.v10n1p101 URL: https://doi.org/10.5539/ilr.v10n1p101
}

A previous article has looked at modernising the law on the Crown, see Modernising the Constitution - A Crown Act. ${ }^{1}$ This article looks at the same in respect of Parliament. It may be noted, from the outset, that the legislation - and common law - on Parliament, is much simpler and less complicated than that on the Crown. Indeed, a large amount of this legislation is administrative (mundane) in nature. Also, much is non-contentious, having given rise to little caselaw. Further, there is a compelling case for consolidation since there are, presently, c. 68 Acts relating to Parliament, but they contain only c. 280 sections and much of the same is obsolete or couched in antiquated language which is scarcely intelligible. Thus, the essential issues are the following:

- Consolidation of Parliamentary Legislation;

- Modernising Crown Prerogatives relating to Parliament.

In the latter case, most Crown prerogatives are now obsolete - as reflects the position after the Glorious Revolution of 1688. And, the few worth retaining should be placed in legislation - in order to give greater consistency and coherency to the same.

In conclusion, all material (legislative and common law) relating to Parliament should now be consolidated into a Parliament Act. Most of this would not be contentious, being administrative in nature. However, a few issues concerning Parliament are contentious. They are also considered in this article.

\section{INTRODUCTION}

A prior article on the Crown has listed all (or almost all) the principal texts on constitutional law. ${ }^{2}$ Since this has been done in that article, it is not replicated here - save that Appendix $\boldsymbol{A}$ lists texts specific to Parliament. Further, unlike material on the Crown, most material on Parliament has - relatively rarely - been the source of contention before the courts. Thus, it is unsurprising that the first legal text of quality dedicated to considering the law on Parliament did not appear until mid-Victorian times. That is, the text by Thomas Erskine May, A Treatise upon the Law, Privileges, Proceedings and Usage of Parliament (1844) ('May'). ${ }^{3}$ This is the pre-eminent text on Parliament and it continues until this day, the $25^{\text {th }}$ edition having been issued in 2019. ${ }^{4}$ Another useful text - indicating the position of Parliament vis-a-vis Crown prerogatives in Victorian times - is that of Joseph Chitty Jr, A Treatise on the Law of Prerogatives of the Crown (1820). ${ }^{5}$

\section{ABOLISHING THE HOUSE OF LORDS}

The legal (and physical) concept of Parliament is that of two houses ${ }^{6}$ (that is, two chambers) assembled in one building (called parliament) which is styled (that is, called) the 'Parliament of the United Kingdom of Great Britain and Northern Ireland'.

- The first of these chambers - a lower chamber - is elected. This is the 'House of Commons' ( HC') being persons elected by the electorate (i.e. persons able to vote who do so).

\footnotetext{
${ }^{1}$ GS McBain, Modernising the Constitution - A Crown Act (2021) International Law Research, vol 10, no 1, pp 13-100. The article asserts that some 60 Acts relating to the Crown should be consolidated into 1 Crown Act.

${ }^{2}$ Ibid, Appendix B.

${ }^{3}$ TE May, A Treatise upon the Law, Privileges, Proceedings and Usage of Parliament (1844).

${ }^{4}$ D Natzler \& M Hutton, Erskine May's Treatise on the Law, Privileges, Proceedings and Usage of Parliament (25th ed, 2019). See also P Evans, Essays on the History of Parliamentary Procedure (2017).

${ }^{5} \mathrm{~J}$ Chitty (Jr), A Treatise on the Law of Prerogatives of the Crown (1820). There was only one edition.

${ }^{6}$ House' (Anglo-Saxon, hus) refers to the chambers (rooms) in the building. The word 'Parliament' refers to the building, albeit it is, often, used to also refer to the institution. ECS Wade \& GG Phillips, Constitutional Law (1st ed, 1931), p 107 'Parliament consists of two houses...'. Cf. May (in 1844), n 3, p 2 'The Imperial Parliament of the [UK] of [GB] and Ireland, is composed of the king or queen, and the three estates of the realm, viz. the Lords Spiritual, the Lords Temporal and the Commons.'
} 
- The second of these chambers - an upper chamber - is unelected. This is the 'House of Lords' ('HL') being persons appointed by the Crown (but, in reality, by the government, save for hereditary peers).

One contentious issue is whether the HL should be abolished. This is a political matter which is not further considered ${ }^{7}$ albeit the original purposive element of the HL has long ended. ${ }^{8}$ However, legally, abolition of the HL is relatively simple. Indeed, all that is needed is for legislation to provide that: 'The House of Lords in Parliament is abolished'. Cromwellian legislation so provided, the Commonwealth Act of $19^{\text {th }}$ March 1648/9 stating:

The Commons of England assembled in Parliament, finding by too long experience, that the House of Lords is useless and dangerous to the people of England to be continued, have thought fit to ordain and enact, and be it ordained and enacted by this present Parliament, and by the authority of the same, that from henceforth the House of Lords in Parliament, shall be and is hereby wholly abolished and taken away. (italics supplied)

As well as such a sentence, legislation expressly dealing with the HL (of which there is little) would need to be repealed. ${ }^{9}$ This, principally, comprises the following:

- House of Lords Precedence Act 1539. This regulates seating in the HL, in archaic form. ${ }^{10}$

- Union with Scotland Act 1706, art 25(6). This provides for the election of 16 Scots peers to the HL ${ }^{11}$ (art 23, which provides for the precedence of Scots peers, would not require to be repealed).

- Parliament Acts 1911 \& 1949. These provide for the non-consent of the HL in respect of money bills. Thus, the 1911 Act, s 1(1) states: 'If a money bill, having been passed by the [HC], and sent up to the [HL] at least one month before the end of the session, is not passed by the [HL] without amendment within one month after it is so sent up to that house, the Bill shall, unless the [HC] direct to the contrary, be presented to [HM] and become an Act of Parliament on the royal assent being signified, notwithstanding that the [HL] have not consented to the Bill.' The Act of 1949 amended the 1911 Act.

- House of Lords Act 1999. This removed the right of hereditary peers to sit in the HL, bar 92 hereditary peers. ${ }^{12}$

- House of Lords Reform Act 2014 \& House of Lords (Expulsion and Suspension) Act 2015. These deal with non- attendance, expulsion etc. in respect of the HL.

\footnotetext{
${ }^{7}$ That said, it may be noted that the HL, from its inception, has always been a place of privilege - one mainly reserved for the Royal family and their children (legitimate and otherwise); also retainers and others connected to them. Further, repeated attempts to modernise the HL over the centuries have failed and it remains excessively large. The retention of the HL has been subject to considerable criticism from all parties (mostly recently the SNP and the Labour Party).

${ }^{8}$ The HL (the chamber of the lords or peers) originated - from the Norman Conquest, at least - as an assembly of major landowners and other important dignatories (such as clerics) who assembled to advise the sovereign in person. The rationale for this was that such landowners held their land subject to military service (knight's service), in order to provide an army to the sovereign to defend the realm (even senior clerics, while obliged to provide other tenurial services, had military obligations at the outset of the Norman Conquest). By the time of Henry I (110035) knight's service was commuted, in most cases, into a military payment (escuage), enabling the sovereign to fund a professional army. Knight's service (and most other tenurial services) were abolished by the Tenures Abolition Act 1660 (extant).

${ }^{9}$ See $\mathrm{p} 83$ (schedule I, Pt 2). A Parliament Act should, also, provide that any ancillary or supplementary legislation required to be repealed (or amended) - as well as the abolition of any ancillary matters in respect of the abolition of the HL - may be set out in an SI.

${ }^{10}$ May (in 2019), n 4, p 134 'In practice these arrangements have been modified for the sake of convenience in debate on modern party lines...'. ${ }^{11}$ viz (recital of Act of Parliament of Scotland for settling Election of the [16] peers and [45] Members for Scotland). 'And whereas since the passing the said Act in the Parliament of Scotland for ratifying the said Articles of Union one other Act intituled Act settling the manner of electing the [16] peers and [45] members to represent Scotland in the Parliament of [GB] hath likewise passed in the said Parliament of Scotland at Edinburgh the [5 Feb 1707] the tenor whereof follows: Our Sovereign Lady considering that by the [22nd] Article of the Treaty of Union as the same is ratified by an Act passed in this Session of Parliament upon the [16 Jan 1706] it is provided that by virtue of the said Treaty of the peers of Scotland at the time of the Union, [16] shall be the number to sit and vote in the [HL] and [45] the number of the representatives of Scotland in the [HC] of the Parliament of [GB] and that the said [16] peers and [45] members in the [HC] be named and chosen in such manner as by a subsequent Act in this present session of Parliament in Scotland should be settled which Act is thereby declared to be as valid as if it were a part of and ingrossed in the said Treaty; therefore [HM] with advice and consent of the estates of Parliament statutes enacts and ordains that the said [16] peers who shall have right to sit in the House of Peers in the Parliament of [GB] on the part of Scotland by virtue of this Treaty shall be named by the said peers of Scotland whom they represent their heirs or successors to their dignities and honours out of their own number and that by open election and plurality of voices of the peers present and of the proxies for such as shall be absent the said proxies being peers and producing a mandate in writing duly signed before witnesses and both the constituent and proxy being qualified according to law declaring also that such peers as are absent being qualified as aforesaid may send to all such meetings lists of the peers whom they judge fittest validly signed by the said absent peers which shall be reckoned in the same manner as if the parties had been present and given in the said list. And in case of the death or legal incapacity of any of the said [16] peers that the aforesaid peers of Scotland shall nominate another of their own number in place of the said peer or peers in manner before and after mentioned. It is always hereby expressly provided and declared that none shall be capable to elect or be elected for any of the said estates but such as are [21] years of age complete.' (punctuation provided, to improve intelligibility).

${ }^{12}$ These include the offices of Earl Marshall (Duke of Norfolk) and the Lord Great Chamberlain (Marquess of Cholmondeley).
} 
- $\quad$ Lords Spiritual (Women) Act 2015. This applies where: (a) a vacancy arises among the Lords Spiritual in the HL in the 10 years beginning with the day on which this Act comes into force, (b) at the time the vacancy arises there is, at least, one eligible bishop who is a woman, and (c) the person otherwise entitled to fill the vacancy under the Bishoprics Act 1878, s 5 is a man.

If the HL were abolished what would not be required would be to change the reference to 'Parliament' in legislation - simply, that the same now refers to the HC. There are a few other (minor) legal consequences to any abolition of the HL.

- Impeachment. Theoretically, the legal process of impeachment still exists. That is, when the HC accuses a person of a criminal offence and the HL, then, acts as a court to deliver judgment. However, impeachment has fallen into desuetude (the last successful impeachment was in 1746) and an essential element was the presence of senior judges as members of the HL, to advise the other members of same, in order to effect the process of trial leading to judgment. As it is, with the creation of a Supreme Court, the latter no longer occurs and the HL is now, solely, a political body and not a judicial one. Thus, it (clearly) seems not to meet the requirements of human rights legislation. ${ }^{13}$ In any case, the modern judicial system is quite sufficient to try important political and other persons who, in ancient times, might otherwise have overawed an English court and prevented the course of justice being achieved. ${ }^{14}$ As it is, May (2019) succinctly states: 'The [HL's] jurisdiction in impeachments by the [HC] has fallen into disuse' ${ }^{15}$ Enough said.

- $\quad$ Peerage Claims. These are now (very) rare. ${ }^{16}$ Jurisdiction should pass to the High Court in any case - in order to secure the certainty of an impartial trial. Also, a right of appeal.

- $\quad$ Bills. A statutory instrument ('SI') (or legislation) should set out the submission process for bills - general, private (i.e. local and private) and hybrid - before Parliament - as well as in respect of delegated legislation (SI's) - in the absence of the HL. The opportunity should be taken to employ the same Parliamentary procedure for general, local and private bills - removing the complexity of the latter two (see also 22).

If the HL is abolished, the HC could (perhaps) occupy the upper chamber while Parliament is being repaired since legislation has never precluded the HC sitting in the HL chamber (or vice versa). ${ }^{17}$ As for the ceremonial opening of Parliament, little change would be needed. ${ }^{18}$

\section{ABOLISHING OSOLETE CROWN PREROGATIVES RELATING TO PARLIAMENT}

The Glorious Revolution of 1688 established, in fact, that the Crown was subject to Parliament. ${ }^{19}$ Indeed, that Parliament could choose (elect) the sovereign. This it did with the election of William of Orange and his wife Mary (1688-1702), the former sovereign - James II (1685-8) - being held by Parliament to have abdicated the throne by fleeing. ${ }^{20}$ Prior to this the Crown had a number of prerogatives in relation to Parliament. Subsequent thereto several of the same died out. Others still exist. However, many of these should now be abolished as obsolete. Further, the role of the sovereign, today, being only a formal (i.e. non executive) one, it is appropriate that other Crown prerogatives be abolished since the Crown is now subject to Parliament (and not the other way round). Thus, Chitty in (1820) remarked:

\footnotetext{
${ }^{13}$ Human Rights Act 1998, art 6(1) 'In the determination of his civil rights and obligations or of any criminal charge against him, everyone is entitled to a fair and public hearing within a reasonable time by an independent and impartial tribunal established by law.' (italics provided). See also GS McBain, Abolishing 'High Crimes and Misdemeanours' and the Criminal Processes of Impeachment and Attainder (2011) 85 Australian LJ, pp 871-2.

${ }^{14}$ The legal process of impeachment (and the high crimes and misdemeanours for which a person could be impeached) are dealt with in detail in McBain, $\mathrm{n} 13$.

${ }^{15}$ May (2019), n 4, p 210. It also states: 'Since the establishment of the Supreme Court, the sole remaining judicial function of the [HL] is in respect of peerage claims'. One would agree.

${ }^{16}$ See also May (2019), n 4, pp 210-1 (it should be noted that the decisions of the Committee for Privileges and Conduct are not judgments. Also, they are not binding in another claim). See also McBain, n 13, p 872.

${ }^{17}$ The HL and HC assemble in the former for the Queen's speech. In olden times they may have sat in one chamber, see May (in 1844), n 3 , $\mathrm{p}$ 18. Ibid, $\mathrm{p} 20$ 'They are separated, indeed, but in legislation they are practically one assembly, as much as if they sat in one chamber, and in the presence of each other, communicated their separate votes.' See also May (2019), n 4, p 3. 195 (HL chamber placed at the disposal of the HC from 1941-50).

${ }^{18}$ The HC are 'commanded' (this expression may not be appropriate today) to attend the HL in the chamber of the latter, which could still occur. However, in olden times, the HC and HL sat in one chamber (see n 17). Thus, the sovereign could sit in the HC to give her speech.

${ }^{19}$ See also May (in 1844), n 3, pp 2-3 'The power of Parliament over the Crown is distinctly affirmed by the statute law, and recognised as an important principle of the constitution.' Ibid, $\mathrm{p} 4$ 'Sir Thomas Smyth affirmed that 'the most high and absolute power of the realm of England consisteth in the Parliament". Ibid, p 31 'To adopt the words of Sir Edward Coke, the power of Parliament 'is so transcendent and absolute, that it cannot be confined, either for causes or persons, within any bounds.' The reference to Sir Thomas Smyth is to T Smith, De Republica Anglorum (written 1562-5, published 1583). The best modern edition is that of Mary Dewar (CUP. 1982). The reference to Sir Edward Coke is to E Coke, Institutes of the Laws of England (1641 ed), vol 4, p 36.

${ }^{20}$ This history is set out in the Bill of Rights 1688 (extant).
} 
With respect to their internal arrangements, Parliaments are, by the constitution of the country, and, indeed, their nature requires that they should be, distinct from, and independent of, the Crown. ${ }^{21}$

Presently existing Crown prerogatives (privileges) over Parliament - save for those in respect of the assembly of Parliament (for which see 5-10) - comprise the following: ${ }^{22}$

\section{(a) Crown Prerogative to Approve the Speakers of the HC or HL}

The historical position in respect of the HL and the HC was noted by Chitty (in 1820):

The Speaker of the [HL] is the Lord Chancellor, or keeper of the king's great seal, or any other person appointed by the king's commission; and if none be so appointed, the [HL] it is said, may elect one. The Speaker of the [HC] is chosen by the house; but must, it seems, be approved by the king. ${ }^{23}$

For his part, May (in 1844) stated (in respect of the speaker of the HC):

[after the Lord Chancellor addresses both Houses of Parliament, on their being convened he shall state]: 'that [HM] will, as soon as the members of both houses shall be sworn, declare the causes of her calling this Parliament; and it being necessary a speaker of the $[\mathrm{HC}]$ should be first chosen, that you, gentlemen of the [HC], repair to the place where you are to sit, and there proceed to the appointment of some proper person to be your speaker; and that you present such person whom you shall so choose here, tomorrow (at an hour stated), for [HM's] royal approbation '24 (italics supplied).

In relation to the present position, May (in 2019) states that, after the election of a speaker by the HC:

the speaker elect takes the chair and awaits the arrival of Black Rod from the Lords Commissioners. When that officer has delivered the message, the speaker elect, accompanied by the clerk and followed by the members of the house, goes up to the [HL] and acquaints the Lords Commissioners, 'That in obedience to [HM's] command, [HM's] most faithful commons have, in the exercise of their undoubted right and privileges, proceeded to the election of a speaker and that their choice has fallen upon myself. I therefore present myself to your Lordship's bar and submit myself with all humility to [HM's] gracious approbation.' In reply, the presiding commissioner assures the speaker elect of [HM's] sense of their sufficiency, and 'that [HM] most readily approves and confirms [the speaker elect] as the speaker. ${ }^{25}$

Today, the speaker of the HL is not the Lord Chancellor but (since 2006) the Lord Speaker. ${ }^{26}$ Further - given the formal role of the sovereign, the division of constitutional powers and the supremacy of Parliament - it would not seem appropriate for the sovereign to interfere in the appointment of either the:

- $\quad$ Speaker of the HC; or the

- $\quad$ Lord Speaker of the HL.

Thus, this Crown prerogative - which is obsolete in practice (since there is no interference) - should be abolished. Today, both speakers should be chosen by the relevant house of Parliament without input from the Crown.

In conclusion, any Crown prerogative to appoint (or to approve the appointment of) the speaker of the HC, or the Lord Speaker of the HL, should be abolished.

\section{(b) Crown Prerogative to Confirm the Privileges of the HC}

May (in 1844) noted that:

Some privileges rest solely upon the law and custom of Parliament, while others have been defined by statute. Upon these grounds alone, all privileges whatever are founded. The lords have ever enjoyed them, simply because 'they have place and voice in Parliament', but a practice has obtained with the commons [i.e. the HC], that would appear

\footnotetext{
${ }^{21}$ Chitty, n 5, p 73.

${ }^{22}$ It may be that there are more Crown prerogatives relating to Parliament existing. However, a review of May from 1844 would suggest that any, if they exist, are now obsolete/defunct.

${ }^{23}$ Chitty, n 5, p 74. Crown approval of the HC Speaker dates, it seems, at least, from 1399 (the first HC Speaker is said to be Sir Peter de la Mare in 1377), see J Hatsell, Precedents of Proceedings in the House of Commons (2nd ed, 1785), vol 2, p 153. See also Coke, n 19, vol 4, p 8. For the election of a speaker in 1504, see N Pronay \& J Taylor, Parliamentary Texts of the Later Middle Ages (1980), pp 197-201.

${ }^{24}$ May (in 1844), n 3, p 134. See also pp 34, 136-9. It was possible for the sovereign to refuse approbation (exercised in the case of Sir Edward Seymour in 1678). Ibid, p 139. Also, Hatsell (in 1785), n 23, vol 2, pp 156, 159. For the duties of the Speakers in 1844, see, Ibid, pp 152-4. EW Ridges, Constitutional Law of England (1934) ( $5^{\text {th }}$ ed, 1934 ed. AB Keith), p 44 noted that the Crown's approval of the speaker was 'since 1679 purely formal.'

${ }^{25}$ May (2019), n 4, p 172. Also, p 57. As to the Lord Speaker, Ibid, p 70 'The result of the election is subject to the approval of the Queen. If the house passes a motion for an address to [HM] seeking the Lord Speaker's removal from office, the Lord Speaker shall be deemed to have resigned.'

${ }^{26} \mathrm{Ibid}, \mathrm{p} 70$.
} 
to submit their privileges to the royal favour. At the commencement of every Parliament since the $6^{\text {th }}$ of Henry 8 [i.e. 1514], it has been the custom for the speaker,

'In the name, and on the behalf of the commons, to lay claim by humble petition, to their ancient and undoubted rights and privileges; and especially to freedom from arrest and molestation for their persons, servants, and estates, ${ }^{27}$ to freedom of speech in debate; and to free access to [HM] whenever occasion may require it; and to the most favourable construction of all their proceedings. ${ }^{28}$

To which the Lord Chancellor replies, that

'[HM] most readily confirms all the rights and privileges which have ever been granted to or conferred upon the commons, by [HM] or any of her royal predecessors.'

The influence of the Crown in regard to the privileges of the commons is further acknowledged by the report of the speaker to the house, 'that their privileges have been confirmed in as full and ample a manner as they have been heretofore granted or allowed by [HM] or any of her royal predecessors.' This custom probably originated in the ancient practice of confirming laws in Parliament, that were already in force, by petitions from the commons, to which the assent of the king was given with the advice and consent of the lords. In Atwyll's case, 17 Edw 4 [i.e. in 1477], the petition of the commons to the king states that their

'liberties and franchises your highness to the lieges, called by your authority royal to this your High Court of Parliament, for the shires, cities, burghs, and five ports of this realm, by your authority royal, at commencement of this Parliament, graciously have ratified and confirmed to us, your said commons, now assembled by your said royal commandment in this your said present Parliament.'

But whatever may have been the origin and cause of this custom, and however great the concession to the Crown may appear, the privileges of the commons are nevertheless independent of the Crown, and are enjoyed irrespective of their petition. Some have been confirmed by statute, and are, therefore, beyond the control either of the Crown or of any other power but Parliament; while others, have been limited or even abolished by statute, cannot be granted by the Crown.' ${ }^{29}$ (underlining supplied)

Today, the underlined words in the last paragraph of the above are especially significant and - given the formal role of the sovereign and the supremacy of Parliament - such a confirmation is neither necessary nor appropriate. ${ }^{30}$ Thus, any such petition (and confirmation) should be abolished.

- In any case, as to these 4 asserted privileges, 2 of them (freedom of speech and freedom of arrest) are contained in legislation $^{31}$ (thus, a prayer is no longer required). And, the other 2 (freedom of access and favourable construction) are courtesies - not privileges as such. They are, also, obsolete (se 17).

In conclusion, any Crown prerogative to confirm (or to require the confirmation of) the privileges of the HC should be abolished.

\section{(c) Crown Prerogative to Attend Parliamentary Debates}

With regard to the historical position, Chitty (in 1820) stated:

The king has...the undoubted right to be present in the [HL] during the debates, without going in state, or interfering in the proceedings. Charles the Second [1660-85], and several of his successors, frequently did so; but from the accession of George the First [1714-27] to the present time, the practice has been, and perhaps wisely, discontinued. ${ }^{32}$

For his part, May (in 1844) stated:

The queen is always supposed to be present in the High Court in Parliament, by the same constitutional principle which recognises her presence in other courts: but she can only take part in its proceedings by means which are acknowledged to be consistent with the Parliamentary prerogatives of the Crown, and the entire freedom of the debates and proceedings of Parliament. She may be present in the [HL], at any time, during the deliberations of that

\footnotetext{
${ }^{27}$ See Hatsell (in 1785), n 23, vol 2, pp 164-5. The privilege of freedom from arrest has been much curtailed in any case, see $\mathbf{1 6 .}$

${ }^{28}$ As May (in 1844), n 3, p 47 noted, 'most favourable construction' was never a privilege as such: 'It is not a constitutional right, but a personal courtesy... The occasions for this courtesy are also limited; as by the law and custom of Parliament the queen cannot take notice of anything said or done in the house [i.e. the HC], but by the report of the house itself.' Hatsell (in 1785), n 23, vol 2, p 163 suggested that the prayer first arose in the first year of Henry IV [i.e. 1399]. For the form of protestation in 1504, see Pronay, n 23 , p 45.

${ }^{29}$ May (in 1844), n 3, pp 44-6. See also pp 137-8. See also Coke, n 19, vol 4, p 8.

${ }^{30}$ For the position today, see May (in 2019), n 4, pp 57, 172 \& 241-52.

${ }^{31}$ See 15-6. GFM Campion, An Introduction to the Procedure of the House of Commons (1929), p 40 thought that these privileges were claimed after 1541 (not 1514, see text). See also J Baker, The Oxford History of the Laws of England (2003), vol 6 (1483-1558), pp 84-5.

${ }^{32}$ Chitty, n 5, p 74. See also Hatsell (in 1785), n 23, vol 2, p 265 'nothing of that sort is done at present.' WR Anson, The Law and Custom of the Constitution (1922), vol 1, pp 331-2 mentions Charles I (on 4 January 1642) entering the HC during debate.
} 
house, where the cloth of estate is; but she may not be concerned in any of its proceedings, except when she comes for the exercise of her prerogatives. Charles the $2^{\text {nd }}$ [1660-85], and his immediate successors, were accustomed to be present during the debates of the [HL]; but this questionable practice, which might be used to overawe that assembly, and influence their debates, has wisely been discontinued since the accession of George I [1714-27]. And according to the practice of modern times, the Queen is never personally present in Parliament, except on its opening and prorogation; and occasionally for the purpose of giving the royal assent to bills during a session. ${ }^{33}$

There is no good reason to preserve this Crown prerogative today, given the separation of powers. Also, it is important that Parliament not be influenced (overawed) by the Crown when conducting its business. ${ }^{34}$

In conclusion, any Crown prerogative of the sovereign to attend (in person) any Parliamentary debate (whether of the HC or HL) should be abolished.

\section{(d) Crown Prerogative to Appoint the Clerk of the Parliaments and other Parliamentary Officers}

This is reflected in legislation, see 21(e). For the reasons given there, this prerogative should be abolished.

In conclusion, any Crown prerogative to appoint the Clerk of the Parliaments - as well as any other Parliamentary officers should be abolished.

\section{(e) Crown Prerogative to Licence the Use of Proxies in the HL}

Chitty (writing in 1820) noted:

in order to make a proxy [in the HL], which the members of the upper House can only effectually and legally do, the king's licence is in strictness necessary. Though, it is said, that this is now so much a mere form that the licence may be presumed. ${ }^{35}$

For his part, May (in 1844) stated:

In the lords [HL]...not only those peers who are present may vote in a division, but, on certain questions, absent peers are entitled to vote by proxy, and their votes are numbered with the rest; the joint majority of votes and proxies being decisive of the question. ${ }^{36}$

Today (assuming the HL is not abolished), any Crown prerogative to licence the use of a proxy for a member of the HL is not appropriate and should be abolished. Further, no member of the HL should be able to represent him (or her) self in the HL by means of a proxy. This, also, would not seem appropriate in modern times. As it is, in 1867, it was recommended by a committee of the HL that proxies be discontinued and, on 31 March 1868, the HL agreed to a standing order to carry out the recommendation..$^{37}$ It also seems that the Crown's prerogative to licence proxies had been forgotten by $1810 .{ }^{38}$

In conclusion, any Crown prerogative to licence a member of the HL to use a proxy should be abolished. Any privilege of a HL member to appoint a proxy should, also, be abolished.

\section{(f) Statutory Crown Prerogative to Fine (Amerce) ${ }^{39}$ a member of the HC (or HL) for Non-Attendance}

The Summons to Parliament Act 1382 (every one shall obey his summons to Parliament) states:

The king doth will and command, and it is assented in the Parliament by the prelates, lords, and commons, that all and singular persons and commonalties which from henceforth shall have the summons of the Parliament, shall come from henceforth to the Parliaments, in the manner as they are bound to do, and have been accustomed within the realm of England of old times.

And if any person of the same realm, which from henceforth shall have the said summons, be he archbishop, bishop, abbot, prior, duke, earl, baron, banneret, knight of the shire, citizen of city, burgess of borough, or other singular person or commonalty, do absent himself, and come not at the said summons, except he may reasonably and honestly

\footnotetext{
${ }^{33}$ May (in 1844), n 3, p 259.

${ }^{34}$ May (2019), n 4, p 252 'the [HC] has long established the principle that the sovereign may not, even as a spectator, attend its debates...No principle exists restricting the sovereign's attendance at debates in the [HL].' As to the latter, the statement is (technically) correct. However, the practice has been discontinued for 300 years or so (since George I) and there seems no good reason to revive the same now.

${ }^{35}$ Chitty, n 5, p 74. See also Coke, n 19, vol 4, p 12. Also, G Bowyer, Commentaries on the Constitutional Law (1846), pp 85-6.

${ }^{36}$ May (in 1844), n 3, pp 219-20. He also noted the various rules and restrictions on the use of proxies. See also Ibid, p 147.

${ }^{37}$ LO Pike, A Constitutional History of the House of Lords (1894), p 245 'the practice of calling for proxies on a division shall be discontinued, and that two days' notice be given for any motion for the suspension of this standing order'. Pike, usefully, sets out the history re proxies in the HL.

${ }^{38}$ Ibid, p 244.

${ }^{39}$ The old word was 'amercement' since the level of the fine was at the mercy of the Crown.
} 
excuse him to our lord the king, he shall be amerced, and otherwise punished, according as of old times hath been used to be done within the said realm in the said case. ${ }^{40}$

This legislation enables the sovereign to fine those who do not obey the summons to Parliament (and an Act of 1514 (rep) ${ }^{41}$ enabled the speaker of the HC to fine those who depart from Parliament, when sitting, without licence).

- However, today, the speaker of the $\mathrm{HC}$ would be a more appropriate person than the Crown to undertake the same (as well as the Lord Speaker, in the case of the HL), if fining is required;

- $\quad$ As it is, Hatsell (in 1785) inveighed against MPs refusing to turn up, but admitted that there was little (nothing) that could be done (the procedure of the sarjeant at arms taking them into custody being obsolete) ${ }^{42}$

Also, fining (in general) ended by $1666 .^{43}$

In conclusion, this Crown prerogative to fine (amerce) a member of the HC (or the HL) for non-attendance should be abolished. Such a power to fine should lie - if required - with the Speaker of the HC (or the Lord Speaker of the HL). The Summons to Parliament Act 1382 should, also, be repealed.

\section{(g) Crown Prerogative to add Members to the HL or HC}

In respect of the historical position, Chitty (writing in 1820) stated:

It is in the power of the Crown to add any number of members to the House of Peers [i.e. the HL], by raising individuals to the English peerage; ${ }^{44}$ but it may perhaps be doubtful where the king has it in his power to increase the number of members in the lower house of Parliament, by empowering an unrepresented town to elect, and send members to Parliament. It seems clear that from the time of Edward 4 [1461-83], until the reign of Charles 2 [166085], both inclusive, our kings used frequently to assume and exercise this right.

The last time it is known to have been exercised was in the 29 Charles 2 [i.e. 1677] who gave this privilege to Newark; and on the legality of the grant being then questioned for the first time in the [HC], it was acknowledged by a majority of 125 members to 73 . The reason why it is doubted at the present day is, that by the Scotch and Irish Acts of Union with England, the representatives to be sent by the former two countries to the united Parliament, are limited to a certain specified number; and if the king could add to the number of the English members, the proportion would be unfair in favour of England, to the prejudice of Scotland and Ireland: consequently it is said that this prerogative is abrogated. But it is submitted that the king cannot be deprived of a prerogative, except by the express words of a statute, and the Acts of Union contain no provision on the subject. The argument used against this prerogative of the Crown, seems to prove too much to be tenable. Would it not prevent [HM] from creating or nominating peers to sit in the upper house? A right which has never been disputed. ${ }^{45}$

Any Crown prerogative to add to the number of MP's should be abolished as being inappropriate to the supremacy of Parliament (as well as an unwarranted interference with democracy). The same should also apply to the HL (assuming it is not abolished). Thus, the power to create (or nominate) peers, today, should only be exercised by the PM and reviewed by the House of Lords Appointments Commission. That is, the sovereign should no longer have the power, in person, to create (or nominate) peers through exercising her individual choice.

In conclusion, any prerogative of the sovereign in person to add to the members of the HC (or the HL) should be abolished. Further, the latter should be statutory.

\footnotetext{
${ }^{40}$ May (in 1844), n 3, pp 147-50. See also Coke, n 19, vol 4, p 43. Also, Pronay, n 23, pp 44-7.

${ }^{41} 6$ Hen 8 c 16 (1514, rep 1993) (knights, citizens, or burgesses shall not depart from Parliament until the session be ended, without licence of the speaker of the $\mathrm{HC}$; on forfeiture of their wages).

${ }^{42}$ Hatsell (in 1785), n 23, vol 2, pp 68-72 'It has not been customary of late years, to enforce the call of the [HC], by taking members who did not attend, into the custody of the sarjeant.' See, for peers, T Gurdon, The History of the High Court of Parliament (1731), vol 2, pp 349-50.

${ }^{43}$ CR Munro, Studies in Constitutional Law (1999), p 234 'The [HL], as a court of record, has the power to impose fines on offenders. The $[\mathrm{HC}]$ in the sixteenth and seventeenth centuries used to impose fines, but has not since 1666, and it later was denied that the house possesses such a power.' See $R v$ Pitt \& Mead (1762) 3 Burr 1335 per Lord Mansfield. Also, FW Maitland, The Constitutional History of England (1950), p 377 (the power of the HL to fine does not seem to have been questioned).

${ }^{44}$ May (2019), n 4, p 5 'All titles of honour are the gift of the Crown, and thus all 'lords temporal' in the upper house have been created by royal prerogative, and their number may be increased at pleasure.'

${ }^{45}$ Chitty, n 5, pp 67-8. See also Maitland, n 43, p 290.
} 


\section{(h) Crown Prerogative to Originate Acts of Grace}

The Crown had (and, technically, still has) the prerogative to originate an Act of Grace ${ }^{46}$ - as opposed to Parliament originating the same. ${ }^{47}$ It is asserted such a prerogative is obsolete and not appropriate in modern times. Thus, this Crown prerogative should be abolished. Only Parliament should originate legislation - including any general pardon.

In conclusion, any Crown prerogative to originate an Act of Grace should be abolished.

\section{(i) Crown Prerogative to Appoint the Sarjeant-at-Arms of the HC and HL and Black Rod}

The Crown has the prerogative to appoint the sarjeant-at-arms of the HL and the HC. Thus, May (in 1844) noted:

The serjeant-at-arms [of the HL] is also appointed by the Crown. He attends the lord chancellor with the mace, and executes the orders of the house for the apprehension of delinquents, and all warrants of attachment... ${ }^{48}$

Also,

The sarjeant-at-arms [of the $\mathrm{HC}$ ]...is appointed by the Crown, under a warrant from the lord chamberlain, and by patent under the great seal, 'to attend upon [HM's] person when there is no Parliament; and, at the time of every Parliament, to attend upon the Speaker of the [HC].' But after his appointment he is the servant of the house, and may be removed for misconduct.... ${ }^{49}$

As for Black Rod, who serves in the HL, May (in 1844) noted:

The gentleman usher of the black rod is appointed by letters patent from the Crown, and he, or his deputy, the yeoman usher, is sent to desire the attendance of the Commons in the House of Peers [i.e. the HL] when the royal assent is given to bills of the Queen or the lords commissioners and on other occasions. He executes orders for the commitment of parties guilty of breaches of privilege and contempt, and assists at the introduction of peers, and other ceremonies. ${ }^{50}$

In 1971, the office of sarjeant-at-arms in the HL was merged with that of Black Rod. ${ }^{51}$ In the HC, the right of the HC to appoint the sarjeant-at-arms was restored in 1962, although the same remains (technically) in the gift of the sovereign. ${ }^{52}$

- Today - given the supremacy of Parliament and the formal role of the sovereign as well as these persons being servants of Parliament in reality - it would seem appropriate they be appointed by the HC and the HL (assuming the $\mathrm{HL}$ is not abolished).

- The same should apply to any other officer of the HC or HL (for the Clerk of the Crown in Chancery, see (j)).

In conclusion, any Crown prerogative to appoint the sarjeants-at-arms of the HC or HL or Black Rod (or any other officer) of the HC or the HL - should be abolished.

\section{(j) Crown Prerogative to appoint the Clerk of the Crown in Chancery}

May (2019) notes:

The clerk of the Crown in Chancery (who is also the permanent Secretary to the Ministry of Justice) is appointed under the royal sign manual. The Clerk of the Crown and their [his/her] deputy are officers of both houses. The Clerk of the Crown in Chancery has responsibilities in the [HL] relating to the issue of writs of summons and for the preparation of letters patent creating a peerage, and in the Commons for issuing writs for Parliamentary elections,

\footnotetext{
${ }^{46}$ Acts of Grace comprised a general pardon (and, usually, of oblivion) issued by the Crown (although Cromwell did the same during the Protectorate, see Comwell's Act of Grace of 1654 to the people of Scotland). Acts of Grace were, sometimes, passed after civil rebellions, such as after the Jacobite risings of 1715 and 1745. See G Jacob, A New Law Dictionary (1st ed, 1729)(Grace) 'Acts of Parliament for a general and free pardon, are called Acts of Grace. 7 Geo I St 1 c 29 [1720, general pardon] etc'.

${ }^{47}$ May (in 1844), n 3, p 271 'A bill for a general pardon is an exception to the usual mode of passing bills; it begins with the Crown, and is read once only in each house, after which it receives the royal assent in the ordinary form.'

${ }^{48}$ Ibid, p 157.

${ }^{49}$ Ibid, pp 162.

${ }^{50}$ Ibid, p 156-7.

${ }^{51}$ May (2019), n 4, p 124 notes: '[Black Rod] is appointed by the Crown by letters patent under the great seal. Black Rod, or the deputy, the yeoman usher, is on duty when the house [HL] is sitting, and acts as the messenger of the sovereign whenever the attendance of the commons $[\mathrm{HC}]$ is required. Black Rod is responsible for administrative arrangements whenever the sovereign is in Parliament. Black Rod also acts as Secretary to the Lord Great Chamberlain and as such is responsible for certain ceremonial duties and arrangements, including daily management of the sovereign's residual estate in the Palace [of Westminster].... Since 1971, Black Rod has also held the office of sarjeant at arms and is appointed to that office by the Crown by letters patent under the great seal. Black Rod attends the Lord Speaker in the capacity of serjeant at arms.'

${ }^{52} \mathrm{Ibid}, \mathrm{p} 115$ 'The appointment of the sarjeant at arms is in the gift of the Queen, under a warrant from the Lord Chamberlain, and by patent under the great seal, 'to attend upon [HM's] person when there is no Parliament; and at the time of every Parliament, to attend upon the speaker of the $[\mathrm{HC}]$ '; but after appointment the sarjeant is the servant of the House and may be removed for misconduct.'
} 
directed to the returning officers for all constituencies in [GB]. It is also the Clerk of the Crown's duty to prepare certain documents (commissions for royal assent and prorogation, commissions for the opening of Parliament, Deputy Speakers' commissions) by which the sovereign's commands are conveyed to one or other house or to Parliament. The Clerk of the Crown or their [his/her] deputy also takes part in the signification by commission of royal assent to Acts of Parliament, and in the introduction of a Clerk of the Parliaments. ${ }^{53}$

Since the Clerk is appointed by the sovereign - and, yet, is an officer of Parliament - there is a conflict of interest between the two (who to obey?). The clerk is also, only nominally in practice, a servant of the sovereign since he/she is the permanent secretary to the Ministry of Justice (who exercises a political function). Thus, it would seem appropriate that, today - in respect of the Parliamentary functions the clerk performs - that such be appointed by the Clerk of the Parliaments. And, that this appointment be approved by Parliament. Also, many of the Clerk of Chancery's administrative functions are stuck in a time warp. They should be modernised - to save time, money and cost (as well as to be more transparent). Thus:

HL - Issue of Writs of Summons. A short, standardised form of proclamation, should be employed.

HL - Issue of Letters Patent creating a Peerage. Same.

HC - Issue of Writs for Parliamentary elections. Same.

HC - Issue of Commissions for Royal Assent, prorogation, the opening of Parliament and Deputy Speakers. In the case of the royal assent - if still required - this should be automatically provided for in legislation. In the case of prorogation and the opening of Parliament - proclamations as above. In the case of deputy speakers, commissions would be unnecessary if the speaker is not appointed by the Crown;

HC - Signification by commission of Royal Assent. Introduction of a Clerk of the Parliament. Royal assent by commission is not required if royal assent is automatically provided for by legislation (see above). The introduction of a Clerk of the Parliament is, also, not necessary.

In conclusion, the Crown prerogative to appoint the Clerk of the Crown in Chancery (and any deputy) should be abolished. Instead, the same should be appointed by the Clerk of the Parliament (with confirmation by Parliament, if necessary). Further - nodding to the fact that we are now in the $21^{\text {st }}$ century - writs should be replaced by proclamations (capable of electronic transmission). In all these cases, it may be noted, the role of the sovereign is only a formality today - she is not exercising any executive power in person.

In conclusion, any Crown prerogative to appoint the Clerk of the Crown in Chancery should be abolished - thus, recognising that the same is a servant of Parliament (and of government) in reality.

\section{(k) Crown Prerogative to Communicate with Parliament Orally}

When the sovereign attends Parliament in person she addresses the same (without any immediate reply). The sovereign also communicates by way of commission (via her Lords Commissioners who are 'stand-ins' for the Lord Chancellor, who undertook such tasks in earlier times). These are formal (i.e. ceremonial) occasions, as noted by May (in 1844). ${ }^{54}$ Apart from these, the Crown can also communicate with the HC and/or the HL by means of messages under: (i) the great seal; or (ii) the royal sign manual (i.e. in writing with her signature). Thus, May (in 1844) stated:

The mode of communication next in importance is by a written message under the royal sign manual, to either house singly, or to both houses separately...The subjects of such messages are usually communications in regard to important public events which require the attention of Parliament; the prerogatives or property of the Crown; provision for the royal family; and various matters in which the executive seeks for pecuniary aid from Parliament. They may be regarded, in short, as additions to the royal speech, at the commencement of the session, submitting other matters to the deliberation of Parliament, besides the causes of summons previously declared. ${ }^{55}$

However, it was (and is) possible for the sovereign to communicate with Parliament orally (verbally). Thus, May (in 1844) stated:

Another form of communication from the Crown to either house of Parliament, is in the nature of a verbal message delivered, by command, by a minister of the Crown to the house of which he is a member. This communication is used whenever a member of either house is arrested for any crime by order of the Crown; and when the privileges of Parliament require that the house should be informed of the cause for which their member is imprisoned, and

\footnotetext{
${ }^{53}$ Ibid, pp 127-8.

${ }^{54}$ May (in 1844), n 3, p 260 'The most important modes by which the Crown communicates with the Parliament, are exemplified on those occasions whe [HM] is present in person or by commission in the [HL], to open or prorogue Parliament; and when a royal speech is delivered to both houses. In giving the royal assent to bills in person or by commission, the communication of the Crown with the Parliament is of an equally solemn character. On these occasions the whole Parliament is assembled in one chamber, and the Crown is in immediate and direct contact with the three estates of the realm.'

${ }^{55}$ Ibid, pp 260-1.
} 
detained for service in Parliament...In the same manner, when members have been placed under arrest in order to be tried by military courts martial, the secretary-at-war, or some other minister of the Crown, being a member, informs the house that he has been commanded to acquaint them of the arrest of their member and its cause. Communications of the latter description are made when members have been placed under arrest, to be tried by naval courts martial, but in these cases they are not in the form of a royal message, but are communications from the lord high admiral or lords commissioners of the admiralty, by whom the warrants are issued for taking the members into custody; and copies of the warrants are, at the same time, laid before the house.... ${ }^{56}$ (underlining supplied)

When the house are informed, by command of the Crown, of the arrest of a member to be tried by a military court martial, they immediately resolve upon an address of thanks to [HM] 'for her tender regard to the privileges of this house'. And in all cases in which the arrest of a member for a criminal offence is communicated, an address of thanks is voted in answer. But as the arrest of a member to be tried by a naval court martial does not proceed immediately from the Crown, and the communication is only made from the lords to the admiralty, no address is resolved upon to this indirect form of message..$^{57}$

Today, the need for the sovereign to communicate orally with Parliament - other than when physically present in Parliament and addressing the same - no longer exists. ${ }^{58}$ Further, this form of communication is fraught with uncertainty (and the potential for mis-communication). Thus, any Crown prerogative to utilise the same should be abolished - including orally proroguing or dissolving Parliament (see 9 and 10). It may be noted that May (2019) - appropriately - scarcely refers to oral messages since, in practice, communications today are in writing..$^{59}$

In conclusion, any Crown prerogative for the sovereign to communicate orally with Parliament - other than when formally addressing the same in person - should be abolished, as unnecessary and fraught with uncertainty. This includes the sovereign orally proroguing and dissolving Parliament.

\section{(l) Crown Prerogative to recommend or consent to Bills of Parliament}

The Crown may communicate with Parliament in various ways (see (k)). There are also other modes as mentioned by May (in 1844) viz.

The other modes of communicating with Parliament are by the royal 'pleasure', 'recommendation', or 'consent', being signified. [The Queen's pleasure is then discussed]. ${ }^{60}$

The royal recommendation [italics supplied] is signified to the Commons by a minister, on motions for receiving petitions; for the introduction of bills, or on the offer of other motions involving any grant of money not included in the annual estimates, whether such grant is to be made in the committee of supply, or any other committee; or which would have the effect of releasing or compounding any sum of money owed to the Crown.

The royal consent [italics supplied] is given to motions for bills, or amendments to bills, or to bills in any of their stages, which concern the royal prerogatives, the hereditary revenues, or personal property or interests of the Crown or [the] duchy of Cornwall. The mode of communicating the recommendation and consent is the same; but the former is given at the very commencement of a proceeding, and must precede all grants of money; while the latter may be given at any time during the progress of a bill, in which the consent of the Crown is required.

Another form of communication, similar in principle to the last, is when the Crown 'places its interests at the disposal of Parliament,' which is signified in the same manner, by a minister of the Crown. ${ }^{61}$

Today - given the supremacy of Parliament and the formal role of sovereign - as well as the democratic society in which the UK now exists - it would not seem appropriate for the Crown (that is, the sovereign in person) or the duke of Cornwall (when not the sovereign) to seek to influence the content of bills of Parliament. Thus, it is suggested the following non-statutory forms of royal influence be abolished viz.

\footnotetext{
${ }^{56}$ Ibid, pp 262-3.

${ }^{57}$ Ibid, p 265.

${ }^{58}$ As May (2019), n 4, p 194 noted generally 'A message is the most simple mode of communication'. See also Ibid, ch 9.

${ }^{59}$ Ibid, p 186. AB Keith, The King and the Imperial Crown (1936), p 69. He referred to various actions by word of mouth by the sovereign. However, most of those were obsolete even then.

${ }^{60}$ May (in 1844), n 3, p 263 'The Queen's pleasure is signified at the commencement of each Parliament, by the lord chancellor, that the commons should elect a speaker; and when a vacancy in the office of speaker occurs in the middle of a Parliament, a communication of the same nature is made by a minister in the house. [HM's] pleasure is also signified for the attendance of the commons in the House of Peers [i.e. the HL]; in regard to the times at which she appoints to be attended with addresses; and concerning matters personal affecting the interests of the royal family. At the end of a session, also, the royal pleasure is signified, by the lord chancellor, that Parliament should be prorogued. Under this head may likewise be included the approbation of the speaker elect, signified by the lord chancellor.' See also May (2019), n 4, p 187.

${ }^{61}$ Ibid, pp 263-4.
} 
- royal recommendation;

- $\quad$ royal consent (which is different from the royal assent); and

- $\quad$ the Crown placing 'its interests at the disposal of Parliament.'

May (2019), states:

Royal Recommendation. 'The Queen's recommendation is a technical form of great importance in financial procedure, as it is required in the Commons to sanction the proposal of a charge upon public funds and thus reserves the initiation of expenditure to the Crown, as embodied in the government of the day. The Queen's recommendation is required for motions which involve any public expenditure or grant of money not included in the annual estimates, or which would have the effect of releasing or compounding any sum of money owing to the Crown. The Queen's recommendation is normally notified by the Office of Parliamentary Counsel on behalf of a responsible minister to the Commons Public Bill Office when such a motion is tabled. The fact that the recommendation has been signified is entered on the Order Paper on which appears the notice of the motion to which it relates.' ${ }^{6}$

Queen's Consent to Bills. 'Bills affecting the prerogative (being powers exercisable by the sovereign for the performance of constitutional duties) on the one hand, or hereditary revenues, personal property or interests of the Crown, the duchy of Lancaster or the duchy of Cornwall on the other, require the signification of the Queen's consent in both houses before they are passed. When the Prince of Wales is of age, his own consent as Duke of Cornwall is given.'

The problem with the above matters is that they affect the supremacy of Parliament and they fail to reflect the formal role of the sovereign today (thus, the recommendation or consent reflects the advice of the royal households, as opposed to any personal decision, after reflection, by the sovereign acting in an executive capacity). Further, the latter Crown prerogative (the sovereign's consent) is a relatively new invention. It does not appear among the Crown prerogatives in earlier times (as opposed to royal assent). It is, also, a 'creeping' prerogative since May (in 1844) never mentioned, for example, the duchy of Lancaster (which the sovereign holds, at least, nominally - in a private capacity). Also, the exercise of this prerogative by the duchy (Duke) of Cornwall can only occur by way of franchise (since it is the transfer (alienation) of a Crown prerogative). Yet this same is reflected in no charter granted by the Crown to the duchy; nor in legislation - it has crept onto the scene in recent times. ${ }^{63}$ Hatsell (in 1785) makes no mention of any rights of the duchy of Cornwall in this respect. ${ }^{64}$

- Suffice to say that this private means of altering bills is more redolent of times prior to 1688 when sovereigns sought to amend legislation - or prevent such as was contrary to their interests coming to pass. It does not belong to a modern, democratic, society. Nor does it reflect the process since the time of Henry VI (1422-71) that bills are made and passed by Parliament to which the sovereign can only say 'yes' (i.e. assent) or ' $n o$ ' (dissent). ${ }^{65}$

- Indeed, if preliminary consent of the sovereign is now required, how would major constitutional reforms - such as reflected in the Petition of Right 1627 - have ever come to pass?

Thus, investigation is needed as the origins of this prerogative or whether (as with the issue concerning the taxation of the duchy of Cornwall) the source of it relates to no statute (nor the franchise of a Crown prerogative) but rather, to Parliament's civil servants conceding the same.

In conclusion, any Crown prerogative to communicate with Parliament by way of: (a) royal recommendation; (b) royal consent; or (c) the placing by the Crown of its interests at the disposal of Parliament, should be abolished.

In conclusion the above Crown prerogatives relating to Parliament should be abolished. They are out of date and they comprise (today) inappropriate and unnecessary interference by the Crown in the operation of Parliament. Especially, in light of the supremacy of Parliament today - in fact and law.

\footnotetext{
${ }^{62}$ Ibid, pp 187-8.

${ }^{63}$ It may be noted that the citations given by May (2019), n 4, p 187 are not earlier than the 1950's. For charters of the duchy, see GS McBain, Time to Abolish the Duchy of Cornwall? (2013) Rev. of European Studies, vol 5, no 5, pp 40-58.

${ }^{64}$ Hatsell (in 1785), n 23, p 254. It may be argued that the sovereign has some right when he/she holds the duchy of Cornwall qua sovereign, but not when there is a separate duke, as at present.

${ }^{65}$ See also May (in 1844), n 3, p 270 'in the reign of Henry 6 [1422-71], bills began to be introduced in the form of complete statutes, which were passed in a manner approaching that of modern times, and received the distinct assent of the king, in the form in which they had been agreed to by both houses of Parliament. It is true that Henry 6, and Edward 4 [1461-83], occasionally added new provisions to statutes, without consulting Parliament; but the constititional form of legislating by bill and statute, agreed to in Parliament, undoubtedly had its origin and its sanction in the reign of Henry VI.' Chitty, n 5, p 3 'The royal legislative right is not of the deliberative kind; the Crown has no power to propound laws; and it would have a dangerous tendency and influence, if the king were allowed to recommend from the throne what laws ought to be passed; as was done by some of our arbitrary sovereigns, and by the Roman Emperors, whose orationes were the exact patterns to which the senatus consulta were to conform.'
} 


\section{CROWN PREROGATIVES - ASSEMBLY OF PARLIAMENT}

There are 6 scenarios in respect of the assembly of Parliament, viz:

- Summoning;

- Opening;

- Meeting;

- Proroguing;

- Adjourning;

- Dissolving. ${ }^{66}$

In respect of these, the present position is discussed. Then, the manner of a suggested modernisation of the same. However, it should be indicated - from the outset - that all of these matters are opaque in their legal description and extent. Also, they are out of kilter with modern day realities. Thus, they do not reflect the factual reality that Parliament now meets very frequently. Also, that the role of the sovereign is now a formal, and not an executive, one. Why the nature, and scope, of these scenarios are opaque may be readily explained by having regard to history and the power struggles between the Crown and Parliament. Thus, for example,

- Infrequent Meetings of Parliament. After Norman times, the Crown was, often, impecunious (many sovereigns were profligate). Thus, the Crown needed financial supply from Parliament. However, in return for the same, Parliament (often) sought a reduction (or limitation) in the prerogatives of the Crown. Parliament, also, sought to accrue more power to itself at the expense of the Crown. The result was that - up to the time of the Civil War (16429) - the Crown sought to call Parliaments as infrequently as possible, regardless of the strict legislative position. Hence, legislation on the meeting of Parliament, and its opacity, reflects this - even to this day;

- Control over Parliament. The Crown sought to control Parliament, in particular, by specifying that only the sovereign (or his/her representatives) could summon, open, prorogue or dissolve Parliament. And, that Parliament could only adjourn itself with royal consent/approval. After the Glorious Revolution 1688, it was inevitable that the role of sovereign in these matters would become increasingly formal as Parliament became supreme. Yet, these Parliamentary procedures relating to assembly - even today - still fail to reflect the reality of the supremacy of Parliament and make it, instead, subject to the Crown;

- Complex Terminology. In order to hide the nakedness of the power struggle between Parliament and the Crown, often, a complex 'in house' terminology was developed. Thus, arcane language was used - such as the retaining of Anglo-Norman (law French) expressions which, today, are long past their sell-by date (see 13). Also, the custom and practice of Parliament became a 'science' only capable of interpretation by the cognoscenti. That is, by Crown servants (including lawyers) and their Parliamentary equivalents (who were, also, often appointed by the Crown and, thus, had conflicting loyalties). Further, little attempt was made to modernise the law on Parliament since this suited the retention of sinecures, 'jobs for life' and 'jobs for the boys'.

Sadly, much of these 'power saving' devices still exist today and they militate against a clear understanding of Parliament. Also, the need for transparency in the operation of Parliament which is the primary vehicle for sustaining democracy in the UK. Further, today - sometimes - every argument is used to retain many obsolete (or unfair) practices by those with vested interests when there are no good legal (or practical) grounds for retaining the same. Bearing the above in mind, consideration will now be given to the legal grounds relating to the assembly of Parliament - and their modernisation. In respect of the latter, regard may be had to the recent decision of the Supreme Court in R (Miller) v Prime Minister (2019) ('Miller'). ${ }^{67}$ This is analysed, to a limited extent, in $\mathbf{1 1 .}$

\section{CROWN PREROGATIVES - SUMMONING PARLIAMENT}

\section{(a) Present Position}

Chitty (writing in 1820) stated:

The king alone is entitled by the constitution to summon a Parliament, nor can this power be vested in any other department of the State with equal propriety; because, to borrow the words of Sir W[illia]m Blackstone, the king is a single person, whose will may be uniform and steady; the first person in the nation, being superior to both houses

\footnotetext{
${ }^{66}$ Many legal texts have failed to separate out these distinct scenarios, often, creating confusion. Thus, the opening (convening, meeting) of Parliament is not the same as to when Parliament must meet.

${ }^{67}$ [2020] AC 373. See also two Scots decisions Cherry QC, Petitioner (no 2), Court of Session (Outer House) 4 September 2019, 2019 SLT 1071 ('Cherry $\boldsymbol{O H}^{\prime}$ ') and Cherry, QC v Advocate General (11 Sept 2019) Court of Session, Inner House ('Cherry IH').
} 
in dignity, and the only branch of legislature that has a separate existence, and is capable of performing an act at a time when no Parliament is in being. ${ }^{68}$ (italics supplied)

That said, Chitty cited two instances ${ }^{69}$ in which Parliament summoned itself, viz. the Convention Parliament Act $1660^{70}$ and the Crown and Parliament Convention Act $1688 .{ }^{71}$ Both cases ${ }^{72}$ derived from there being an interregnum.

- In the first case, Charles I (1625-49) had been executed in 1649. Thus, there was no sovereign to summon Parliament in 1660 for the purpose of inviting Charles II (1660-85) to become sovereign;

- In the second case, James II (1685-8) had fled the realm. Thus, there was no sovereign to summon Parliament in 1688 to elect his successors, William III and Mary (1688-1702) (in any case, James II (1685-8) would have refused to undertake this, still desiring the throne).

For his part, May (in 1844) stated:

It is by the act of the Crown alone that Parliament can be assembled. The only instances in which the lords and commons have met by their own authority, were, previously to the restoration of king Charles 2 [in 1660] and at the revolution in 1688: but as those cases arose in times of extraordinary emergency, when the constitution was suspended, they serve only to confirm the general law and the prerogative of the Crown. ${ }^{73}$

\section{(b) Method of Summoning Parliament}

Parliament was summoned by the following methods:

$$
\begin{aligned}
& \text { - Writ of Summons } ;{ }^{74} \text { or by } \\
& \text { - Proclamation. }
\end{aligned}
$$

In the past, there was a delay between the issue of a summons and Parliament assembling of 40-50 days (later 14 days). Such was to take account of Parliamentarians living in distant parts having to travel to London. ${ }^{75}$ Today, the Meeting of Parliament Act 1870, s 1 (summoning of Parliament) states:

\footnotetext{
${ }^{68}$ Chitty, n 3, p 68. Ibid, p 3 '[HM] alone can call Parliament together, and dissolve its authority...'. Ibid, p 6 'With regard to the houses of Parliament, the right to assemble, prorogue, and dissolve them, belongs exclusively to the king as supreme executive magistrate.' May (in 1844), n 3, p 31 'It is by the act of the Crown alone that Parliament can be assembled.'

${ }^{69}$ Ibid. 'There are indeed two memorable instances on record, in which Parliament have assembled without the authority of the king; and have, when so assembled, effected most momentous revolutions in the government. I allude to the Parliament which restored Charles 2 [1685-8]; and to the Parliament of 1688 which disposed of the British Crown to William III [1688-1702]. But in both these instances the necessity of the case rendered it unnecessary for the Parliament to meet as they did, there being no king to call them together, and necessity supercedes all law.'

${ }^{70}$ Confirmed by 13 Cha 2 St 1 cc $7 \& 14$ (1661). See also Bowyer, $n$ 35, pp 79-81.

${ }^{71}$ The Convention Parliament Act 1688, s 1 (extant) states: 'The Lords spiritual, temporal and Commons convened at Westminster [22 Jan 1688] sitting on [13 Feb] following are the two Houses of Parliament and so shall be and are hereby declared, enacted and adjudged to be to all intents, constructions and purposes whatsoever notwithstanding any want of writ or writs of summons or any other defect of form or default whatsoever as if they had been summoned according to the usual form.' This Act should be repealed as obsolete, see n 1, p 57.

${ }^{72}$ There are actually 3 cases when Parliament summoned itself, see the writs issued when Henry IV (1399-1413) took the throne after the deposition of Richard II (1377-99), mentioned by Bowyer, n 35, p 79.

${ }^{73}$ May (in 1844), n 3, p 31. He continued 'The first act of [Charles II's] reign [i.e. the Convention Parliament Act 1660] declared the lords and commons to be the two houses of Parliament, notwithstanding the irregular manner in which they had been assembled, and all their acts were confirmed by the succeeding Parliament summoned by the king; which however qualified the confirmation of them, by declaring that 'the manner of the assembling, enforced by the difficulties and exigencies which they lay upon the nation, is not to be drawn into example'. In the same manner the first Act of the reign of William and Mary declared the convention of lords and commons to be the two houses of Parliament [i.e. The Crown and Convention Parliament Act 1688], as if they had been summoned according to the usual form; and the suceeding Parliament recognised the legality of their acts.'

${ }^{74}$ Described by Chitty (in 1820), n 5, pp 69-70. Coke, n 19, vol 4, p 4 'The king de advisamento concilii... resolving to have a Parliament, doth out of the court of chancery send out writs of summons at least forty days before the Parliament begins...'.

${ }^{75}$ As to the position in 1844, May, n 3, pp 33-4 'The Parliament is summoned by the queen's writ or letter issued out of chancery, by advice of the privy council. By the $7 \& 8$ Will 3, c 25 [rep], it is required that there shall be 40 days between the teste and the return of the summons; but since the union with Scotland, it has been the invariable custom to extend this period to 50 days. The writ of summons has always named the day and place of meeting, without which the requisition to meet would be imperfect and nugatory.' The 40 day period may have arisen from Magna Carta. Ibid, p 16. See also Hatsell (in 1785), n 23, pp 213-21. Also, Pronay, n 23, p 80 citing the Modus Tenendi Parliamentum (c. 1320).
} 
Parliament may be summoned by a royal proclamation in manner provided by the recited Acts, ${ }^{76}$ to meet on any day not less than [6] days from the day of the date of such proclamation, and the recited Acts, so far as they relate to such summoning of Parliament, shall be construed as if [6] days were therein substituted for [14] days. ${ }^{77}$

\section{(c) Suggested Modern Position}

It is suggested that a Parliament Act provide that:

- $\quad$ Parliament shall be summoned by means of a proclamation (see 1870 Act above);

- The proclamation should appoint the: (a) day; and (b) place, of meeting;

- The Crown prerogative to summon by writ should be abolished;

- The minimum time between summons and assembly should be 6 days (see 1870 Act above).

Finally, to deal with an interregnum, Parliament should have the capacity to summon itself, by means of a proclamation issued by the Speaker of the HC or the Lord Speaker (or former speakers). ${ }^{78}$

In conclusion, a Parliament Act should provide for the summoning of Parliament by means of proclamation (with a minimum period for assembling to be 6 days thereafter).

\section{CROWN PREROGATIVES - OPENING PARLIAMENT}

\section{(a) Method of Opening}

When Parliament assembles, it is formally opened (convened). That is, it legally commences its business. ${ }^{79}$ This is does on the command of the sovereign in person or at the request (desire) of her proxies - the Lords Commissioners (who act by way of 'representation' or 'commission', as older terminology expressed it). Chitty (in 1820) stated:

The members of each house being thus duly assembled, the Parliament, of which the king has been termed the caput, principium, et finis, [the head, beginning and end] cannot, in point of law, commence but in the presence of [HM], either in person or by representation; which representation may be either by a guardian of England, by letters patent under the great seal, when the king is in remotis out of the realm, or by commission under the great seal of England, to certain lords of Parliament, representing the person of the king, he being within the realm, in respect of some infirmity, or his being engaged in other urgent affairs. ${ }^{80}$

For his part, May (in 1844) stated:

As the queen appoints the time and place of meeting, so also at the commencement of every session, she declares to both houses the cause of summons, by a speech delivered to them in the [HL] by herself in person or by commissioners appointed by her. Until she has done this, neither house can proceed with any business: but the causes of summons as declared from the throne, do not bind Parliament to consider them alone, nor to proceed at once to the consideration of any of them. ${ }^{81}$

The position as to the opening of Parliament in person has changed little, see May (in 2019). ${ }^{82}$

\section{(b) No Obligation to Attend in Person}

The sovereign has never had an obligation to attend the opening (convening) of Parliament in person. This may be done, as noted, by proxy, the sovereign using her servants - the Lord Commissioners - to undertake the same. Thus, May (in 1844) stated:

On the day appointed by royal proclamation for the first meeting of a new Parliament for despatch of business, the members of both houses assemble in their respective chambers. In the [HL], the lord chancellor acquaints the house,

'that [HM] not thinking it fit to be personally present here this day, had been pleased to cause a commission to be issued under the great seal, in order to effect the opening and holding of this Parliament.'

\footnotetext{
${ }^{76}$ This is a reference to the Meeting of Parliament Act 1797 and the Meeting of Parliament Act 1799.

${ }^{77}$ May (2019), n 4, p 164 'A new Parliament is summoned to meet by a proclamation issued by the queen on the advice of the privy council. This proclamation appoints a day and place for the meeting of the new Parliament.'

${ }^{78}$ See also May (2019), n 4, p 61 'By the Ministerial and other Salaries Act 1975, s 1(3) it is provided that in the case of a dissolution the then speaker shall be deemed to be the speaker, for the purposes of that Act, until a speaker has been chosen by the new Parliament. Similar provision is made in the House of Commons (Administration) Act 1978, schs 1 and 2.'

${ }^{79}$ The older expression used was 'convened'.

${ }^{80}$ Chitty, n 5, pp 70-1. May (in 1844), n 3, pp 34-5 'Parliament....can only commence its deliberations at the time appointed by the queen...'. See also Coke, n 19, vol 4, p 2 'Of this court of Parliament the king is caput, principium et finis...'. Ibid, p 6.

${ }^{81}$ May (in 1844), n 3, p 34.

${ }^{82}$ May (in 2019), n 4, pp 179-80.
} 
The lords commissioners, being in their robes, and seated on a form between the throne and the woolsack, then command the gentlemen usher of the Black Rod to let the commons know 'the lords commissioners desire their immediate attendance in the house to hear the commissions read'.... the lord chancellor then addresses the members of both houses, and acquaints them that [HM] has been pleased:

'to cause letters patent to be issued, under her great seal, constituting us, and other lords therein mentioned, her commissioners, to do all things in [HM's] name, on her part necessary to be performed in this Parliament. ${ }^{83}$

Alternatively, the sovereign may provide for the opening of Parliament by issuing a proclamation. Finally, it may be noted that the Queen does not have any (legal) obligation to ride up in a coach (or vehicle) to open Parliament. This is pure ceremony; she could come on foot.

\section{(c) No Obligation to give Address in Person}

At the opening of Parliament, there is no obligation of the sovereign to address Parliament in person. This may be done by a Lords Commissioner (or, indeed, by anyone else she instructs; in the past it tended to be the Lord Chancellor). It is suggested that, today, a senior member of the royal family - such as the duke of Cornwall - would seem more appropriate than a Lord Commissioner. ${ }^{84}$ Further, since the address is a political statement by the government, it would seem (perhaps) more appropriate that, today, it be given by a member of the government - the PM - which address is then debated in Parliament with the opposition replying. In conclusion, the sovereign - whose role is now only a formal one - should be kept away from making any political statements.

\section{(d) Suggested Modern Position}

The requirement of the Crown opening Parliament in person (or through her representatives, the lords commissioners) reflects the older position (pre-1688) of the Crown controlling Parliament. Not the modern position which reflects the reality that the sovereign only exercises a formal (ceremonial) role. Further, Lords Commissioners, today, can also be officers of Parliament (such as the Lord Speaker of the HL). This creates a conflict of interest (as well as communications between the sovereign and Parliament which are not transparent). Thus, provision should be made for Parliament to be opened by the sovereign in person or - failing this - by means of a proclamation. Therefore, the office of Lords Commissioner should be dispensed with. Thus, it is suggested that a Parliament Act provide that:

- Parliament shall be opened by: (a) the sovereign in person; or (b) proclamation;

- In the case of an interregnum, ${ }^{85}$ Parliament shall be opened by a speaker (or former speaker) ${ }^{86}$

- $\quad$ Lord Commissioners should be abolished;

- The address should be delivered by the sovereign in person or by another senior member of the royal family. ${ }^{87}$ Alternatively, it should be delivered by the PM since it is a political statement.

In conclusion, a Parliament Act should make provision on the opening (convening) of Parliament.

\section{CROWN PREROGATIVES - MEETINGS OF PARLIAMENT}

\section{(a) When Parliaments must be Held}

As to how often Parliament should meet, the present legislation is antiquated and out of date. It is as follows:

\footnotetext{
${ }^{83}$ May (in 1844), n 3, pp 133-4. Ibid, p 143, 'When [HM] is not personally present, the causes of summons are declared by the lords commissioners. The gentleman usher of the Black Rod is sent, in the same manner, to the [HC], and acquaints the speaker that the lords commissioners desire the immediate attendance of this honourable house in the House of Peers, to hear the commission read: and when Mr Speaker and the house have reached the bar of the House of Peers, the lord chancellor reads the royal speech of both houses.' For the position in respect of prorogation, see Ibid (in 1844), pp 164-6. See also Hatsell (in 1785), n 23, vol 2, p 223. Campion (in 1929), n 31, p 82 'When the king opens Parliament in person it is customary for him to read the speech himself, but there are many precedents, especially during the reigns of George I [1714-27] and Queen Victoria [1837-1903], for the lord chancellor reading the speech in the royal presence. If Parliament is opened by commission, the speech is read by the lord chancellor, but (since 1867) framed as the speech of the sovereign, not that of the Lords Commissioners.'

${ }^{84}$ The present position is stated in May (2019), n 4, p 180 'When the queen is not personally present, the causes of summons are declared by the Lords Commissioners. Black Rod is sent, in the same manner, to the $[\mathrm{HC}]$, and acquaints the speaker that 'the Lords Commissioners desire the immediate attendance of the honourable house in the [HL], to hear the commission read'; and when the speaker and the [HC] have reached the bar of the [HL], the presiding commissioner reads the royal speech to both houses.' In olden times, it seems that the address was given by the Lord Chancellor or the Lord Chief Justice, see Pronay, n 23, p 84 (citing the Modus Tenendi Parliamentum, c. 1320).

${ }^{85}$ It should be noted that the death (demise) of the sovereign does not create an interregum since the sovereign in the body politic never dies, see McBain, n 1, p 16.

${ }^{86}$ In this respect, for the continuance of the role of speaker for other purposes, see May (2019), n 4, p 61, para 4.29.

${ }^{87}$ As Hatsell (in 1785), n 23, vol 2, p 223 pointed out 'the cause of summons [i.e. the royal address] was delivered 'either by the king himself, or by some person by his command, or by persons authorised by his commission [i.e. the Lords Commissioners].'
} 
- Bill of Rights 1688. S1(13) (frequent Parliaments) states: 'And that for redress of all grievances and for the amending strengthening and preserving of the laws, Parliaments ought to be held frequently.' (spelling modernised, comma added). This wording, which is very vague, was superceded by the 1694 Act (below); ${ }^{88}$

- Meeting of Parliament Act 1694 (the Triennial Act). This provides that Parliament must meet every 3 years. ${ }^{89}$ Thus:

s 1(Parliament to held once in three years at the least) states: 'from henceforth a Parliament shall be held once in [3] years at the least.' 90

s 2 (writs to be issued once in three years) states: 'within [3] years at the farthest, from and after the dissolution of this present Parliament, and so from time to time for ever hereafter, within [3] years at the farthest from and after the determination of every other Parliament, legal writs under the great seal shall be issued by directions of your majesties your heirs and successors, for calling, assembling, and holding another new 'Parliament'.

A further section in the 1694 Act specified the term of Parliament as 3 years ${ }^{91}$ (later, it became 7 years under the Septennial Act 1715). The background to the above legislation has been much mis-understood. However, it needs to be understood when considering issues relating to the term of Parliament (i.e. how long can Parliament sit before a general election must be called) as well as in respect of any prorogation, adjournment or dissolution of Parliament.

\section{(b) Historical Position 1330-1694}

The position is (it is asserted) accurately set out in Pike, A Constitutional History of the House of Lords (1894). He stated:

In the year 1330 it was enacted that Parliament should be held once in every year, or oftener, should there be need. ${ }^{92}$ This rule, however, was not by any means strictly followed, and in the year 1362 there was passed another Act to the same effect. ${ }^{93}$ Like its predecessor this also fell into disuse. ${ }^{94}$

In respect of this:

- In the $14^{\text {th }}$ century, prorogations were few since there were Parliaments with new MP's every year (generally). ${ }^{95}$ Further, prorogations (intermissions of sessions) and adjournments (intermissions from day to day) were treated the same - the word 'prorogation' meaning delaying (putting off) the assembling, since the sovereign was, often, prevented from attending Parliament by absence abroad, illness etc. ${ }^{96}$

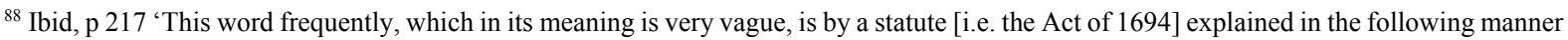
[he cites s 2].' See also W Cobbett, The Parliamentary Register (1809), vol 5, p 860, note 'The necessity of 'frequent Parliaments' had been asserted in the last article of the Declaration of Rights [i.e. the Bill of Rights 1688]; but then it had been asserted in such indefinite terms, that the king [William III 1688-1702] did not think himself obliged to observe it...'. See also Maitland, n 43, p 373 'vague words.'

${ }^{89}$ The preamble states 'An Act for the frequent meeting and calling of Parliaments.'

${ }^{90}$ See also May (in 1844), n 3, p 32-3.

${ }^{91}$ It stated 'no Parliament whatsoever, that shall at any time hereafter be called, assembled, or held, shall have any continuance longer than for [3] years at the farthest [latest], to be accounted from the day, on which by the writs of summons the said Parliament shall be appointed to meet.'

${ }^{92} 4 \mathrm{Edw}$ c 14 (Parliament shall be holden once a year). Item, it is accorded, that a Parliament shall be holden every year once, and more often if need be.' GO Sayles, The King's Parliament of England (1975), p 133 also referred to legislation in 1258 and 1311 (for three Parliaments each year in the first case and one in the second). For this, see W Stubbs, The Constitutional History of England (3rd ed, 1887), vol 2, p 644.

${ }^{93} 36$ Edw III c 10 (Parliament shall be holden once a year) 'Item, for maintenance of the said articles and statutes and redress of divers mischiefs and grievances which daily happen, [a] Parliament shall be holden every year, as another time was ordained by statute.'

${ }^{94}$ That said, it seems that annual Parliaments were held in the 14th century, with the Parliament newly summoned with fresh members. Stubbs, n 92, vol 2, pp 645-6 'annual parliaments were the rule; it was only in unquiet times that the commons found it necessary or advisable to insist on the observance of the rule...'. Also, 'The power of prorogation either before or after the day of meeting rested with the King, and, although in a vast majority of instances the parliaments were newly summoned and the representative members chosen afresh for each session, the few exceptional cases of prorogation are sufficient to prove that the royal right was exercised without hesitation and without producing any irritation.' Stubbs refers to prorogations in 1311,1328, 1333, 1381, 1388 and 1397-8.

${ }^{95}$ Gurdon, $\mathrm{n} 42$, vol 2, p 282 'at this time [c. 1362] prorogations of Parliament were very rare, and if there were some prorogations, yet new summons were to go out for a new Parliament once a year at least. The custom of proroguing and adjourning Parliaments was first brought into practice by Richard II [1377-99] to continue his pack [packed] Parliament...'.

${ }^{96}$ Stubbs, n 92, vol 3, p 498 'The right of suspending the session by adjournment or prorogation, of countermanding a meeting once called, and of dissolving the parliament itself, was throughout the middle ages vested in the king alone. The distinction between adjournment and prorogation, in so far as the one belongs to the houses and the other to the Crown, is a modern distinction. The necessary adjournment from day to day, as well as the countermanding of a Parliament called, and the longer intermission of the session, was known as prorogation: the houses were ordered by the king to meet from day to day until business was finished, and the rule of adjourning at midday originated probably as much in the necessity of dining as in the wish to claim a privilege...The long prorogations, when they become usual, are like the early annual or terminal sessions, defined by the season of harvest and the church festivals.'
} 
- In the later $14^{\text {th }}$ century - and in the $15^{\text {th }}$ century - there were long prorogations as Stubbs noted (he recorded the position up to 1458). ${ }^{97}$ For a statement as to the frequency and duration of Parliaments generally in the medieval period, see Maitland, The Constitutional History of England (1950). ${ }^{98}$

Pike continued:

In the reigns of Henry VIII [1509-47], ${ }^{99}$ Elizabeth [I,1558-1603] and James I [1603-25], ${ }^{100}$ there were intervals of many years during which no Parliament assembled.

More detailed data is provided by Sayles (in 1975):

It has been calculated that between 1400 and 1460 forty to fifty great councils met and twenty two Parliaments...In time the intervals between Parliament and Parliament could run into two or more than three years, as in 1456-58 and 1478-83. At the close of the middle ages Henry VII [1485-1509] summoned only seven parliaments in the whole of his reign from 1485 to 1509: in the last twelve years he summoned only one... Similar neglect or indifference to Parliament was shown by his son, Henry VIII [1509-47]. Let us state the inescapable facts starkly: no session of Parliament was held in 1488, 1493, 1494, 1496, 1498-1503, 1505-9, 1511, 1513, 1516-22, 1524-29 - that is, in twenty-eight out of forty-five years - and there was little protestation about the flouting of constitutional rights. ${ }^{101}$

Pike continued:

In the troubled reign of Charles I [1660-85] there was an interval of twelve years - from 1628 to $1640 .{ }^{102}$ The first Parliament of 1640 sat but a few days. The second passed an Act 'For the preventing of Inconveniences happening by the long intermissions of Parliament. ${ }^{103} \mathrm{~A}$ reference was made, in the preamble, to the Act of [1362] by the words 'Parliament ought to be holden at least once every year for the redress of grievances.' The royal [i.e. the Crown] prerogative was in theory recognised by the words 'but the appointment of the time and place for the holding thereof hath always belonged, as it ought to [HM] and his royal progenitors;' for practical purposes, however, it was reduced to a nullity by the substantive words of the enactment. Whenever the existing or any future Parliament was continued by adjournment or prorogation to the tenth day of September in the third year following the last day of its sitting, it was to be ipso facto absolutely dissolved. The Lord Chancellor, Keeper, or Commissioners for the keeping of the Great Seal were then required to issue, within six days, writs for the summoning of a new Parliament, "without any further warrant or direction from [HM]. ${ }^{104}$

The underlined wording above is important in the context of prorogation and adjournment. The 1640 Act was designed to prohibit the Crown from preventing Parliament from sitting for more than 3 years (but not for less) by proroguing or adjourning the same. ${ }^{105}$ Pike continues:

\footnotetext{
${ }^{97}$ Ibid, p 282 'During the twenty-five years of the York dynasty the country was only seven times called upon to elect a new Parliament; the sessions of those Parliaments which really met extended over a very few months; their meetings being frequently held only for the purpose of prorogation. No Parliament sat between January 1465 and June 1467, or between May 1468 and October 1472; and between January 1475 and January 1483 the assembly was only called together for forty two days in 1478 to pass the attainder of the duke of Clarence... The practice of the later years of Henry VI [1422-71], during which elections had been as much as possible avoided, furnished him with precedents with long prorogations; Edward [IV, 1461-83] suspended parliamentary action for years together; and England, which had been used to speak its mind once a year at least, was thus reduced to silence.' See also p 394 (1364-1458).

${ }^{98}$ Maitland, n 43, pp 177-8.

${ }^{99}$ G Jacob, Lex Constitutionis (1719), p 127 'But Cardinal Wolsey [1473-1530]...expressed a contempt and hatred of Parliaments, and the common law...'twas by his means that a Parliament was held but once in fourteen years during that reign, which was upon a very remarkable occasion, viz. to attaint the good Duke of Buckingham [Edward Stafford 1478-1521].'

${ }^{100}$ DL Keir, The Constitutional History of Modern Britain since 1485 (9th ed 1969), pp 163-3, 'James I assembled four Parliaments, in 1604, 1614, 1621, and 1624. The first continued until the end of 1610, but did not meet between July 1607 and February 1610. No Parliament sat thereafter until April 1614, nor from June 1614 to January 1621, nor between December 1621 and February 1624, and the Parliament then summoned stood prorogued for the last ten months of the king's reign.'

${ }^{101}$ Sayles, $n$ 92, p 134. For prorogations during the reign of Henry VIII, see Tudor Royal Proclamations 1485-1553 (1964). See also Maitland, $\mathrm{n} 43$, pp 248-51 (frequency and duration of Parliaments in the Tudor period).

${ }^{102}$ Keir, n 100, p 163 'Charles I summoned five Parliaments, in 1625, 1626, 1628, and in 1640, when there were two, but the Parliamentary history of his reign is marked by long prorogations as well as by the unprecedentedly long interval between Parliaments which occured from 1929 to 1640. In all, Parliamentary sessions covered less than four-and-a-half of the thirty-seven years elapsing between 1603 and 1640.'

${ }^{103} 16$ Car $1 \mathrm{c} 1$.

${ }^{104}$ Pike, n 37, p 331. He continues, by way of aside "Various provisions were made to ensure the assembling of Parliament should the keepers of the great seal refuse or neglect to issue the writs of summons. Among them was one that peers were to assemble, and, on their own authority, send out writs to summon the Commons.' See also GB Adams \& HM Stephens, Select Documents of English Constitutional History (1933), pp 350-59.

${ }^{105}$ Why adjournment was referred to was that, at that time, the consent of Parliament was required for an adjournment. Further, the Crown had great influence (almost total influence) in the Tudor period over the HL; and very great influence over the HC. Thus, it could persuade
} 
It is sometimes said that triennial Parliaments were established by this Act, but the effect of it was only to ensure that there should not be an interval of more than three years between the sittings of Parliament, and that a Parliament prorogued or adjourned for three years should come to an end and be succeeded by another. ${ }^{106}$ No provision was made for the dissolution of a Parliament which continued its sittings without any interval of the length mentioned in the Act. The Parliament, indeed, in which the Act was made, remained in existence so far as the [HC] was concerned, more than twelve years, and until its sittings were interrupted, not by the automatic action of a statute, but through the master will of Cromwell with his soldiers at this back. ${ }^{107}$

Thus, it seem quite clear that the 1640 Act sought to limit any: (a) adjournment; or (b) prorogation, of Parliament to 3 years at most. It was not designed to deal with an unlimited extension of Parliament presently sitting. This was a lacuna. Another lacuna was that it failed to deal with the dissolution of Parliament, and the sovereign then failing to call another for many years. Pike continued:

Four years after the restoration [i.e. in 1664] this Act [i.e. of 1640] was formally repealed, and declared to have been 'in derogation of [HM's] just rights and prerogative inherent in to the imperial Crown of this realm'. It was also stated in the repealing Act [of 1664] that 'by the ancient laws and statutes of this realm, made in the reign of king Edward the Third, [i.e. the Acts of 1330 and 1362] Parliaments are to be held very often.' As those statutes provided for the holding of a Parliament once every year at least, they can hardly be said to have afforded a very secure ground for the substantive enactment which followed, that Parliaments were to be held once in three years at least. The king was thenceforth to issue out his writs for calling a Parliament within three years of the termination of any previous Parliament. ${ }^{108}$

This Act of 1664 was an even more retrograde step. It allowed Charles II (1660-85) and his successors to adjourn (since they gave consent to the same) or prorogue Parliament indefinitely. Also, to continue a Parliament indefinitely, providing it met, once, every three years. Pike then noted that:

This Act [of 1664], like that of Charles I [i.e. the 1640 Act], did not in any way affect the length of time during which any one Parliament might sit, or require the election of new members of the $[\mathrm{HC}]$ at the end of any definite period. The very Parliament in which it was passed continued in existence nearly seventeen years. All that was needed was that some kind of Parliament should be called together at intervals of not less than three years, just as some kind of Parliament was to be called together at intervals of not less than one year at the beginning of the reign of Edward III [a reference to the Act of 1330]. ${ }^{109}$

In short, there was a lacuna in this Act of 1664 - in that all the sovereign needed to do in order to circumvent the Act was either:

- $\quad$ to prolong the sitting of Parliament (providing there was one sitting every 3 years); or

- $\quad$ to adjourn or prorogue Parliament (for up to 3 years); or

- $\quad$ after a dissolution, to delay the calling of a new Parliament (for up to 3 years).

All these circumventions occurred in the reigns of Charles II (1660-85) and William and Mary (1688-1702). ${ }^{110}$

\section{(c) Historical Position 1694 - Date}

Pike then stated:

In the year 1694 another Act [i.e. the Triennial Act] was passed requiring, like that of the reign of Charles II [i.e. the Act of 1664], that a Parliament should be held once in three years at least. It contained a further provision that no

sufficient MP's and members of the HL to adjourn and, if they refused, simply to prorogue them. Keir, n 100 , p 136 'The [HL] under the Tudors was on the whole a complaisant body, 'sprung from the willow rather than the oak.'

${ }^{106}$ It is not clear whether this was adequately explained in Miller (2019), n 67

${ }^{107}$ Pike, n 37, pp 331-2. For a summary, see also Maitland, n 43, pp 292-3 (frequency and duration of Parliaments)

${ }^{108}$ Ibid. The 1664 Act is 16 Car II c I.

${ }^{109}$ Ibid, n 37, p 332. See also TE May, The Constitutional History of England (1882), vol 1, p 440.

${ }^{110}$ Ibid, pp 332-3 'Charles II [1660-85], at the end of his reign, allowed four years to elapse without summoning any Parliament. There was no power, under the Act, to compel him to issue any summons, and no machinery for summoning a Parliament without his consent. In the reign of William and Mary, also, the first Parliament (after the Convention) [in 1668] was continued six years and a half... The time, however, was at hand when Parliaments were to be held every year though not under any legal compulsion.' For a summary, see also Maitland, $\mathrm{n} 43$, pp 294-7 (frequency and duration of Parliaments 1654-1694). 
Parliament should continue in existence more than three years... ${ }^{11}$ there never since been a year in which a Parliament has not met...112

In the year 1715 the continuance of Parliaments was extended to seven years, ${ }^{113}$ but the provisions relating to the holding of a Parliament once in three years, and to the summoning of a Parliament within three years remained in force. The sole effect of the new Act was to give to the representatives of the Commons a longer period of representation, though, subject of course, to the sovereign's power of dissolving. Portions of the Act of the reign of William and Mary were formally repealed in the year 1867, but only portions rendered inoperative by the Act of George I [i.e. the Act of 1715], and portions relating to the Parliament in which the Act itself was passed.

It would seem, therefore, that the Parliamentary functions of the [HL] as well as those of the [HC], might still be legally suspended for a period of three years, because the Acts of Edward III [i.e. those of 1330 and 1364] relating to annual Parliaments, already superceded by those of Charles II [1660-85] and William and Mary [1688-1702], were formally repealed in 1863 . The security for annual sessions of Parliament lies in the power of the Commons to grant or withhold supplies, and in the necessity for a vote to appropriate them when granted. ${ }^{114}$ (underlining supplied)

Thus, Pike was indicating (writing in 1894) that the 1694 Act was still extant. And that, pursuant to it, Parliament 'might still be legally suspended for a period of three years' ${ }^{115}$ Such is correct - Parliament can be prorogued or adjourned for up to 3 years pursuant to the Act. However, in practice, annual Parliaments occur because of the need for supplies.

\section{(d) $\underline{\text { Historical Position } 1694 \text { - Date }}$}

The 1694 Act does not apply to the term of a new Parliament - as Chitty noted in $1820^{116}$ - since a new Parliament had to be called under the Septennial Act 1715 (rep) every 7 years. ${ }^{117}$ This was reduced to a period of 5 years by the Parliament Act 1911(see now the Fixed Term Parliament Act 2011 which replaced it, see 12). However, the 1694 Act still stands in respect of the following:

- $\quad$ Prorogation - Parliament cannot be (legally) prorogued for more than 3 years (1694 Act, s 1);

- $\quad$ Adjournment - Parliament cannot be (legally) adjourned for more than 3 years (ibid);

- $\quad$ Dissolved - Once dissolved, Parliament cannot remain so for more than 3 years (1694 Act, s 2). ${ }^{118}$

However, in practice, the Bills of Rights 1688 provision to hold Parliaments 'frequently' has no legal content, being too vague. And, in reality, the 1694 Act is obsolete since, in practice, Parliament must meet every year to fund public services which May (2019) notes, ${ }^{119}$ as does a note in Halsbury, Statutes of England and Wales which states:

The necessity for frequent Parliaments in modern times depends more on the practical requirements of government rather than the statutory position. It would be impossible to have a period of [3] years elapse without any Parliament

\footnotetext{
${ }^{111}$ This was the Triennial Act of 1694 (6 Will \& Mary c 2), still extant.

${ }^{112}$ Cobbett, $\mathrm{n} 88$, vol 5, p 860 noted that the bill passed very quickly, probably because the sovereign (William III) needed supply (money), 'The bill was easily drawn up, and presented November 22nd, and read with despatch the third time, and past December the 13th; and sent up to the lords [HL], who on the 18th, gave it their concurrence, without any amendments.'

${ }^{113}$ This was the Septennial Act of 1715 (1 Geo 1 st 2 c 38).

${ }^{114}$ Pike, n 37, p 334.

${ }^{115}$ One of the reasons for lawyers mis-understanding the 1694 Act is that legal historians tended to concentrate on what they considered was the primary intent of the Act, e.g. Maitland, n 43, p 296 'This Act was directed not so much against intermissions of Parliament, though it repeated what was already law, namely, that a Parliament shall be holden once every three years at least, but against long Parliaments: no Parliament is to endure for more than three years - it is then to die a natural death.' See also Ibid, pp 373-4.

${ }^{116}$ Chitty, n 5, p 68 'By the [Meeting of Parliament Act 1694] it is declared and enacted that Parliaments shall be holden one in [3] years at least; by which we are not to understand that the king ought to convene within that period a new Parliament, for as the law now stands, Parliaments last for [7] years, unless sooner dissolved by royal authority.' May (in 1844), n 3, p 32 'although the queen may determine the period for calling Parliaments, her prerogative is restrained within certain limits; as she is bound by statutes to issue writs within [3] years after the determination of a Parliament; while the practice of providing money for the public service by annual enactments, renders it compulsory upon her to meet Parliament every year.'

${ }^{117}$ This Act stated: 'Be it enacted ... that this present Parliament, and all Parliaments that shall at any time hereafter be called, assembled, or held, shall and may respectively have continuance for [7] years, and no longer, to be accounted from the day on which by the writ of summons this present Parliament hath been, or any future Parliament shall be, appointed to meet, unless this present or any such Parliament hereafter to be summoned shall be sooner dissolved by [HM], his heirs or successors.' See also May (2019), n 4, p 164. Also, May, n 109, pp 440-1.

${ }^{118}$ Campion, n 31, p 75 'The summoning and dissolution of Parliament are acts performed by the Crown, the statutory condition being the requirement that a new Parliament shall be summoned within three years after a dissolution (6 W \& M c 2)[i.e. the 1694 Act].'

${ }^{119}$ May (2019), n 4, p 164 'the practice of providing money for the public service by annual enactments renders it necessary for Parliament to meet every year.'
} 
existing, as contemplated by this section [i.e. the 1694 Act, s 1], since all financial arrangements for the public service are made on an annual basis and Appropriation Acts authorising expenditure are limited accordingly. ${ }^{120}$

\section{(e) Suggested Modern Position}

The modern reality is that Parliament meets every year. And, it meets often in that year. Indeed, it needs to do so since the demands on it are so great - including the need to finance the operations of government (as well as the operation of Parliament itself). Further, the provision on 'frequently' holding Parliaments in the Bill of Rights 1688 and the 1694 Act are obsolete. Indeed, the latter is somewhat dangerous to retain, since it enables the Crown to:

- $\quad$ Prorogue Parliament for up to 3 years; or

- Not to call a new Parliament after a dissolution for up to 3 years.

Further, it would enable the opposition and Government to (collusively) adjourn Parliament for up to 3 years while they go off to do other things. Thus, there would seem a compelling case for a Parliament Act to reflect modern realities. Thus, it is suggested that it provide that:

- $\quad$ Parliament must meet (i.e. hold a session) every year; ${ }^{121}$

- Within that year, it must meet for a minimum period of [say] 200-250 days a year; ${ }^{122}$

- Such an obligation should not be affected by any prorogation, adjournment or dissolution of Parliament. ${ }^{123}$

In conclusion, Parliament should meet:(a) every year; (b) for a minimum period of 200-250 days; and (c) such should apply regardless of any prorogation, adjournment or dissolution.

\section{CROWN PREROGATIVES - ADJOURNMENT OF PARLIAMENT}

\section{(a) Meaning of Adjournment}

As Jacob noted in his Law Dictionary (1729), the words 'adjournment' and 'prorogation' were, once, treated as synonyms for the concept of 'putting off' (i.e. suspending, delaying) Parliament. ${ }^{124}$ Thus, these Parliamentary concepts were, once, treated as one and the same. However, by the time of Lord Coke (1552-1634), they were distinct, as he noted in his Institutes of the Laws of England (part 4, published in 1641).

The diversity [i.e. the difference] between a prorogation and an adjournment, or continuance of the Parliament, is, that by the prorogation in open court, there is a session, and then such bills as passed in either house, or by both houses, and had no royal assent to them, must at the next assembly begin again, etc. for every several session of Parliament is in law a several [i.e. distinct] Parliament: but if it be but adjourned or continued, then is there no session: and consequently, all things continue still in the same state they were in before the adjournment or continuance...' ${ }^{125}$ (italics supplied)

There was another distinction between adjournment and prorogation. One which has become more accentuated. ${ }^{126}$

- The word 'adjournment' became used to describe the act of Parliament (a consensual agreement) to suspend the meeting of Parliament, while the word 'prorogation' remained the word to describe the act of the Crown (a command to Parliament to suspend itself).

- The fact that prorogation was personal to the sovereign is exemplified in the reign of the 'mad' king George III (1760-1820). During his insanity in 1788, the Lord Chancellor was unable to get the king's consent to attaching the

\footnotetext{
${ }^{120}$ Halsbury, Statutes of England and Wales (4th ed), vol 10(1) (2020 re-issue), editorial note.

${ }^{121}$ Annual meeting is the position once reflected in old legislation. May (in 1844), n 3, p 32 'The annual meeting of Parliament...has, in fact, been the law of England from very early times.' He cited 4 Edw 3 c 14 (1330, rep), 36 Edw 3, c 10 (1362, rep) and 16 Cha 1 c 1 (1640, rep). It is clear that this legislation referred the Parliament meeting at least once a year (i.e. a session being held at least once a year) - not to requiring there to be a general election every year, see Hatsell (in 1785), n 23, vol 2, pp 215-7.

${ }^{122}$ Presently, Parliament meets for c. 150 days. However, this is insufficient to process the huge volume of legislation and there is a backlog.

${ }^{123}$ The reason is to prevent the primary obligation being undermined (e.g. politicians could, then, agree to adjourn Parliament for (say) 290 days to undermine the 200-250 day requirement).

${ }^{124} \mathrm{Jacob}$, n 46 (prorogue)(prorogare) 'Signifies to prolong, or put off to another day. 6 Hen 8 c 8 [actually, c 16, 1514]. Prorogation of the Parliament and adjournment were anciently used as synonyma's [synonyms]; but of late there hath been a distinction, a prorogation making a session, and an adjournment only a continuance.' Ibid (adjournment) '(adjournamentum). The same with the French word adjournement, and signifies a putting off until another day, or to another place.'

${ }^{125}$ Coke, n 19, vol 4, p 27. May (2019), n 4, p 164 'A prorogation terminates a session; an adjournment is an interruption in the course of a single sesssion.'

${ }^{126}$ Historically, adjournment also required the consent of the sovereign. It still does, technically, although - in modern times - it is unlikely that the sovereign would refuse to give his/her consent.
} 
great seal to command the proroguing of Parliament. Thus, Parliament had to be adjourned as noted by May in his Constitutional History of England (1882). ${ }^{127}$

\section{(b) Historical Background - 1820}

In respect of the historical background, Chitty (writing in 1820) noted:

The two houses, respectively, possess the exclusive power of adjourning themselves, nor can the king exercise it; and an adjournment of one house is not, ipso facto, an adjournment of the other. It appears, however, to have been usual, when the king signified his pleasure that both or either of the houses should adjourn themselves to a certain day, to obey the king's pleasure so signified, and to adjourn accordingly. Otherwise, besides the indecorum of a refusal, a prorogation would assuredly follow; which, as it terminates the session, would occasion great inconvenience to public and private business.

An adjournment may be made by the houses not only from day to day, but for a fortnight, or a longer period, as is usually done at Christmas or Easter, or upon other particular occasions; but the king may, by proclamation, call them together at the end of [14] days from the date thereof, notwithstanding any previous adjournment to a longer or more distant day. ${ }^{128}$

The wording in italics reflected the prerogative (power) of the Crown to require Parliament to foreshorten (by proclamation) any adjournment which is more than 14 days. This is contained in the Meeting of Parliament Act 1799 (still extant). ${ }^{129}$ With the preamble 'An Act for empowering [HM] to shorten the time for the meeting of Parliament in cases of Adjournment', it states:

- $\mathrm{S} 1$ ([HM] may issue his royal proclamation for the meeting of Parliament in not less than 14 days from the date, notwithstanding any previous adjournment to a longer day) 'in all cases where both houses of Parliament shall stand adjourned for more than [14] days from the day of the date of the proclamation herein-after mentioned, it shall and may be lawful for [HM], his heirs and successors, to issue his and their royal proclamation, by and with the advice of his and their privy council, thereby declaring that the said Parliament shall meet on a day, being not less than [6] days ${ }^{130}$ from the day of the date of such proclamation, and the houses of Parliament shall thereupon stand adjourned to the day and place declared in such proclamation, notwithstanding any previous adjournment of the houses of Parliament to any longer day, and notwithstanding any former law, usage or custom to the contrary.'

- $\quad \mathrm{S} 2$ (how orders made by Parliament shall be deemed to have been appointed.) 'and all and singular the order or orders which shall have been made by either house of Parliament, and appointed for the day to which such house of Parliament shall have been adjourned or to any day or days subsequent thereto, other than and except any order or orders that shall have been specially appointed for particular days by either house of Parliament and declared to be so fixed notwithstanding any meeting of Parliament under this Act, and also except any order or orders made under the provisions of any Act of Parliament, shall be deemed and taken to have been appointed for the day on which the Parliament shall meet in pursuance of such proclamation.'

(c) Historical Background - 1844

May (writing in 1844) noted:

Adjournment is solely in the power of each house respectively. It has not been uncommon, indeed, for the pleasure of the Crown to be signified in person, by message, commission, or proclamation that both houses should adjourn. But although no instance has occurred in which either house has refused to adjourn, the communication might be disregarded. Business has frequently been transacted after the king's desire has been made known, and the question for adjournment has afterwards been put, in the ordinary manner, and determined after debate, amendment and division. Under these circumstances it is surprising that so many instances of this practice should have occurred in modern times. Both houses adjourn at their own discretion, and daily exercise their right. Any interference on the part of the Crown is therefore impolitic, as it may chance to meet with opposition; and unnecessary, as the ministers need only assign a cause for adjournment, when each house would adjourn of its own accord. The last occasion on

\footnotetext{
${ }^{127}$ May, n 109, vol 1, p 207 'Parliament stood prorogued to the 1st November, and a proclamation had appeared in the 'Gazette', declaring the king's pleasure that it should be further prorogued by commission to the 29th. But before this commission could be signed, [HM] became so ill that the lord chancellor, unable to obtain his signature, did not feel justified in affixing the great seal; and in view of his duty, statesmen of all parties concurred. Following the precedent of 1788, both Houses met on the 1st November; and on being informed of the circumstances under which they were assembled, adjourned until the 15th...' See also Bowyer, n 35, p 97.

${ }^{128}$ Chitty, n 5, p 71.

12939 \& 40 Geo 3 c 14. Ridges (in 1934), n 24, p 50 states 'where both houses stand adjourned for more than fourteen days, it can compel their meeting at an earlier date by proclamation.

${ }^{130}$ The figure of 14 days was changed to 6 days by the Meeting of Parliament Act 1870, s 2 .
} 
which the pleasure of the Crown was signified was on $1^{\text {st }}$ March 1814, and after the lapse of 30 years, it is probable that the practice will never be resorted to again. ${ }^{131}$

A power of interfering with adjournments in certain cases has been conceded to the Crown by statute. The $39 \& 40$ Geo 3, c 14, [Meeting of Parliament Act 1799] enacts that when both houses of Parliament stand adjourned for more than 14 days, the queen may issue a proclamation with the advice of the privy council, declaring that the Parliament shall meet on a day not less than 14 days from the proclamation; and the houses of Parliament then stand adjourned to the day and place declared in the proclamation; and all the orders which may have been made by either house, and appointed for the original day of meeting, or any subsequent day, stand appointed for the day named in the proclamation. ${ }^{132}$

In conclusion, the last time Parliament was commanded (his 'pleasure') by the sovereign to adjourn was in 1814. This Crown prerogative is now obsolete and whether to adjourn (or not) is left to Parliament. However, the sovereign may still - pursuant to the 1799 Act (see (b)) - by proclamation, curtail any adjournment decided on by Parliament to 6 days.

\section{(d) Current Position on Adjournment}

May (2019) states:

The prorogation of Parliament is a prerogative act of the Crown...But each house exercises its right to adjourn itself independently of the Crown and of the other house...In the Commons, the duration of a periodic adjournment, as opposed to the adjournments which occur each day, is determined by resolution. The question on the resolution is put forthwith (Standing Order no 25). In the Lords there is no special procedure for determining the periodic adjournment. ${ }^{133} \mathrm{An}$ adjournment does not have the same effect on parliamentary proceedings as does a prorogation. Upon reassembling, each house proceeds to transact the business previously appointed, and all proceedings are resumed at the stage at which they were left before the adjournment. Select committees are regularly given the power to meet during adjournments. ${ }^{134}$

A power of interfering with adjournments in certain cases has been conceded to the Crown by statute. The Meeting of Parliament Act 1799 [amended by the Meeting of Parliament Act 1870], provides that when both houses of Parliament stand adjourned with more than 14 days still to run, the queen may issue a proclamation, with the advice of her privy council, declaring that the Parliament shall meet on a day not less than [6] days from the proclamation, and the houses then stand adjourned to the day and place declared in the proclamation; and all the orders which have been made by either house and appointed for the original day or meeting, or any subsequent day, stand appointed for the day named in the proclamation. ${ }^{135}$

For its part, the Supreme Court in Miller (2019) stated:

Prorogation must also be distinguished from the house adjourning or going into recess. This is decided, not by the Crown acting on the advice of the [PM], but by each house passing a motion to that effect. The houses might go into recess at different times from one another. In the [HC] the motion is moved by the [PM]. In the [HL], it is moved by the Lord Speaker. During a recess, the house does not sit but Parliamentary business can otherwise continue as usual. Committees may meet, written Parliamentary questions can be asked and must be answered. ${ }^{136}$

\section{(e) Power of Speaker to Curtail an Adjournment}

The Speaker of the HC may, also, curtail (foreshorten) an adjournment. Under Standing Order no 13, the government may make representations to the speaker of the $\mathrm{HC}$ that the house should curtail an adjournment (the Lord Speaker has a similar power for the HL). If the Speaker of the HC is satisfied that the public interest requires such a meeting, he may give notice accordingly; whereupon the $\mathrm{HC}$ meets at the time stated in the notice. ${ }^{137}$

\section{(f) Suggested Modern Position}

It is suggested that the following - in relation to adjournment - be abolished as an inappropriate interference in the operation of Parliament since the role of the sovereign is now only a formal one:

\footnotetext{
${ }^{131}$ It seems clear from Hatsell (in 1785), n 23, pp 225-32 that, from the 1620's at least, the HC was asserting that they did not have to adjourn on the sovereign's command (though they never challenged it). Ibid, p 230.

${ }^{132}$ May (in 1844), n 3, pp 35-6.

${ }^{133}$ May (2019), n 4, p 165.

${ }^{134}$ Ibid, p 166.

${ }^{135}$ Ibid, p 168.

${ }^{136}$ Miller, n 67, p 395.

${ }^{137}$ May (2019), n 4, pp 168-9.
} 
- Crown Prerogative to Consent to an Adjournment. May's writing in 1844 indicates the beginning of the end of the Crown's prerogative to require its consent to an adjournment - last exercised in 1814 (more than 200 years ago). Today, it is suggested this Crown prerogative is inappropriate and should be abolished.

- Crown Prerogative to End an Adjournment. Also abolished should be the Crown's prerogative (contained in the Meeting of Parliament Act 1799) which enables the sovereign to curtail (i.e. to fore-shorten) an adjournment. This should belong to the speaker of the HC, see below.

The following would also seem appropriate:

- $\quad$ Power of Speaker to Recall. The power of the speaker to recall Parliament earlier (see Standing Order no 13 above) should be placed in a Parliament Act;

- $\quad$ HC and HL Adjournments Linked. If the HC is adjourned (or recalled) this should automatically do the same to the HL.

If a Parliament Act were to stipulate that Parliament must meet for a certain number of days, see 7, it would also seem appropriate to provide that Parliament can only agree to adjourn for a number of days less than that stipulated number, in order to prevent the primary obligation being subverted (i.e. Parliament should only be able to adjourn for, say, a maximum of $165-$ 115 days out of 365 days in any year). Such may be achieved be making any section on adjournment subject to the section on the number of days that Parliament must meet. The position as to the demise of the Crown during an adjournment has been previously discussed and does not seem to be problematic. ${ }^{138}$

In conclusion, any Crown prerogative to interfere in the adjournment of Parliament should be abolished.

\section{CROWN PREROGATIVE - PROROGATION}

This Crown prerogative is - among all those relating to Parliament - likely to be the most contentious (as it has proved to be) since it permits the Crown to curtail the sitting of Parliament without the consent of Parliament. However, its retention - as a necessary part of the political process - may still be required.

\section{(a) Meaning of the word 'Prorogue'}

The word 'prorogue' derives from the latin 'prorogare' to delay. ${ }^{139}$ It comprises a Crown prerogative to command Parliament to suspend its sitting. The effect is to terminate the session of Parliament ${ }^{140}$ and to end any Bill that has not yet received the royal assent.

- However, today, the word 'prorogue' means little in ordinary parlance (and, doubtless, to many MP's and others). Instead, a more modern - and more intelligible - word is to 'suspend'. This also reflects the reality of the situation the sovereign is commanding (ordering) the suspension of Parliament.

- Given this, a Parliament Act should consider employing more modern terminology to describe this function.

Further, the word 'recess' should be applied to both an adjournment and a prorogation, since such occurs in both cases ${ }^{141}$ Parliament recesses; that is, it no longer sits (albeit, the consequence is different).

In conclusion, a more apt (and modern) expression for the proroguing of Parliament is the 'suspending' of Parliament.

\section{(b) Historical Position - 1820 \& 1844}

Prorogation is the suspension of Parliament by order of the sovereign (or her representatives) until Parliament is summoned once more. In respect of the historical position, Chitty (in 1820) stated:

A prorogation...[which] puts an end to the session [of Parliament], and may be termed a continuation [suspension] ${ }^{142}$ of Parliament from one session to another, can, however, be legally effected only by the authority of the king,

\footnotetext{
${ }^{138}$ McBain, $\mathrm{n} 1$, pp $16 \& 70$.

139 e.g. J Wishaw, A New Law Dictionary (1829)(prorogue) 'prorogare, to prolong or put off to another day.' The Oxford Dictionary of English Etymology (ed CT Onions, 1966) (prorogue) 'extend in mind; discontinue the meeting of (a legislative body, etc) XV [15thb century]. Late ME (Middle English] proroge, later, - rogue (XVI)[16th century]...' T Blount, Glossographia (1674) 'Prorogue (prorogo) to prolong, defer, or put off till another day, to continue. As we say, the Parliament is prorogued, when it is put off sine die, but not ended.'

${ }^{140}$ DM Walker, The Oxford Companion to Law (1982) 'An exercise of the royal prerogative by which a session of Parliament is terminated, the Parliament itself continuing in being until dissolved.'

${ }^{141}$ May (2019), n 4, p 164 'The period between the prorogation of Parliament and its re-assembly in a new session is termed a 'recess', while the period between the adjournment of either house and the resumption of its sitting is properly called an 'adjournment' (although in practice the word 'recess' is generally also used in this sense).'

${ }^{142}$ Surely, this word is incorrect? It should be 'suspension'.
} 
expressed either by the Lord Chancellor in [HM's] presence, or by commission from the Crown [i.e. by the Lords Commissioners], or frequently by proclamation. ${ }^{143}$

Thus, as noted, the sovereign can command the suspension of Parliament - whether in person, by writ, commission or proclamation or, indeed, orally. For his part, May (in 1844) stated:

[As] Parliament...can only commence its deliberations at the time appointed by the queen; neither can it continue longer than she pleases. She [the sovereign] may prorogue Parliament by having her command signified, in her presence, by the lord chancellor or speaker of the [HL] to both houses; or by writ under the great seal, or by commission. The effect of a prorogation is at once to suspend all business until Parliament shall be summoned again. Not only are the sittings of Parliament at an end, but all proceedings pending at the time, except impeachments by the commons, are quashed. A bill must be renewed after a prorogation, as if it had never been introduced, though the prorogation be for no more than a day. ${ }^{144}$

\section{(c) Legislative Ability to Shorten or Lengthen a Prorogation}

Legislation enables the sovereign to shorten (accelerate) (see the 1797 Act) or to lengthen (see the 1867 Act) any prorogation. Thus:

- $\quad$ Meeting of Parliament Act 1797. S 1 ([HM] may issue his proclamation for the meeting of Parliament in not less than 14 days from the date) states:

Whenever [HM], his heirs or successors, shall be pleased, by and with the advice of the Privy Council of [HM], his heirs or successors, to issue his or their royal proclamation, giving notice of his or their royal intention that Parliament shall meet and be holden for the dispatch of business on any day after the date of such proclamation, the same shall be a full and sufficient notice to all persons whatever of such the royal intention of [HM], his heirs and successors, and the Parliament shall thereby stand prorogued to the day and place therein declared, notwithstanding any previous prorogation of the Parliament to any longer day, and notwithstanding any former law, usage or practice to the contrary. ${ }^{145}$ (italics provided)

- $\quad$ Prorogation Act 1867. S 1 (power to [HM] to issue proclamation for the prorogation of Parliament) states:

Whenever (save as herein-after excepted) [HM] shall be pleased, by and with the advice of the privy council of $[\mathrm{HM}]$, to issue her royal proclamation to prorogue Parliament from the day to which it shall then stand summoned or prorogued to any further day being not less than [14] days from the date thereof, such proclamation shall, without any subsequent issue of a writ or writs patent or commission under the Great Seal of the [UK], be a full and sufficient notice to all persons whatever of such the royal intention of [HM], and the Parliament shall thereby stand prorogued to the day and place in such proclamation appointed, notwithstanding any former law, usage, or practice to the contrary. ${ }^{146}$ (italics supplied)

S 2 (not to apply to prorogation at the close of a session) states: 'This Act shall not apply to the case of the prorogation of Parliament at the close of a session.'

In respect of this, May (2019) stated:

When Parliament stands summoned (after a dissolution) or prorogued to a certain day, it may be prorogued or further prorogued to a later day, under the [1867 Act], by a proclamation by the queen on the advice of the privy council. The interval prescribed by this Act between the date of the proclamation and the day to which it prorogues Parliament is not less than 14 days. When it is intended that on the day to which it is so prorogued, or further prorogued,

\footnotetext{
${ }^{143}$ Chitty (in 1820), n 5, p 71. He continued 'As the obligation of members to attend arises from writs under the great seal, their discharge from liability to assemble must also flow from the same seal. It seems clear, notwithstanding the opinion of Lord Coke to the contrary, that a prorogation of one house necessarily and tacitly operates as a prorogation of the other. This prorogation may be legally made even at the return of the writ, and before the meeting of Parliament. Thus the Parliament after the general election in the year 1790 was prorogued twice by writ, before it met; and the first Parliament in this reign was prorogued four times, by four writs of prorogation. On the day upon which the writ of summons is returnable, the members of the $[\mathrm{HC}]$ who attend, do not enter their own house or wait for a message from the Lords, but go immediately up to the $[\mathrm{HL}]$, where the Chancellor reads the writ of prorogation. And when it is intended that they should meet upon the day to which the Parliament is prorogued for dispatch of business notice is given by a proclamation. [HM's] assent to a bill during a session does not end it: and it seems that an express prorogation or dissolution is necessary for this purpose. [HM] is entitled to call Parliament together at the end of [14] days from the date of his proclamation for that purpose, notwithstanding any previous prorogation of it to a longer period.'

${ }^{144}$ May (in 1844), n 3, p 35. He continued 'William [III, 1688-1702] prorogued Parliament from the 21st of October 1689, to the 23rd, in order to renew the Bill of Rights [1688], concerning which a difference had arisen between the two houses that was fatal to its progress. As it is a rule that a bill cannot be passed in either house twice in the same session, a prorogation has been resorted to, in other cases, to enable a second bill to be brought in.'

${ }^{145}$ See also Chitty, n 5, p 72. The preamble to the Act was 'An Act to shorten the time now required for giving notice of the royal intention to [HM], his heirs and successors, that Parliament shall meet and be holden for the despatch of business...'.

${ }^{146}$ See also May (in 1844), n 3, p 35.
} 
Parliament shall meet for the dispatch of business, the proclamation states that Parliament will then 'assemble and be holden for the dispatch of divers urgent and important affairs.' Even when Parliament stands prorogued to a specified day 'for the dispatch of business' it may similarly by proclamation be prorogued to a later day. ${ }^{147}$

Also, When Parliament stands prorogued to a certain day, the queen may issue a proclamation [pursuant to the 1797 Act], giving notice of her intention that Parliament shall meet for the dispatch of business on any day after the date of the proclamation; and Parliament then stands prorogued to that day, notwithstanding the previous prorogation. The power cannot be used to advance the meeting day specified in the summons of a new Parliament. ${ }^{148}$ (underlining supplied)

In conclusion, legislation permits the Crown to lengthen or shorten a prorogation.

\section{(d) Current Position}

May (2019) states:

The prorogation of Parliament is a prerogative act of the Crown... The effect of a prorogation is at once to suspend business, including committee proceedings, until Parliament shall be summoned again. Most proceedings still pending at a prorogation are quashed (e.g. questions to ministers, notices of motions, public bills not subject to 'carry over' orders). Some, however, may be suspended and continued with in the new session by decision of either or both houses, and others (e.g. delegated legislation) continue without intervention. In both houses, private and hybrid bills are regularly suspended from one session to another. In the [HC], public bills may also be carried over by order from one session to another, subject to certain restrictions. The Lords have also endorsed the carry-over of public bills in certain circumstances....Parliament is prorogued either by a commission (preceded by a proclamation) or by a proclamation alone. ${ }^{149}$

Parliament was last prorogued by the sovereign in person in $1854 .{ }^{150}$ Thus, today, prorogation by commission or proclamation is used. ${ }^{151}$ In the Supreme Court decision in Miller (2019) the Supreme Court stated as to prorogation:

Parliamentary sittings are normally divided into sessions, usually lasting for about a year, but sometimes less and sometimes, as with the current session, much longer. Prorogation of Parliament brings the current session to an end. The next session begins, usually a short time later, with the Queen's Speech. While Parliament is prorogued, neither house can meet, debate and pass legislation. Neither house can debate government policy. Nor may members of either house ask written or oral questions of ministers. They may not meet and take evidence in committees. In general, Bills which have not completed all their stages are lost and will have to start again from scratch in the next session of Parliament. In certain circumstances, individual cases may be 'carried over' into the next session and pick up where they left off. The government remains in office and can exercise its powers to make delegated legislation and bring it into force. It may also exercise all the other powers which the law permits. It cannot procure the passing of Acts of Parliament or obtain Parliamentary approval for further spending. ${ }^{152}$

In conclusion, the sovereign no longer prorogues Parliament in person. Instead, it is prorogued by commission or proclamation.

\section{(e) Reasons for Prorogation}

In olden times, the Crown prerogative to prorogue was uninhibited. Also, the sovereign did not have to give any reason for commanding the same. Thus, Tudor and Stuart kings frequently prorogued Parliament for long periods and did not give reasons. This is reflected in proclamations issued by Elizabeth I (1558-1603) and James I (1603-25). For example, James I (1603-25) in a Proclamation for Proroguing of Parliament (of 10 January 1608) stated:

'Whereas we did lately prorogue our Parliament till the [10 Feb], we have for divers special causes us moving, thought fit to prorogue the same again until [27 Oct], at [on] which day our purpose is (God willing) to hold the same, and [we] do therefore hereby give notice to all whom it may concern, that they may frame their affairs accordingly, and attend at [on] the same [27 Oct] to that service. ${ }^{153}$ (underlining supplied)

\footnotetext{
${ }^{147}$ Ibid, p 167. See also Anson, n 32, vol 1, p 73. and the Emergency Powers Act 1920 (see now the Civil Contingencies Act 1994).

${ }^{149}$ May (2019), n 4, pp 165-6.

${ }^{150}$ Keith, n 59, p 69 'Not since 1854 has the Crown prorogued Parliament in person.'

${ }^{151} \mathrm{Ibid}, \mathrm{p} 166$.

${ }^{152}$ Miller, n 67, p 394.

153 JF Larkin, Stuart Royal Proclamations (1973), vol 1 (Royal Proclamations of James I 1603-25), p 181.
}

${ }^{148}$ Ibid. Campion (in 1929), n 31, p 107, 'The date to which Parliament stands prorogued may be accelerated in one of the following ways'. He then mentions: (a) by proclamation under the Meeting of Parliament Act 1870 (provided not less than 6 days notice is given), see 5(b); (b) on the demise of the sovereign (Succession to the Crown Act 1707); (c) pursuant to legislation (he referred to legislation relating to the reserves 
As the editors of a text on Stuart Royal Proclamations pointed out, James I (1603-25), likely, prorogued Parliament on the above occasion for a political reason. One which he did not state, since he was not legally obliged to. ${ }^{154}$ On other occasions James prorogued Parliament for reasons such as the:

$$
\begin{aligned}
& \text { - plague, }{ }^{155} \\
& \text { - scarcity of food in London. }
\end{aligned}
$$

There is no doubt that James considered that his power to prorogue was wholly unfettered and needed no reason. Thus, in a Proclamation of 1622 , he stated:

Albeit the assembling, continuing, and dissolving of Parliaments be a prerogative so peculiarly belonging to our imperial Crown, and the times and seasons thereof so absolutely in our own power, that we need not give account thereof unto any: ${ }^{156}$ yet, according to our continual custom, to make our good subjects acquainted with the reasons of all our public resolutions and actions; we have thought it expedient at this time to declare, not only our pleasure and resolution therein, grounded upon mature deliberation, with the advice and uniform consent of our whole privy council; but therewith also to note some especial proceedings moving us to this resolution...' ${ }^{157}$ (underlining supplied)

Elizabeth I (1558-1603) - like James I - in her proclamations indicated no reasons for proroguing Parliament other than general ones. Further, she prorogued Parliament as - and when - she thought fit. ${ }^{158}$

- Thus, it is justly said that Parliament is prorogued etc, at the king's 'pleasure'. ${ }^{159}$ There is no reason to believe that these perceptions (and prerogatives) of Elizabeth I and James I were any different in even earlier times - especially in the reigns of sovereigns up to Richard II (1377-99) who were even more absolute in their rule.

- There is also little support in legal texts for sovereigns not exercising such a right up to the Glorious Revolution of 1688 and much later. Indeed, one would suggest that, until the 1800's, sovereigns got their way in respect of any prorogation of Parliament.

In conclusion, it would seem the Crown prerogative is that the Crown does not have to give any reason for the prorogation of Parliament (nor, indeed, for the dissolution of the same, see 10).

\section{(f) Crown Prerogative to Prorogue Parliament Orally}

At the time of the Norman Conquest, the king and his retainers were illiterate (they could not read or write). Thus, likely, William I (1066-87) opened, dissolved and suspended (prorogued) his assemblies orally. Likely, this custom remained long in continuance and it seems that the sovereign has the prerogative to prorogue (suspend) and dissolve Parliament orally (see also 3(k)). Thus, Hearn, in his Government of England (1886) stated:

\footnotetext{
${ }^{154}$ Ibid, p 181 'One particular reason for further prorogation, which James could not mention here, was that he wanted no discussion or disturbance of the peace negotiations between the Netherlands and Spain, to which he had sent special commissioners'. See also, for example, (Proclamation for Proroguing Parliament 28 December 1620), $\mathrm{p} 497$ 'his Highness [i.e. HM] for divers good causes and considerations him moving, and with the advice of his privy council, has thought good and ncessary to prorogue the said Parliament...' (spelling modernised). See also p 617 (Proclamation for Proroguing Parliament, 19 Jan 1625) 'for waighty [weighty] and important reasons, we...have resolved to prorogue the said Parliament...'. Ibid, p 633 (Proclamation for Proroguing Parliament, 3 March 1625).

${ }^{155}$ Prorogation on account of the plague occured even in the 15th century, see e.g. The Parliament Rolls of Medieval England 1275-1504 (2005), vol 11, p 78 (July 1433). Ibid, p 387, 398 (20 week prorogation from 5 June-20 October 1445 - due to plague, the harvest, and the need for sovereign to be informed of problems). Ibid, two 6 week prorogations in that year (1445).

${ }^{156}$ The Scots Parliament Act 1660, ch 7 (extant) provides much the same: 'The estates of Parliament now convened by his majesty's special authority considering that the quietness, stability and happiness of the people does depend upon the safety of the king's majesty's sacred person and the maintence of his sovereign authority, princely power and prerogative royal and conceiving themselves obliged in conscience in discharge of their duties to almighty God to the king's majesty and to their native country to make a due acknowledgement thereof at this time do therefore unanimously declare that they will with their lives and fortunes mantain and defend the same. And they do hereby acknowledge that the power of calling, holding, proroguing and dissolving of Parliaments and all conventions and meetings of the estates does solely reside in the king's majesty his heirs and successors And that as no Parliament can be lawfully kept without the special warrant and presence of the king's majesty or his commissioner so no acts, sentences or statutes to be past in any Parliament cannot be binding upon the people or have the authority and force of laws without the special authority and approbation of the king's majesty or his commissioner interponed thereto at the making thereof.' (underlining and punctuation supplied)

${ }^{157}$ Larkin, n 153, p 527.

${ }^{158}$ Ibid, p 40 (Proclamation adjourning Parliament from Oxford to Westminster, 15 March 1554) '[HM] for divers great respects and considerations the same now specifically moving, hath by the advice aforesaid [i.e. of the privy council] resolved and determined to adjourn and prorogue her said parliament from the said city of Oxford unto her highness' city of Westminster, and there to be holden and kept.'

${ }^{159}$ e.g. Coke, n 19, vol 4, p 28 'the [HC] is to many purposes a distinct court [i.e. assembly], and therefore is not prorogued, or adjourned by the prorogation or adjournment of the Lord's House [i.e. the HL]: but the Speaker upon signification of the king's pleasure by the assent of the [HC], does say: 'This court does prorogue and adjourn itself.' (spelling modernised).
} 
There is no case other than those I am about to mention where the king acts without the intervention of some officer, whose assistance is essential to the validity of the act and is rendered at his own peril... There are, however, certain cases...which form exceptions to the foregoing rule...In these cases the king does not necessarily require either the assistance or the advice of any officer. He acts in person, and does not merely command actions. The first of these cases is the prorogation or the dissolution of Parliament. Parliament is convened by writs under the great seal, issued, as they always set forth, by the advice of the privy council; but it may be terminated [i.e. dissolved] by the mere oral announcement of the king himself. This mode of dismission is usually adopted for prorogation, unless it be personally inconvenient to $[\mathrm{HM}]$ to attend. A dissolution is now seldom announced in this way, but the power so to dissolve Parliament does not admit of doubt. ${ }^{160}$ (wording underlined)

The use of proclamations (as opposed to writs, commissions or orally) to command prorogation appears to date from the reign of Charles II (1660-85).

In conclusion, it would seem that the Crown prerogative is that the Crown can prorogue (and dissolve) Parliament orally. Given that prorogation is now by way of commission or proclamation (see (d), orally proroguing Parliament should be dispensed with.

\section{(g) Crown Prerogative to Prorogue Parliament for Long Periods}

Up to 1688 and beyond, sovereigns - especially, those who had a fraught relationship with Parliament - prorogued the same for long periods, only calling them again when they ran out of money. Later examples may be found in Hatsell, Precedents of Proceedings in the House of Commons ( $2^{\text {nd }}$ ed, 1785) which covers the period 1665-1738. ${ }^{161}$ However, these long periods of prorogation have been curtailed dramatically in recent times. Thus, in Miller (2019), the Supreme Court noted:

The usual length of a prorogation was under ten days, ${ }^{162}$ though there had been longer ones. The present proposal would mean that Parliament stood prorogued for up to 34 calendar days but, given the conference recess, the number of sitting days lost would be far less than that. ${ }^{163}$

Although the Supreme Court did not, then, state the exact number of days, it also referred to a government Memo of 15 August 2019 which referred to 7 possible sitting days (excluding the Conference season recess). ${ }^{164}$ The Supreme Court also referred to the:

- $\quad$ NI (Executive Formation etc) Act 2019, s 3 which lays down a 5 calendar day period. ${ }^{165}$

- $\quad$ evidence of a former Prime Minister (John Major) ${ }^{166}$ that work on a Queen’s speech normally took 4-6 days. ${ }^{167}$

However, no reference was made to a 5 day period under the Civil Contingencies Act 1994, s 28 (re the issue of emergency regulations). ${ }^{168}$ Evidence was also provided to the Supreme Court (by the advocate general for Scotland) of a couple of long periods in the $20^{\text {th }}$ century respect of prorogation:

\footnotetext{
${ }^{160}$ WE Hearn, The Government of England. Its Structure and Development (1886), $\mathrm{p} 98$.

${ }^{161}$ Hatsell (in 1785), n 23, pp 233-40. In part prorogations were longer in order to take account of the time needed for MP's to travel to Parliament from the far parts of England. This was 40 days and, after the union with Scotland, 50 days, see Ibid and $\mathrm{n} 75$.

${ }^{162}$ It is unclear whether the reference is to 10 days or 10 sitting days; there is a big difference. One presumes, the reference is to the latter. However, since no detailed summary was provided by the clerks of Parliament as to the length of prorogations, this is unclear.

${ }^{163}$ Miller (2019), n 67, p 398.

${ }^{164} \mathrm{Ibid}$, 'a maximum of seven days were lost apart from the time usually set aside for the conference recess'. See also p 381 (advocate general for Scotland) 'maximum of seven sitting days'). Also, Cherry IH, n 67, p 1101, per Lord Carloway, 'Although the planned prorogation would be 34 days, the expected conference recess of three weeks would mean that only one to three days would be lost in a week commencing 9 September and four in the week commencing 7 October.'

${ }^{165} \mathrm{~S}$ 3(4) 'If, as a result of Parliament standing prorogued or adjourned, a Minister of the Crown cannot comply with the obligations in [ss] (2) or (3), a proclamation under the Meeting of Parliament Act 1797 shall require Parliament to meet on a specified day within the period within which compliance with [ss] (3) is required and to meet on the [5] following days (other than Saturdays, Sundays or a day which is a bank holiday in the [UK] or in any part of the [UK]) to allow for compliance with [ss] (3).'

${ }^{166}$ John Major was PM from 1990-7.

${ }^{167}$ Miller (2019), n 67, p 409. Also, 'Sir John's evidence is that he has never known a government to need as much as five weeks to put together its legislative agenda.' Cf. Re the Crown prerogative and its use, per John Major 'it is for individual ministers to decide on a particular occasion whether and how to report to Parliament on the exercise of prerogative powers.' 220 HC Official Report (6th series) col 19, cited in Munro, n 43, p 276.

${ }^{168}$ Civil Contingencies Act 1994, s 28 (Parliamentary scrutiny: prorogation and adjournment) '(1) If when emergency regulations are made under [s] 20 Parliament stands prorogued to a day after the end of the period of [5] days beginning with the date on which the regulations are made, [HM] shall by proclamation under the Meeting of Parliament Act 1797 (c. 127) require Parliament to meet on a specified day within that period. (2) If when emergency regulations are made under [s] 20 the [HC] stands adjourned to a day after the end of the period of [5] days beginning with the date on which the regulations are made, the Speaker of the $[\mathrm{HC}]$ shall arrange for the house to meet on a day during that period. (3) If when emergency regulations are made under [s] 20 the [HL] stands adjourned to a day after the end of the period of [5] days beginning with the date on which the regulations are made, the speaker of the $[\mathrm{HL}]$ shall arrange for the house to meet on a day during that
} 
- 18 Sept-16 Oct 1914 - 53 days

- 1 August $1930-87$ days. ${ }^{169}$

For its part, in Cherry IH (2019), Lord Carloway (of the Scots Inner House) noted a HC library briefing paper which stated that the duration of prorogation in recent times had been 'very short'. And that, since the 1980s, prorogation had rarely lasted longer than 2 weeks (and, between sessions, it had been less than a week). ${ }^{170}$ Thus, the issue facing the Supreme Court (and the Scots courts) was a simple one. In modern times, is a prorogation of 7 sitting days too long? It is clear that these courts thought so - even though, even in the 1980's prorogation was, often, 2 weeks or more. Contrariwise, the Court of Appeal in $R$ (On the Application of Gina Miller) $v$ the Prime Minister (2019) stated:

It was impossible for the court to make a legal assessment of whether the duration of the prorogation was excessive by reference to any measure. Parliament may be prorogued for various reasons, including 'to gain a legislative and so political advantage.'

For the purpose of this article, it is unnecessary to opine on whether the opinion of the Supreme Court or the Court of Appeal is a more accurate factual position. However, it was unfortunate that a summary of the durations of prorogations from (say), at least, 1880 was not provided to these courts, in order for a measure of relativity to be accorded (see 7(b)).

In conclusion, the Crown prerogative can prorogue Parliament for long periods - subject only to any limitation imposed by legislation (i.e. for 3 years, see 7(b)). However, the Miller (2019) judgment suggests that a prorogation of more than 7 sitting days may be problematic.

\section{(h) Prorogation distinct for HC and HL}

The proroguing of the HC and the HL was distinct. Thus, Coke noted:

the $[\mathrm{HC}]$ is to many purposes a distinct court [assembly], and therefore is not prorogued, or adjourned by the prorogation or adjournment of the Lord's house [i.e. the HL]: but the Speaker, upon signification of the king's pleasure by the assent of the [HC], does say: 'This court does prorogue and adjourn itself' and then it is prorogued or adjourned, and not before (spelling modernised). ${ }^{171}$

In conclusion, prorogation should apply to both houses of Parliament.

\section{(i) Suggested Modern Position}

Given the uncertainty as to the meaning of the word 'prorogation' - and the fact that it and the word 'adjournment' were synonyms - it may be appropriate to conflate these two words into one word ('suspension'). Also, that there be just one section in a Parliament Act to deal with the 'suspension' of Parliament by: (a) Parliament; and (b) the sovereign. Distinct from this are the following proposed modernisations:

- $\quad$ Proclamations. A Parliament Act should provide for any prorogation to be effected by proclamation only (i.e. as stated in the 1867 Act) and the proroguing of Parliament by the sovereign in person - as well as by means of the Lord Commissioners, orally or by written message (whether under the great seal or the sign manual) should be abolished as obsolete. Proclamations should, also, be capable of being issued electronically.

- Proclamations applying to both Houses at the same time. Any prorogation by the HC should automatically apply to HL (in the past, one could be prorogued and not the other).

- Limiting Occasions and Times to Prorogue in any one Year. If Parliament is required to meet for a specified number of days each year (say, 200-250 days, see 7), then, it may be appropriate to limit the occasions and times in which Parliament may be prorogued. For example, for 3 times a year only. And, for (say) up to 14 days each time. On other occasions, adjournment would be appropriate;

- $\quad$ Remove the effect of Prorogation on Bills. It may be appropriate to remove the effect of prorogation - so that it is the same as in the case of adjournment. That is, so that prorogation does not terminate the session (or any bill not yet concluded). ${ }^{172}$

period. (4) In [ss] (2) and (3) a reference to the Speaker of the [HC] or the speaker of the [HL] includes a reference to a person authorised by standing orders of the $[\mathrm{HC}]$ or of the $[\mathrm{HL}]$ to act in place of he speaker of the $[\mathrm{HC}]$ or the speaker of the $[\mathrm{HL}]$ in respect of the recall of the house during adjournment.'

${ }^{169}$ Miller (2019), n 67, p 381.

${ }^{170}$ Cherry $I H, \mathrm{n} 67, \mathrm{p} 1100$.

${ }^{171}$ Coke, n 19, p 28 (see n 159). Cf. Bowyer (in 1846), n 35, p 97 'Both houses are prorogued together, because it is not a prorogation of one house, but of the Parliament.'

${ }^{172}$ A Twomey, The Veiled Sceptre (2018), p 584, n 4 'in some countries, such as New Zealand, India and Malaysia, bills do not lapse upon prorogation.' 
- $\quad$ Crown Prerogative. In any case, any Crown prerogative to reduce (or increase) the duration of a prorogation should be abolished.

The position as to the demise of the Crown during prorogation has been previously discussed in the context of a Crown Act and does not seem to be problematic. ${ }^{173}$

\section{CROWN PREROGATIVES - DISSOLUTION}

\section{(a) Historical Position - Dissolution in Person}

Chitty noted (in 1820):

As the power of convening and proroguing Parliament is vested by the constitution, that is, by the common law, and by the custom of Parliament, in the king, so [HM] possesses, on similar grounds, the power of dissolving it. This can only be done in the king's presence, either in person or by representation [i.e. by commission]. ${ }^{174}$ (italics supplied)

Chitty then noted, on the subject of dissolving Parliament in person, that Mr Evans (in his text on Parliamentary Debates) had made following observations:

Some thought that the dissolution of Parliament by the Prince Regent in person [in 1818] was ungracious, and that it was intended as a mark of dis-satisfaction. It certainly appears that, in former times, a dissolution in person was considered an offensive act in the sovereign. On the $10^{\text {th }}$ March, 1629, the day to which both Houses were adjourned, king Charles I [1625-49] came to the [HL], and without sending for the Commons, spoke as follows;

'My Lords - I never came here upon so unpleasant an occasion, it being the dissolution of a Parliament; therefore men may have some cause to wonder why I should rather not choose to do this by commission; it being rather a general maxim with kings to leave harsh commands to their ministers, themselves only exercising pleasing things.'

And then, after some words, [Charles I] directed the Lord-Keeper to dissolve the Parliament. The entry on the Lords' journal is - ipse dominus rex hoc praesens Parliamentum dissolvit. On $28^{\text {th }}$ of March, 1681, king Charles II [166085] suddenly dissolved the Parliament then sitting at Oxford. His speech was as follows;

'My Lords and gentlemen - that all the world may see to what a point we are come, that we are not like to have a good end, when the divisions at the beginning are such: therefore, my Lord Chancellor, do as I have commanded you.'

Then the Lord Chancellor said

'My Lords and gentlemen - [HM] has commanded me to say, that it is his royal pleasure and will, that this Parliament be dissolved; and this Parliament is dissolved'.

Bishop Burnet (Hist of Own Times, v 1 p 499) ${ }^{175}$ gives the following account of this dissolution

By the steps which the Commons [the $\mathrm{HC}$ ] had taken, the king saw what might be expected from them; so, very suddenly, and not very decently, he came to the [HL], the Crown being carried between his feet, in a sedan: and he put on his robes in haste, without any prior notice, and called up the Commons, and dissolved the Parliament; and went with such haste to Windsor, that it looked as if he was afraid of the crowds that this meeting has brought to Oxford.

In these two instances, the dissolution in person was thought indecent and offensive. It is true that the Parliament of 1660 - the Convention Parliament, which restored king Charles II [1660-85] - was dissolved by the king in person; but then $[\mathrm{HM}]$ had sent a message to the [HL] some days before to signify his intention, which message was communicated by them to the Commons, and a conference was holden upon it. The message was as follows:

[HM] hath expected, ever since Thursday morning, to be informed that his two houses of Parliament had been ready to present such bills to him as they had prepared for his royal assent, and hath continued ever since in the same expectation, and hoped that he might have this day finished the work and dissolved them according to his signification; but, being informed that there are yet depending in both houses some few bills of great importance to his and the public service, which are not ready to be presented to him; and being desirous to part with his two Houses of Parliament, who have deserved so well of him, in such a manner, that they may not be obliged to use more expedition in the despatch than is agreeable ; and to the affairs which are to be dispatched, $[\mathrm{HM}]$ is graciously pleased to declare, that he will be ready to pass such bills as are necessary, in point of time, to be passed, on Monday morning; and then, that the houses adjourn

\footnotetext{
${ }^{173}$ McBain, n 1, pp 16 \& 70.

${ }^{174}$ Chitty, n 5, p 72. See also May (in 1844), n 3, p 142 (process when the sovereign attends).

${ }^{175} \mathrm{G}$ Burnet, History of his own Times (1724-34).
} 
until Thursday, so that they may have that day and Friday to put an end to those most public bills which are not yet finished; and this [HM] will, on the next day, being Saturday the $29^{\text {th }}$ of this month, be present with them, and dissolve the Parliament; and [HM] desires both houses, against that time, to lay aside all business of private concernment to finish all public bills.

Since the [Glorious] revolution [in 1688], Parliament has been always dissolved by proclamation, ${ }^{176}$ after having been first prorogued. The dissolution, therefore, by the Prince Regent in person was an unusual proceeding; but it does not appear, from any thing that was said or done, that it was meant to be offensive. It was adopted merely for the sake of dispatch. ${ }^{177}$

Thus, the last time the sovereign dissolved Parliament in person was in 1818.

\section{(b) Power of the Sovereign in respect of Dissolution}

As to the power of the sovereign in respect of dissolution (and the same applies in relation to the opening of parliament and its prorogation) by Victorian times, it seems to have been (clearly) accepted that the sovereign did not, in person, have the executive power to:

- $\quad$ refuse a dissolution desired by the government; or to ${ }^{178}$

- compel a dissolution independently. ${ }^{179}$

The above issues were explored by Victoria during her reign. However, she never defied her governments in respect of them (doubtless, aware of the constitutional consequences). Nor did her successors. ${ }^{180}$ Thus, the Crown prerogative to dissolve Parliament became formal one long ago (a 'legal fiction'). That is, by Victorian times, it was accepted that the sovereign could not act against the advice of her government to dissolve Parliament. Nor could she unilaterally dissolve Parliament. As Keith (in 1936) stated:

All royal official actions must be done, under the principles of the modern constitution, on the final authority of a minister of the Crown or the Cabinet, the authority of the ministers being derived from the fact that they command the support of the majority for the time being in the $[\mathrm{HC}] .^{181}$

Finally, Parliament was (usually) prorogued prior to its dissolution. However, it did not have to be. ${ }^{182}$

In conclusion, the power of the sovereign to dissolve Parliament had become a formal power by Victorian times.

\section{(c) Current Position}

In Miller (2019), the Supreme Court stated:

The dissolution of Parliament brings the current Parliament to an end. Members of the [HC] cease to be members of Parliament. A general election is then held to elect a new [HC]. The government remains in office but there are conventional constraints on what it can do during that period. These days, dissolution is usually preceded by a short period of prorogation. Dissolution used also to be a prerogative power of the Crown but is now governed by the Fixed Term Parliaments Act 2011. This provides for general elections to be held every [5] years and for an earlier election to be held in two circumstances:

\footnotetext{
${ }^{176}$ May (in 1844), n 3, p 37 'Parliament is usually dissolved by proclamation, after having been prorogued to a certain day.'

${ }^{177}$ Chitty, n 5, pp 72-3.

${ }^{178}$ Keith, n 59, p 140 'Needless to say, the power to dissolve Parliament cannot be exercised without ministerial advice. The necessary machinery presumes ministerial aid, but the king may refuse to dissolve when advised, and if he deems a dissolution necessary in the public interest he may urge such a course on ministers, and, if they will not accept his suggestion, he may compel their resignation or dismiss them from office, and appoint ministers who will arrange a dissolution.' However, see pp 143-4 (Lord Aberdeen (PM from 1852-5) to Queen Victoria in 1852, he 'never entertained the slightest doubt that, if the minister advised the queen to dissolve [Parliament], she would, as a matter of course, do so.' See also p 149 (in 1874) 'the Queen...though warning him [Gladstone] the dissolution...was likely to prejudice the standing of government, accepted the advice of cabinet on the score [ground] that an election was necessary to clarify the position.' Also, $p$ 152 (in 1886, Lord Salisbury (PM, 1885-6, 1886-92, 1892-1902) to Queen Victoria). For George V (1910-36) (refusing to refuse a dissolution in 1910) see Keir, n 100, p 494. Also, in respect of Victoria. Ibid, p 492.

${ }^{179}$ Ibid, p 156 (in 1892, Lord Salisbury to Queen Victoria), 157-9 (in 1884). Keith, n 59, pp 158-9 'The Queen [Victoria] dropped the project, but the fact that she ever entertained it is eloquent of her failure to realise the just limits of her authority. Her claim amounted to the proposition that she was entitled at her discretion to secure a dissolution on an emergent issue before it had ever been debated by Parliament. It is hardly necessary to insist that such a claim was incompatible with responsible government.' M MacDonagh, The English King (1929), pp 202-3 'The reign of Queen Victoria....shows that she was able to exercise but little influence in really great and vital affairs of state. We see her not so much controlling as criticising the work of her ministers.'

${ }^{180}$ Ibid, pp 159-82.

${ }^{181} \mathrm{Ibid}, 61-2$.

${ }^{182}$ Campion, n 31, p 75 'The prorogation of Parliament is the usual preliminary to its dissolution. In 1922, however, the proclamation dissolving Parliament was issued at a time when both houses stood adjourned.'
} 
either the $[\mathrm{HC}]$ votes, by a majority of at least two thirds of the number of seats (including vacant seats) in the house, to hold an early election;

or the $[\mathrm{HC}]$ votes that it has no confidence in [HM's] government and no one is able to form a government in which the house does have confidence within 14 days.

Parliament is dissolved 25 days before the polling day and cannot otherwise be dissolved. The Act expressly provides that it does not affect [HM's] power to prorogue Parliament: section 6(1). ${ }^{183}$ (wording divided for ease of reference).

\section{(d) Suggested Modern Position}

Today, legislation (see 10) governs the dissolution of Parliament. However, such is controversial and, in any case, legislation should abolish the Crown prerogative to dissolve Parliament. ${ }^{184}$ Or, if such a Crown prerogative returns - the Fixed Term Parliaments Act 2011 being altered - then, dissolution should be by way of a proclamation only since dissolution in person is now obsolete (and Lords Commissioners are not required).

In conclusion, a Parliament Act should provide for the dissolution of Parliament by proclamation (assuming any change to the Fixed Term Parliament Act 2011 which revives any Crown prerogative).

\section{CASE OF MILLER (2019)}

The Supreme Court decision in Miller (2019) - holding that a prorogation of Parliament for up to 7 sitting days, was unlawful in the circumstances - does not need to be considered in great detail in this article since the latter is proposing what the law should be. Not what it is asserted it presently is. However, some useful points may be made:

\section{(a) Nature and Scope of the Crown Prerogative re Prorogation}

This case - and the prior Scots and Court of Appeal decisions leading up to it - show great uncertainty as to the nature, and scope, of the Crown prerogative in respect of prorogation. Such is troubling since the issue is, relatively, simple. And, after hundreds of years, it ought to be pretty clear cut. Not least, to assist democracy.

As it is, Miller (2019) has not been able to clarify matters much. In light of this, it would seem compelling that this Crown prerogative is abolished and statutory provision be made instead. This also applies to the related issues of adjournment - as well as the opening, and meeting, of Parliament

In conclusion, the exercise of the Crown prerogative in respect of the opening, adjourning and proroguing of Parliament is opaque and uncertain. Thus, legislation to clarify matters is essential.

\section{(b) Role of the Crown - A Legal Fiction}

In Miller (2019) the Supreme Court was concerned to prevent the sovereign (the Crown in person) being involved in politics. It stated:

It is not suggested in these appeals that $[\mathrm{HM}]$ was other than obliged by constitutional convention to accept that advice [from the PM as to prorogation]. In the circumstances, we express no view on that matter. ${ }^{185}$

However, this is somewhat coy. ${ }^{186}$ Today, it seems abundantly clear that - unlike in Tudor and Stuart times - the Crown no longer exercises executive power. Thus, the sovereign no longer takes executive decisions on government (political) matters. Rather, she acts under advice. And, she must accept the same. Such an event had already occurred by Victorian times in respect of all Crown prerogatives relating to Parliament. A simple chart elicits the following:

$\underline{\text { Act }}$

HC privileges

Speaker

\section{Last time the sovereign:}

refused to confirm privileges of the $\mathrm{HC}$

1514 (never) $^{187}$

$1678^{188}$

\footnotetext{
${ }^{183}$ Miller, n 67, p 395.

${ }^{184}$ The Fixed Term Parliaments Act 2011 did not expressly abolish the prerogative to dissolve. However, Crown prerogatives must be expressly abolished, in order for the same to occur.

${ }^{185}$ Mliler, n 67, p 401.

${ }^{186}$ See also Cherry IH, n 67, p 1115, per Lord Brodie 'In reality the sovereign never acts by himself, but only through the medium of ministers or executive servants and accordingly a challenge to an order in council is properly directed against the responsible ministers or their law officer.'

${ }^{187}$ There never seems to have been a case when the sovereign refused to confirm the privileges (Cf. James II (1603-25) indicated that he did so as a matter of grace (royal condescention)). Even before 1514, there was a reference to privileges for speakers, see e.g. Pronay, n 23, p 201 (referring to the Modus Tenendi Parliamentum c. 1320). Ibid, Parliament Rolls, n 155, vol 11, p 11 (May 1432) 'to have and exercise each and every kind of other liberties as fully and as freely as any such speaker had had in the past.'

${ }^{188}$ See $\mathrm{n}$ 24. D Chalmers \& C Asquith, Outlines of Constitutional Law (1922), p 216 noted 'The king may refuse to accept the choice of the Commons as to electing a speaker but by convention he never does so.'
} 


\begin{tabular}{|c|c|c|}
\hline Royal assent & refused to give royal assent & $1707^{189}$ \\
\hline HL debates & asserted a right to attend debates & pre- $1714^{190}$ \\
\hline Adjournment & gave permission (consent) to Parliament to adjourn & $1814^{191}$ \\
\hline \multirow[t]{2}{*}{ Opening } & refused to open Parliament against government advice & pre- $1837^{192}$ \\
\hline & demanded to open Parliament against government advice & pre- $1837^{193}$ \\
\hline \multirow[t]{3}{*}{ Dissolution } & dissolved Parliament in person & $1818^{194}$ \\
\hline & refused to dissolve Parliament against government advice & pre $-1837^{195}$ \\
\hline & dissolved Parliament against government advice & pre- $1837^{196}$ \\
\hline Prorogation & prorogued Parliament in person & $1854^{197}$ \\
\hline Address & sought to challenge the government wording of an address & $1881^{198}$ \\
\hline Peace & refused to consent to a peace treaty (including cession of land) & pre- $1904^{199}$ \\
\hline
\end{tabular}

Against this background it seems obvious that the role of the sovereign in respect of the summoning, opening, meeting, prorogation, adjournment and dissolution of Parliament is, now, purely formal. ${ }^{200}$ That is, the presence of the Crown is no more than a legal fiction and such has been the position since late Victorian times (effectively, by 1881). More particularly, the above comprises a compelling case for legislation - recognising the realities of the situation.

In conclusion, the involvement of the sovereign in respect of the assembling of Parliament has been a legal fiction since, at least, Victorian times. Such have become government (political) prerogatives. Thus, legislation should clarify the true position.

\section{(c) Failure of Counsel to Provide Factual Detail}

Surely, all counsel should be criticised for failing to provide basic data on the historical duration of prorogation, to the Supreme Court - data contained in a list? After all, the crucial issue in this case was whether the duration of prorogation was excessive at 7 sitting days. Yet, all counsel failed to do this. Why?

- The Parliament Rolls (online, with word search and in hardcopy) would have enabled a list to be drawn up of the duration of all prorogations (as well as the opening, dissolution and adjournment) of Parliament in the period 12751504. Also, Hatsell lists various prorogations in the period 1665-1738, in his well known work, Precedents of Proceedings in the House of Commons. There is a also a text (anonymous) listing out prorogations of Parliament from the reign of Henry III (1216-72) to $1690 ;{ }^{201}$

- Further, the clerks of Parliament could have (without difficulty) provided a list of the durations of prorogations from (say) 1880 .

As it is, in older times (i.e. pre-Victoria) the Crown prorogued Parliament for long periods. In some cases, for years. And, its right to do was not challenged, even under the 1694 Act. True, times may have changed and the period should be reduced. However, it would seem better that legislation effect this - as opposed to the courts struggling to alight on a particular number. Further, it is quite insufficient for a court to have to rely only the evidence of one Prime Minister who was in office for a short period (1990-7). While useful such fails to present an accurate appraisal of a Crown prerogative to prorogue Parliament - a prerogative which has been exercised for hundreds of years. This is not to say that the outcome of the Supreme Court judgment would not have been the same. However, everyone would have been better informed. So too, if reference had been made to

\footnotetext{
${ }^{189}$ See n 220.

${ }^{190}$ See n 33 (reign of George I (1714-27). Wade \& Phillips, n 6, p 15 'his [the sovereign's asssent] has been a formality since the days when the principle of ministerial responsibility to Parliament became developed.'

${ }^{191}$ May (in 1844), p 36 (1 March 1814).

192 There appears to be no instance afer the reign of Victoria and it unclear whether there is any prior to 1688.

193 Ibid.

${ }^{194}$ May (in 1844), p 37 (10th June 1818).

${ }^{195}$ See n 178.

${ }^{196}$ See n 179.

${ }^{197}$ See n 150.

${ }^{198}$ See $n 251$.

${ }^{199}$ Keith, n 59, p 246-8 (Anglo-French treaty of 1904 which involved cession of territory).

${ }^{200}$ In Cherry $\mathrm{OH}, \mathrm{n}$ 67, p 1072 per Lord Doherty 'It is common ground that in making the order [HM] accepted that advice.'

${ }^{201}$ See Parliament Rolls, n 155. Also, GO Sayles, The Function of the Medieval Parliament of England (1988) (list from 1258-1348). See also Anon, Table of the Commencement, Adjournment, Prorogation and Dissolution of Parliaments (1690).
} 
the maximum duration of prorogations in other Commonwealth countries which have adopted the Westminster model. Thus, Twomey (2018) states:

There is usually a time limit upon how long Parliament can be prorogued. This arises from a provision that has traditionally been included in Constitutions derived from the Westminster system of government - that there must be a session of Parliament at least every 12 months ${ }^{202}$ or a shorter period. ${ }^{203}$ This means that Parliament cannot be prorogued for any longer than that stipulated period and any advice to do so would be unconstitutional. ${ }^{204}$

In light of the durations of prorogation in other Westminster-based constitutions, a 7 sitting day maximum prorogation seems (very) short.

In conclusion, the durations of prorogation over the centuries should have been listed - enabling the Supreme Court to have an accurate means of comparison.

\section{(d) Crown Prerogative - No Requirement to Give Reasons}

In the time of the Tudors and Stuarts, sovereigns - when proroguing Parliament - indicated they were not required to give reasons. ${ }^{205}$

- There was a good legal basis for this. Sovereigns could never be required to explain their reasoning since they were not justiciable in their courts. Such immunity remains the position today. Thus, in the case of Miller (2019), Cherry $\mathrm{OH}$ (2019) or Cherry IH (2019) if the Queen had been requested to submit an affidavit - or to appear in the witness box - and declined, doubtless, the court would not have compelled her; ${ }^{206}$

- Further, such applies in relation to any Crown prerogative - not just to prorogation. ${ }^{207}$ Thus, for example, it applies to the war and peace prerogatives (also, to the cession of land).

A further difficulty is that if a minister (including the PM) is required to give evidence - or reasons - in respect of a Crown prerogative by a court this exposes the reality that the role of the sovereign is, today, a legal fiction. One unsuited to modern times in the case of Crown prerogatives (especially, in the context of c. $85 \%$ of all Crown prerogatives being obsolete).

- Given this, it would seem sensible (indeed, imperative) that Crown prerogatives be now recognised for what they are - Government (i.e. political) prerogatives. And, that the same now be placed in legislation, to the extent still required (most, in any case, are not contentious).

- As it is, one of the grounds for justiciability in the Miller (2019) case appears to be that the courts required a good reason $^{208}$ for the PM to prorogue Parliament for 7 sitting days or more. However, this seems to avoid the fact that the Crown prerogatives to prorogue (and dissolve) Parliament (as well as to consent to an adjournment) were, in the past, exercised by sovereigns for the most naked political (and personal) reasons and that - even when seemingly good reasons were given - they were (often) a cloak to more covert desires. ${ }^{209}$

True, it may be that times have changed and that - the sovereign's role now being formal - it is appropriate that politicians act in a more morally upright manner than sovereigns formally did. Yet, the courts becoming so involved could lead them into policing Parliament - with a result the courts are resorted to by politicians as a political tactic. The slope is a slippery one. The courts becoming involved in ever more nuanced decisions. For example, is a 10 sitting day prorogation allowed in the case

\footnotetext{
${ }^{202}$ Twomey, n 172, p 592. Reference is made to the constitutions of Australia, Bahamas, Kiribati, Malta, Mauritius, Nauru, St Lucia, Samoa, Solomon Islands and Tuvalu.

${ }^{203}$ Ibid. Reference is made to the consititutions of Barbados, Belize, Dominica, Fiji, Grenada, Guyana, India, Jamaica, Malaysia, Pakistan (3 sessions a year and no more than 120 days between sessions), St Kitts and Nevis (180 days), St Vincent and Grenadines, Singapore, Sri Lanka ( 2 months), Trinidad and Tobago. All these constitutions stipulated 6 months, save where stated. Even in the case where a government did not hold the confidence of the lower house, prorogations were long e.g. Sri Lanka (2001, prorogation of 3 months), Canada (2008), Turks \& Caicos (2009, almost 4 months, Grenada (2012, 10 months), Guyana (2014-5, 5 months).

${ }^{204} \mathrm{Ibid}, \mathrm{p} 586$.

${ }^{205}$ See 9(e).

${ }^{206}$ Also, a difficult position could arise if the evidence of the sovereign contradicted that of her minister. Such could easily bring the sovereign into the political arena and incure dis-repute.

${ }^{207}$ Cherry IH n 67, p 1110 per Lord Brodie 'there is remarkably little said about the reason for the prorogation in the respondent's pleadings. Although a court would not expect an affidavit from a government minister or official testifying to the reason...it would expect averments in the respondent's answers setting out that reason.' Ibid, per Lord Drummond Young at $\mathrm{p} 1126$ 'In my opinion nothing in these documents can be said to provide any rational explanation as to why Parliament must be prorogued as early as 9 September for a period of five weeks.'

${ }^{208}$ e.g. Cherry IH, n 67, per Lord Drummond Young, p 1125 'The tenor of these comments [of the PM] suggests a desire to excuse the length of the prorogation.' Ibid, per Lord Brodie, at p 1119 'when the manoeuvre is quite so blatantly designed 'to frustrate Parliament' at such a critical juncture in the history of the [UK] I consider that the court may legitimately find it to be unlawful.'

${ }^{209}$ See n 154 (James II). See also Parliament Rolls, n 155, vol 11, p 236 (1439 'A prolongation as close to Christmas as 21 December might suggest that the government had prolonged the session for as long as possible in the hope of persuading the Commons to agree a tax grant.'
} 
where the situation is not politically charged but only 5-7 days if it is? And, is a reason a good reason when a variety of factors are involved?

In conclusion, all Crown prerogatives in respect of Parliament which are not otherwise obsolete (of which there are very few) should be spelt out in legislation if ministers are to be held justiciable for exercising them since - for legal reasons (the immunity of the sovereign) - the sovereign cannot confirm/deny any role, despite discussing these matters with a PM.

\section{(e) Failure to Note Essential Matter}

The Fixed Term Parliaments Act 2011 (the '2011 Act') was intended to make statutory provision on a fixed term for Parliament (5 years) and on its dissolution. Section 6(1) expressly provides that the Act does not apply to the prorogation of Parliament. ${ }^{210}$ Further, the 2011 Act did not seek to repeal the Meeting of Parliament Act 1694, s 1 of which now only applies to prorogation or adjournment. Section 1 states:

... a parliament shall be held once in 3 years at least (see 7).

Therefore, within the 5 year term of Parliament under the 2011 Act, under the 1694 Act the maximum period for which Parliament may be prorogued (or adjourned) is, actually, 3 years. In other words, Parliament may adjourn itself for up to 3 years. Or, the government may prorogue Parliament for up to 3 years. True, in reality, the period is 1 year (or less) since Parliament must meet every year to enable government to be funded. However, such does not affect the legal and practical reality that - pursuant to the 1694 Act - Parliament may be prorogued (or adjourned) for up to 1 year and such is not unlawful. Further, the 1694 Act does not stipulate (no legislation on the assembly of Parliament ever has) that any reason(s) have to be given for prorogation (see (d) above). Thus, was the 1694 Act adequately explained to the Scots and English courts? One wonders. In particular, Scots counsel and judges would (understandably) have little background knowledge of the operations of Parliament or early Eng;lish legislation - especially, prior to the respective Scots and English Acts of Union 1706-7. ${ }^{211}$

\section{(f) Coach and Horses}

The Supreme Court decision in Miller (2019) was a difficult decision for any court - since it was dependent on particular facts and circumstances arising against a stormy political background. However, on any account, the decision is not a solution since it leaves open other means of avoiding a prorogation of more than 7 sitting days.

- For example, there is nothing to stop a government from proroguing Parliament for a few days and, then, using its statutory power under the Prorogation Act 1867, s 1, to extend that prorogation for, at least, 14 days (see 9(c)). That is, to lengthen the period of prorogation. And, there seems to be no limit to this - save for the 3 year period in the 1694 Act (see above).

- Further, any prorogation of more than 7 sitting days would now seem to be a positive invitation to a political party(ies) to litigate the same. It also creates an anomaly in that adjournment can be a far more extended period and, yet, the maximum period of prorogation (by judicial fiat) now appears to be only 7 sitting days. Yet, these words were synonyms once (see 8(a)).

- Further, it seems to leave open the argument that the courts in Miller (2019) were mis-led over the legal nature of the 1694 Act which was manifestly designed to cover lacunae in the 1640 and 1664 Acts - lacunae which the wily Charles II (1660-85) and his brother, James II (1685-8), were happy to exploit.

In conclusion, in order to prevent the courts becoming embroiled in disputes in respect of the maximum number of days permitted for the prorogation of Parliament in particular fact situations - legislation should clarify matters. For everyone.

\section{(g) $\underline{\text { Conclusion }}$}

Miller (2019) is useful since it shows how out of date the law is in the area of Parliament. And, that the legal fiction as to the executive power of the sovereign in respect of all Crown prerogatives belies the reality. Such has transmuted into a formal role and this has been the case for, at least, 100 years. The solution would seem simple. Pass modern (intelligible) legislation, sweeping away dead law. Thus, a Parliament Act should provide for the following:

- Parliament must meet each year (it has done, in practice, since 1694 at least);

- Parliament must meet for a stipulated number of days a year (such is required due to the huge volume of business); ${ }^{212}$

- All Crown prerogatives concerning the summoning, opening, meeting, adjourning, proroguing and dissolving of Parliament should be placed in legislation;

\footnotetext{
${ }^{210}$ Miller (2019), n 67, p 395.

${ }^{211}$ The Union was never intended to change anything to do with the assembly and operation of the English Parliament which had operated since, at least, 1285 (with the Commons) and as a great council, at least, back to the Norman Conquest (1066). Further, the Scots Claim of Right 1689 was designed to mirror the English Bill of Rights 1688.

${ }^{212}$ This also helps prevent mis-use of adjournment and prorogation.
} 
- All common law Crown prerogatives should be abolished (it is suggested most are obsolete);

- The maximum number of days to adjourn or prorogue Parliament should be stipulated;

- The Fixed Term Parliament Act 2011 should be repealed (and, perhaps, the former system re-adopted); ${ }^{213}$

- The English High Court should have jurisdiction in respect of a Parliament Act. ${ }^{214}$

\section{CROWN PREROGATIVES - TERM OF PARLIAMENT}

The Fixed Term Parliaments Act 2011 ('FTPA') states: ${ }^{215}$

- $\quad \mathrm{S} 1$ (polling days for parliamentary general elections). (1) This [s] applies for the purposes of the timetable in rule $1 \mathrm{in} \mathrm{[sch]} 1$ to the Representation of the People Act 1983 and is subject to [s] 2. (2) The polling day for the next parliamentary general election after the passing of this Act is to be 7 May 2015. (3) The polling day for each subsequent parliamentary general election is to be the first Thursday in May in the fifth calendar year following that in which the polling day for the previous parliamentary general election fell. (4) But, if the polling day for the previous parliamentary general election - (a) was appointed under [s] 2(7), and (b) in the calendar year in which it fell, fell before the first Thursday in May, [ss] (3) has effect as if for "fifth" there were substituted "fourth". (5) The $[\mathrm{PM}]$ may by order made by $[\mathrm{SI}]$ provide that the polling day for a parliamentary general election in a specified calendar year is to be later than the day determined under [ss] (2) or (3), but not more than [2] months later. (6) A [SI] containing an order under [ss] (5) may not be made unless a draft has been laid before and approved by a resolution of each House of Parliament. (7) The draft laid before Parliament must be accompanied by a statement setting out the [PM's] reasons for proposing the change in the polling day.

- $\quad \mathbf{S} 2$ (early parliamentary general elections). (1) An early parliamentary general election is to take place if - (a) the [HC] passes a motion in the form set out in [ss] (2), and (b) if the motion is passed on a division, the number of members who vote in favour of the motion is a number equal to or greater than two thirds of the number of seats in the house (including vacant seats). (2) The form of motion for the purposes of [ss] (1)(a) is - "That there shall be an early parliamentary general election." (3) An early parliamentary general election is also to take place if - (a) the HC passes a motion in the form set out in [ss] (4), and (b) the period of 14 days after the day on which that motion is passed ends without the House passing a motion in the form set out in [ss] (5). (4) The form of motion for the purposes of [ss] (3)(a) is - "That this house has no confidence in [HM's] Government." (5) The form of motion for the purposes of [ss] (3)(b) is - "That this house has confidence in [HM's] Government." (6) [ss] (7) applies for the purposes of the Timetable in rule 1 in [sch] 1 to the Representation of the People Act 1983. (7) If a parliamentary general election is to take place as provided for by [ss] (1) or (3), the polling day for the election is to be the day appointed by $[\mathrm{HM}]$ by proclamation on the recommendation of the [PM] (and, accordingly, the appointed day replaces the day which would otherwise have been the polling day for the next election determined under [s] (1).

- $\quad \mathbf{S} 3$ (dissolution of Parliament). (1) The Parliament then in existence dissolves at the beginning of the 25th working day before the polling day for the next parliamentary general election as determined under [s] 1 or appointed under [s] 2(7). (2) Parliament cannot otherwise be dissolved. (3) Once Parliament dissolves, the Lord Chancellor and, in relation to [NI], the Secretary of State have the authority to have the writs for the election sealed and issued (see rule 3 in [sch] 1 to the Representation of the People Act 1983). (4) Once Parliament dissolves, [HM] may issue the proclamation summoning the new Parliament which may- (a) appoint the day for the first meeting of the new Parliament; (b) deal with any other matter which was normally dealt with before the passing of this Act by proclamations summoning new Parliaments (except a matter dealt with by [ss] (1) or (3)) $)^{216}$

Other sections comprise ss 4 and 5 (general election for the Scottish Parliament and the National Assembly for Wales not to fall on the same day as the Parliamentary general election under s 1(2)); s 6 (supplemental), s 7 (final provisions). Given that

\footnotetext{
${ }^{213}$ That is, the government having a right to dissolve and go to the country. Since there is (often) a considerable risk in this (as the past has shown), a disolution cannot be said to be policy weapon that is, inevitably, to the benefit of a government in power.

${ }^{214}$ Parliament has always sat in England (though not necessarily in Westminster). Further, its practices and procedures since medieval times have evolved against the background of the common law and the physical logistics of summoning, opening etc reflect the same (use of writs of summons etc). Thus, to prevent forum shopping - and to bring on cases of constitutional importance as soon as posible - it would seem best to have the English High Court deal with such matters.

${ }^{215}$ See also May (2019), n 4, pp 163-4.

${ }^{216}$ See also (5) 'In this [s] "working day" means any day other than - (a) a Saturday or Sunday; (b) a Christmas Eve, Christmas Day or Good Friday; (c) a day which is a bank holiday under the Banking and Financial Dealings Act 1971 in any part of the [UK]; (d) a day appointed for public thanksgiving or mourning. (6) But, if - (a) on a day ("the relevant day") one or more working days are fixed or appointed as bank holidays or days for public thanksgiving or mourning, and (b) as a result, the day for the dissolution of a Parliament would (apart from this [ss]) be brought forward from what it was immediately before the relevant day to a day that is earlier than 30 days after the relevant day, the day or days in question are to continue to be treated as working days (even if the polling day is subsequently changed).'
} 
this Act is now a political issue of consequence, it is not proposed to analyse this Act in this article. However, one wonders whether the FTPA has worked in practice. Indeed, the Septennial Act 1715 was much simpler. And, it worked.

In conclusion, a Parliament Act should make provision on the maximum term permitted before the requirement to call a general election.

\section{CROWN PREROGATIVES - ROYAL ASSENT}

\section{(a) Historical Position}

Chitty (writing in 1820) stated:

The discretionary power of assenting or dissenting to an Act of Parliament is, in England, a high and incommunicable prerogative; though it may be communicated to the governor of a colony, with respect to the acts of a colonial assembly.

The royal assent to a bill (which cannot be given previous to a meeting of Parliament, any more than the dissent can be effectually expressed after the session has ended), is proclaimed before the two houses, assembled in the Lords' House [i.e. the HL], either by the king in person, or by letters patent under the great seal, signed by [HM], and declared and notified in his absence, to the Lords and Commons.

Before the assent is given, the titles of the Acts, which have passed both Houses, are read; whereupon, the clerk of the Parliament expresses the assent or dissent. In the case of the royal assent to a public bill, the clerk usually declares, 'le roy le veut', to a private bill, 'soit fait comme il est desire'. If the king refuse his assent, the words used are 'le roy s'avisera'. When a bill of supply is passed, it is carried up and presented to the king, by the Speaker of the [HC], and the royal assent is thus expressed 'le roy remercie ses loyal subjects, accepte lour benevolence, et aussi le veut' - the king thanks his loyal subjects, accepts their benevolence, and wills it be so to be. ${ }^{217}$ It is not usual, except in the case of an act of grace, for statutes to originate with the king; but, without doubt, if a bill, with the royal assent, should be sent to the Lords and Commons, and receive their assent also, it would be a perfect law, if even in the form of a charter, as was the case with Magna Carta. That which constitutes law is the concurring assent of all the branches of the legislature, wheresoever it may originate, whatever may happen to be the form of it. ${ }^{218}$

For his part, May (writing in 1844) stated:

When bills have been finally agreed to by both houses, they await only the royal assent to give them, as Lord Hale says, 'the complement and perfection of a law' 219 and from that sanction they cannot legally be withheld. For this purpose they remain in the custody of the clerk of the enrolments, in the [HL], except money bills, which are returned to the Commons before the royal assent is given; and when several have accumulated there, or when the royal assent is required to be given without delay to any bill, the lord chancellor has notice that a commission is wanted... When the Queen comes in person to give her royal assent, the clerk assistant of the Parliaments waits upon [HM] in the robing room before she enters the house, reads a list of the bills, and receives her commands upon them. During the progress of a session, the royal assent is generally given by a commission issued under the great seal for that purpose.

The first instance in which the royal assent appears to have been given by commission, was in the $33^{\text {rd }}$ of Henry 8 [1541]; although proceedings very similar had occurred in the $23 \mathrm{~d}$ and $25^{\text {th }}$ years of the reign [i.e. 1531 and 1533] of that king... The form in which the royal assent is signified by commission is as follows - Three or more of the lords commissioners, seated on a form between the throne and the woolsack in the [HL], commands the usher of the Black Rod to signify to the Commons that their attendance is desired in the House of Peers [HL] to hear the commission read, upon which the Commons with the speaker immediately come to the bar. The commission is then read at length, and the titles of the bills being afterwards read by the clerk of the Crown, the royal assent is signified by the clerk of the Parliaments in Norman French.... The form of words used to express a denial of the royal assent would be 'La reyne s'avisera'. The necessity of refusing the royal assent is removed by the strict observance of the constitutional principle, that the Crown has no will but that of its ministers; who only continue to serve in that capacity so long as they retain the confidence of Parliament. This power was last exercised in 1707, when Queen Anne refused her assent to a bill for settling the militia in Scotland. During the Commonwealth the lord protector gave his assent to bills in English; but on the Restoration, the old form of words was reverted to, and only one attempt has since been made to abolish it. In 1706, the lords passed a bill 'for abolishing the use of the French tongue in all proceedings in Parliament and the courts of justice.' This bill dropped in the [HC]; and although an Act was passed

\footnotetext{
${ }^{217}$ Chitty, n 3, p 3 'Laws are said to be enacted 'by the king's most excellent majesty, by and with the advice and consent of the Lords Spiritual and Temporal and Commons in Parliament assembled.'

${ }^{218}$ Ibid, pp 74-5. See also Hatsell (in 1785), n 23, pp 241-8.

${ }^{219}$ M Hale, The Jurisdiction of the Lords House or Parliament (1796), p 9 'But as to making of laws, the king's le roy le voet [the king wills] or some equivalent gives it the complement and perfection of a law.'
} 
in 1731 for conducting all proceedings in courts of justice in English, no alteration was made in the old forms used in Parliament.

The royal assent is rarely given in person, except at the close of a session, when the Queen attends to prorogue the Parliament, and then she signifies her assent to such bills as may have passed since the last commission was issued; but the bills for making provision for the honour and dignity of the Crown, such as the bills for settling the civil lists, have generally been assented to by the Queen in person, immediately after they have passed both houses. When $[\mathrm{HM}]$ gives her royal assent to bills in person, the clerk of the Crown reads the titles, and the clerk of the Parliaments makes an obeisance to the throne, and then signifies [HM's] assent in the manner already described. A gentle inclination, indicative of assent, is given by [HM], who has, however, already given her commands to the clerk assistant, as shown above. ${ }^{220}$

\section{(b) Current Position}

Today, the sovereign no longer gives the royal assent in person. It does so by commission. May (2019) states:

Into the custody of the Clerk [of the Parliaments] are also placed bills that have passed through both houses and await the royal assent and the Clerk is responsible for the preparation of the texts of the Acts of Parliament. At the ceremony of the royal assent to bills by commission, the Clerk pronounces to each Act the words by which the royal assent is signified and has the duty by statute to endorse on every Act the date on which it received the royal assent. ${ }^{221}$

In respect of the Crown prerogative to assent to Parliamentary bills today ${ }^{222}$ consideration should be given to abolishing the:

- Requirement of royal assent (or of the Crown's power to refuse assent);

- Anglo-norman language employed in the declaration of royal assent.

As to these:

- $\quad$ Abolishing Need for the Assent. The role of the sovereign is now a formal one and royal assent has not been refused since 1707. ${ }^{223}$ Thus, there are grounds for abolishing this requirement ${ }^{224}$ and for legislation to provide that all bills shall declare (as a term thereof) that they shall take effect as Acts (and - in the absence of such a term - they shall automatically take effect, on (say) $12 \mathrm{pm}$ on the day the bill passed both houses).

- $\quad$ Abolishing Refusal to Assent. If the requirement for royal assent is not abolished then - given the supremacy of Parliament - consideration should be given to legislation preventing an otherwise valid bill from taking effect by the Crown dissenting (i.e. refusing assent). Something which has not occurred since 1707 and which would, likely, provoke a constitutional crisis.

- Abolishing the Anglo-Norman Language. Finally, in all cases, it would help ordinary people to understand the Parliamentary process, if the macerated Anglo-Norman words presently employed to signify assent, are translated into modern English as 'The sovereign assents'. And, that this wording be employed regardless of whether the bill is a general, private or hybrid one. Or whether it is a bill of supply or not.

In conclusion, a Parliament Act should provide that the sovereign cannot refuse to exercise the Crown prerogative to give the royal assent (alternatively, abolishing the need for royal assent). Further, English wording should, in any case, be used to signify the royal assent.

\section{MODERNISING PARLIAMENTRY PRIVILEGES - FREEDOM OF ELECTION}

The Bill of Rights 1688, s 1(8) states:

\footnotetext{
${ }^{220}$ May (in 1844), n 3, pp 291-5. Ibid, n 2 'This power was last exercised in 1707, when Queen Anne [1702-14] refused her assent to a bill for settling the militia in Scotland.'

${ }^{221}$ May (2019), n 4, p 123.

${ }^{222}$ Halsbury, Laws of England (5th ed), vol 20, para 52 'The monarch, together with the [HC] and [HL], is one of the three components of Parliament, and her formal assent to a parliamentary bill is required before it can have force of law. This remains one of the monarch's direct prerogative powers of a ceremonial nature, which only she, or a commission authorised by her, may exercise. It is routinely performed on the advice of the Prime Minister or responsible minister, and by convention the monarch retains no personal discretion or independent judgement in granting the assent.' See also Chitty (in 1820), n 5, p 74.

${ }^{223}$ Chitty (in 1820), n 5, p 3 'the constitution...has assigned to the king a share in legislation: this purpose is sufficiently ensured by placing in the Crown the negative power of rejecting suggested laws. The royal legislative right is not of the deliberative kind; the Crown has no power to propound laws...'. For comparative data on the royal assent, see Twomey, n 172, ch 9.

${ }^{224}$ Chitty (in 1820), n 5, p 3 noted that the sovereign could withhold 'his assent at pleasure, and without stating any reason, to the enactment of provisions tending to their prejudice.' However, cf. Keith, n 59, p 203, Advice of Lord Rosebery [PM 1894-5] in 1913 (to refuse to assent to a bill would be unconstitutional and a coup d'etat). Ibid, pp 204-5. Ibid, p 247 'It is true that Edward VII [1901-10] would not have vetoed a bill but neither did Queen Victoria, and though he had never forced a dissolution, his mother equally had never actually done so.' RFV Heuston, Essays on Constitutional Law (1964), p 67, 'the royal assent is given on the advice of ministers and it is inconceivable that a monarch would refuse it since the development of the doctrine of responsible government.'
} 
That [the] election of members of Parliament ought to be free.

It is suggested this be re-stated in a Parliament Act - with slight amendment in order to reflect the true meaning, viz. that 'the election of MP's must be freely made.' In the case of peers, there is no election.

\section{MODERNISING PARLIAMENTARY PRIVILEGES - FREEDOM OF SPEECH}

The privilege of freedom of speech in Parliament is referred to in 2 Acts:

\section{(a) Strode's Act 1512 (also, called the Privilege of Parliament Act 1512)}

This was, actually, a temporary, local Act relating to certain specific individuals and it has little to do with any general privilege of Parliament. Its purport (if anything) was better contained in the Bill of Rights 1688, s 9 (see (b) below). The wording of this Act is unintelligible unless considered with regard to the background to the same. The material wording ${ }^{225}$ provides as follows (suits against any for bills or speeches \&c. in Parliament declared void. Action on the case given to the party grieved: treble damages, \&c. schedule, above referred to).

And that suits, accusations, condemnations, executions, fines, amercements, punishments, corrections, grievances, charges and impositions put or had or hereafter to be put or had unto or upon the said Richard [Strode] and to [i.e. on] every other of the person or persons afore specified, that now be of this present parliament or that of any parliament hereafter shall be for any bill speaking reasoning or declaring of any matter or matters concerning [i.e. in] the parliament to be commenced ${ }^{226}$ and treated of, be utterly void and of no effect.

And that if the said Richard Strode or any of all the said other person or persons hereafter be vexed, troubled or otherwise charged for any causes as is aforesaid, that then he or they and every [one] of them so vexed or troubled of and for the same to have action upon the case against every such person and persons so vexing or troubling any contrary to this ordinance and provision, in the which action the party grieved shall recover treble damages and costs.

$\mathrm{Be}$ it inquired for our sovereign lord the king that whereas at the parliament holden at Crockerentor [Crockern Tor] before Thomas Denys, Deputy to Sir Henry Marney, knight, Warden of the Stannary, the [ $24^{\text {th }}$ September 1510$]$ it was ordained, established and enacted that from the day aforesaid it shall be lawful for every man to dig tin within the county of Devonshire in all places where as tin may be found; and also to carry the water to other works without any let or trouble of any person or persons according to our usages and confirmation and our charter and according to our custom out of mind: and if any person or persons let trouble or vex any man to dig tin or to carry water for the same contrary to our old custom and usage and if it be found by verdict of 12 men at the lawday, he that so lets, vexes or troubles any such person or persons shall fall in the penalty of $£ 40$ as ought [i.e. as often] as he so vexes or troubles the one half to my lord prince [i.e. the duke of Cornwall] and the other half to him that was so let, vexed or troubled, and a fieri facias to be awarded as well for my lord prince as for the party, if one Richard Strode of Plympton, tinner at the parliament held at Westminster the $\left[5^{\text {th }}\right.$ February 1510$]$ let, vexed or troubled one William Rede the younger and Elys [Elias] Elford, tinners and all other tinners in the same parliament [i.e. the Westminster Parliament] for digging of tin in the several soil of the said Richard and other persons contrary to this our Act made.

The material part of this Act is in para 1, with wording of especial importance underlined. However, it seems (fairly) clear that this Act seeks to declare that any punishment imposed on Strode et al only (see underlined wording) by any Devon stannary court as a result of pursuing his 4 Bills in Parliament (see underlined wording above) was to be void and of no effect (triple damages also being payable). This Act is considered in detail in an article. ${ }^{227}$ As for the background to the Act:

- In 1512, Richard Strode (MP for Plympton in Devon) brought 4 Bills in the [HC], to seek to protect the Western harbours in Plympton from damage caused by tin miners. For bringing such bills, certain Devon stannary (tin mining) courts (abolished in Victorian times) issued a judgment condemning Strode to pay a fine and to put up a bond (he was also imprisoned for non-payment of the former, for 3 weeks).

- Strode petitioned Parliament to void the judgment. This it did, holding that all 'suits, accusations, executions, amercements, corrections, charges and impositions' [in the stannary courts] on any MP for any 'bill, speaking, reasoning or declaring of any matters concerning Parliament' would be held void (see above). However, this (likely) was only intended to give immunity to Strode (and named others) from judgments of these stannary courts in respect of Strode et al continuing to pursue their 4 Bills in Parliament. It was not intended to, generally, provide for freedom of speech in Parliament. ${ }^{228}$

\footnotetext{
225 The Act is set out in full in Halsbury's Statutes $\left(4^{\text {th }}\right.$ ed), vol 10(1). However, the gravamen of this Act is provided in the Government website of legislation.

${ }^{226}$ Probably, the word is 'communed' (i.e. discussed).

${ }^{227}$ GS McBain, Abolishing some Obsolete Constitutional Legislation (2011) Coventry LJ, vol 16, issue 1, pp 12-5.

${ }^{228}$ Cf. May (in 1844), n 4, pp 78-9. He stated 'The words of the statute also leave no doubt that it was intended to have a general operation in future, and to protect all members, of either house, from any question for [i.e. questioning of] their speeches or votes in Parliament.' However,
} 
In any case, the Bill of Rights 1688, s 1(9) (see below) was (and is) more general and wider in its formulation, such that this Act of 1512 is no longer required.

\section{(b) Bill of Rights 1688, s 9(1)}

The Bill of Rights 1688, s 1(9) states:

That the freedom of speech and debates or proceedings in Parliament ought not to be impeached [i.e. challenged] or questioned in any court or place out [i.e. outside] of Parliament. ${ }^{229}$

This wording is more extensive than the 1512 Act. It is suggested that this be re-stated in a Parliament Act, with slight amendment in order to reflect its true meaning, viz. that the

Freedom of speech and debates or proceedings in Parliament shall not be challenged or questioned in any court or place outside Parliament. ${ }^{230}$

As to the meaning of the word 'proceedings' in this article, the Supreme Court in Miller (2019) indicated that such did not comprise a prorogation. It was not a decision of either the HL or HC. Rather, it was something imposed on them from outside (one would agree). ${ }^{231}$

In conclusion, a Parliament Act should provide for freedom of speech in Parliament, employing language similar to that in the Bill of Rights 1688, but modernized. The Acts of 1512 and 1688 should be repealed.

\section{MODERNISING PARLIAMENTRY PRIVILEGES - ARREST \& IMPRISONMENT}

The privilege of MP's and peers from freedom from arrest (and imprisonment) is referred to in 3 Acts, ${ }^{232}$ viz.

- $\quad$ Privilege of Parliament Act 1603. This enabled execution for debts owed to be brought against persons who had privilege of Parliament, when the privilege ended. It is of no real practical effect today. This Act is entitled 'An Act for new executions to be sued against any which shall hereafter be delivered out of execution by privilege of Parliament and for the discharge of them out of whose custody such persons shall be delivered.' S 1 (execution may be renewed against persons discharged by privilege of Parliament, when they cease to be privileged) states:

Forasmuch as heretofore doubt has been made, if any person being arrested in execution, and by privilege of either of the houses of Parliament set at liberty, whether the party at whose suit such execution was pursued be for ever after barred and disabled to sue forth a new writ of execution in that case: for the avoiding of all further doubt and trouble which in like cases may hereafter ensue,

from henceforth the party at or by whose suit such writ of execution was pursued, his executors or administrators, after such time as the privilege of that session of Parliament in which such privilege shall be so granted shall cease, may sue forth and execute a new writ or writs of execution, in such manner and form as by the law of this realm he or they might have done if no such former execution has been taken forth or served:

and from henceforth no sheriff, bailiff or other officer from whose arrest or custody any such person so arrested in execution shall be delivered by any such privilege, shall be charged or chargeable with or bv any action whatsoever for delivering out of execution any such privileged person so as is foresaid, by such privilege of Parliament set at liberty; any law, custom or privilege heretofore to the contrary notwithstanding.

this (it is suggested) is contrary to the factual position surrounding the Act. That said, a resolution of the HC on 12 November 1667 also resolved that Strode's Act was a general one. However, such appears to be an ex post facto rationalisation not based on the actual facts. See also Hatsell, n 23, vol 1 (1785), pp 85-7, 206-7, 218. Also, Coke, n 19, vol 4, p 9.

${ }^{229}$ Ibid, May (in 1844), n 3, p 80.

${ }^{230}$ In Scotland, the Claim of Right 1689 sought to replicate this wording, stating 'That for the redress of all grievances and for the amending, strengthening and preserving of the laws Parliaments ought to be frequently called and allowed to sit and the freedom of speech and debate secured to the members.' (spelling modernised). See Miller (2019), n 67, p 410.

${ }^{231}$ Miller (2019), n 67, p 411 'The prorogation itself takes place in the [HL] and in the presence of members of both houses. But it cannot sensibly be described as a 'proceeding in Parliament'. It is not a decision of either house of Parliament. Quite the contrary: it is something which is imposed upon them from outside. It is not something upon which [MPs] can speak or vote. The [Lords] Commissioners are not acting in their capacity as members of the [HL] but in their capacity as royal commissioners carrying out the Queen's bidding. They have freedom of speech. This is not the core or essential business of Parliament. Quite the contrary: it brings the core or essential business of Parliament to an end.'

${ }^{232}$ See also May (in 1844), n 3, ch 5. 
Provided always, that this Act or any thing therein contained shall not extend to the diminishing of any punishment to be hereafter by censure in Parliament inflicted upon any person which hereafter shall make or procure to be made any such arrest as is aforesaid.

- $\quad$ Parliamentary Privilege Act 1737. In times when persons could be arrested and imprisoned for debt in many instances, this Act provided that - in any legal process brought by (or on behalf of) the Crown to recover a debt against: (a) a peer of the realm, the same could not be 'arrested or imprisoned' for a Crown debt; or (b) against an MP - the same could not be arrested or imprisoned 'during the continuance of the privilege of Parliament'. This Act is entitled 'An Act to amend an Act passed in the Twelfth and Thirteenth Year of the Reign of King William the Third, intituled "An Act for preventing any Inconveniences that may happen by Privilege of Parliament." (the reference is to 12 \& 13 Will $3 \mathrm{c} 3$, rep). Section 1 (no process against the king's debtor to be stayed by privilege of Parliament; but the persons not to be arrested) states (the pertinent wording is underlined):

And it is hereby enacted. that no action, suit, process, order, judgement, decree, or proceeding in law or equity against the king's original and immediate debtor, for the recovery or obtaining of any debt or duty originally and immediately due or payable unto [HM], his heirs or successors, or against any accountant or person answerable or liable to render any account unto [HM], his heirs or successors, for any part or branch of any of his or their revenues, or other original and immediate debt or duty, or the execution of any such process, order, judgement, decree, or proceedings, shall be impeached [i.e. challenged], stayed, or delayed in any court in [GB] or Ireland, by or under the colour or pretence of any privilege of the Parliament of [GB]; yet so nevertheless that

the person of any such debtor or accountant or person answerable or liable to account, being a peer or lord of Parliament of [GB], shall not be liable to be arrested or imprisoned by or upon any such suit, order, judgement, decree, process, or proceedings,

or being a member of the [HC] of [GB], shall not, during the continuance of the privilege of Parliament, be arrested or imprisoned by or upon any such order, judgement decree, process, or proceedings.

Parliamentary Privilege Act 1770. This Act was not limited to Crown debts. It emphasized that privilege of Parliament could not be pleaded in order to delay civil legal and judicial (court) proceedings against peers and MPs (and their servants, the latter now being obsolete). ${ }^{233}$ In particular, this Act referred to their being sued in various courts. However, this Act, s 2, also provided a general exemption from arrest or imprisonment in the case of MP's in any civil process. This Act is entitled 'An Act for the further preventing delays of justice by reason of privilege of Parliament. ${ }^{234}$ It states:

S 1 (suits may be prosecuted in Courts of Record, Equity, or Admiralty, and Courts having Cognizance of Causes Matrimonial and Testamentary, against Peers, and Members of the House of Commons, and their Servants, \&c). 'Any person or persons shall and may at any time commence and prosecute any action or suit in any court of record or court of equity or of admiralty, and in all causes matrimonial and testamentary, in any court having cognizance of causes matrimonial and testamentary, against any peer or lord of Parliament of [GB], or against any of the knights, citizens, and burgesses, and the commissioners for shires and burghs of the $[\mathrm{HC}]$ of [GB] for the time being, or against their or any of their menial or any other servants, or any other person intitled to the privilege of Parliament of [GB]; and no such action, suit, or any other process or proceeding thereupon shall at any time be impeached, stayed, or delayed by or under colour or pretence of any privilege of Parliament.

$\mathrm{S} 2$ (but the persons of members of the [HC] not to be arrested or imprisoned). Provided nevertheless, that nothing in this Act shall extend to subject the person of any of the knights, citizens, and burgesses, or the commissioners of shires and burghs of the $[\mathrm{HC}]$ of $[\mathrm{GB}]$ for the time being, to be arrested or imprisoned upon any such suit or proceedings.

\footnotetext{
${ }^{233}$ May (in 1844), n 3, p 84 'the latter [i.e. their servants] have, at present, no privilege whatever.'

${ }^{234}$ The preamble is:'Whereas the several laws heretofore made for restraining the privilege of Parliament with respect to actions or suits commenced and prosecuted at any time from and immediately after the dissolution or prorogation of any Parliament until a new Parliament should meet, or the same be reassembled, and from and immediately after an adjournment of both houses of Parliament for above the space of [14] days, until both houses should meet or assemble, are insufficient to obviate the inconveniences arising from the delay of suits by reason of privilege of Parliament, whereby the parties often lose the benefit of several terms: for the preventing all delays the king or his subjects may receive in prosecuting their several rights, titles, debts, dues, demands, or suits for which they have cause...'.
} 
It may be readily seen that these Acts of 1603, 1737 and 1770 are couched in a (very) antiquated language. They also relate to a time when the arrest and imprisonment of debtors for a debt was common. Today, arrest and imprisonment for a debt (or any civil process) is rare. ${ }^{235}$ Also, May (in 2019) candidly admits:

the privilege of freedom from arrest...is now highly unlikely to be exercised.... [it] is now confined to civil arrest and is of extremely limited application. Both the 1999 and 2013 Joint Committees on Parliamentary Privilege recommended its abolition, although the 2013 Committee noted that the likelihood of the privilege arising was extremely remote, and its abolition would require legislation. (italics supplied)

One would agree with the statement 'extremely remote'. Further, if retained, it would seem more appropriate to limit any immunity of peers and MP's from arrest and imprisonment to any civil process against them when physically present (located) within the precincts of Parliament - the real intention of these antiquated Acts being not to disrupt the business of Parliament ${ }^{236}$ (and any 40/50 day duration of the privilege of freedom from arrest being obsolete). ${ }^{237}$ Further, this privilege in respect of arrest and imprisonment should only, in the case of the HL, apply to peers sitting in Parliament. In this respect, May (in 2019) notes:

In addition to privilege of Parliament, which is enjoyed by all members of the [HL], whether they are bishops or peers, there is a separate privilege of peerage, which extends to all peers, whether or not they have seats in the [HL], including peers who are minors, and also to wives and widows of peers... The extent of the privilege of peerage is not entirely clear, but it has been shown in recent times to confer immunity from arrest on civil process. The Joint Committee on Parliamentary Privilege in 1999 recommended its abolition. ${ }^{238}$

Thus, a Parliament Act might state something to the following effect (if retained): ${ }^{239}$

(1) No MP, or peer sitting in Parliament, shall be subject to arrest and/or imprisonment in respect of any civil:

(a) process; or

(b) legal proceedings,

while physically within the precincts of Parliament, save that such privilege shall not otherwise delay (a) or (b). ${ }^{240}$

In conclusion, a Parliament Act should provide for the freedom of members of Parliament from arrest and/or imprisonment while within the precincts of the same, with these antiquated Acts being repealed.

\section{MODERNISING PARLIAMENTRY PRIVILEGES - ACCESS, CONSTRUCTION}

It is said that there is a privilege of MP's - and members of the HL - to have access to the sovereign.

\section{(a) Historical Position - Access}

However, May (in 1844) was somewhat dismissive of this and, indeed, evidence of any legal or customary right to have access to the sovereign is scant. Thus, he stated:

The privilege of access is not enjoyed by individual members of the [HC], but only by the house at large, with their speaker; and the only occasion on which it is exercised is when an address is presented to [HM] by the whole house... The only right claimed and exercised by individual members, in availing themselves of access to [HM], is that of accompanying the speaker with addresses, and entering the presence of royalty, in their ordinary attire. Such a practice is, perhaps, scarcely worthy of notice, but it is probably founded upon the concession to the [HC] of a free access to the throne, which is supposed to entitle them, as members, to dispense with the forms and ceremonies of the court. Far different is the privilege enjoyed by the [HL]. Not only is the house, as a body, entitled to free access

\footnotetext{
${ }^{235}$ It does not apply to any criminal process. May (in 1844), n 3, p 104 'The privilege of freedom from arrest has always been limited to civil causes, and has not been allowed to interfere with the administration of criminal justice.' See also May (2019), n 4, p 279 'not confined to civil arrest.'

${ }^{236}$ The original limitation of the privilege seems clearly intended to prevent members of Parliament being impeded from getting to Parliament and returning home, see e.g. May (in 1844), n 3, pp 96-7, 100-1. Ibid, p 110 'the personal privilege of members, and the ancient privilege of their servants...were founded upon the necessity of enabling members freely to attend to their duties in Parliament.'

${ }^{237}$ May (2019), n 3, p 286

${ }^{238}$ Ibid, p 241. In 1929, Campion, n 31, p 40 (quoting Maitland) said 'Freedom from arrest is now no very important matter, because this immunity does not extend to imprisonment on the charge of an indictable offence, and in 1869 imprisonment for debt was abolished.' Munro, n 43, p 219 thought this privilege 'had lost most of its importance.' Maitland, n 43, p 377 'Freedom from arrest is now no very important matter, because this immunity does not extend to imprisonment on the charge of an indictable offence, and in 1869 imprisonment for debt was abolished.'

${ }^{239}$ It is suggested this privilege be abolished. The occasions in which it arises are now (very) rare and its original purpose (to enable execution for debt) has gone.

${ }^{240}$ Such a formulation preserves the respective spheres of Parliamentary privilege and the jurisdiction of the courts, see also May (2019), $\mathrm{n} 4$, $\mathrm{p} 335$, fn 5 (re freedom of speech).
} 
to the throne, but each peer, as one of the hereditary counsellors of the Crown, is individually privileged to have an audience of $[\mathrm{HM}] .^{241}$

\section{(b) Current Position - Access}

May (2019) states:

The privilege of freedom of access is exercised by the $[\mathrm{HC}]$ as a body and through their speaker. The [HC] attends the Queen on summons to the [HL], for purposes prescribed by [HM]. Out of Parliament, the [HC] exercises its right of access for the purpose of presenting addresses, which may deal with any subject of public policy chosen by the house. Such an address may be presented by the whole house or, more usually, by such members as have access to the $[\mathrm{HM}]$ as privy counsellors or as members of [HM's] household. On occasion, the house has ordered that the address be presented by certain specified members. The right of access to [HM], so that the queen receives only the decisions of the house as a whole and cannot take notice of matters pending in the house, still less of debates or the speeches of individual members... The [HL], like the [HC], is entitled to access to the sovereign, as a body, and peers in addition possess the right of access as individuals, as part of the privilege of peerage. ${ }^{242}$

Historically, there is little evidence that individual members of the HC or HL have demanded access to the sovereign. Or, that such would have been granted - even if they had done so.

- Further, given the large membership of the HC and HL today, it would not seem appropriate or feasible leaving aside considerations of safety etc. Thus, any individual privilege should be abolished - albeit, it is dubious any such 'privilege' has (in truth) ever existed. ${ }^{243}$

- $\quad$ As to the two instances in respect of the HC, viz. (a) at the opening of Parliament (when the sovereign attends); and (b) when presenting addresses, the first is purely formal since the $\mathrm{HC}$ is commanded to attend the sovereign (thus, it cannot be termed a 'privilege'). And, the second is rare and only a few selected individuals are usually involved.

\section{(c) Favourable Construction}

As for the 'privilege' of the sovereign favourably construing the proceedings of the HC, this cannot be said to be such. At most, it is a courtesy. One which is not legally binding. May noted in 1844:

That all the proceedings of the $[\mathrm{HC}]$ may receive from $[\mathrm{HM}]$ the most favourable construction, is conducive to that cordial co-operation of the several branches of the legislature which is essential to order and good government; but it cannot be classed among the privileges of Parliament. It is not a constitutional right, but a personal courtesy; and if not observed, the proceedings of the house are guarded against any interference, on the part of the Crown, not authorised by the laws and constitution of the country. The occasions for this courtesy are also limited; as by the law and custom of Parliament the queen cannot take notice of anything said or done in the house, but by the report of the house itself. ${ }^{244}$

In conclusion, a Parliament Act should end any privilege (right) of access by individual MPs - and members of the HL - if there ever was one. As to corporate access and favourable construction, the former would seem unnecessary to make legislative provision for. And the latter should be dispensed with (even as a courtesy) since there is little legal basis for it (further, the sovereign can only take notice of HC's proceedings, anyway, by report).

\section{ABOLISHING OBSOLETE PARLIAMENTARY LEGISLATION}

There are various pieces of legislation relating to Parliament which should be abolished as obsolete. These comprise the following:

- Bearing of Armour Act 1313. This legislation provides that men shall come to Parliament without 'all force' and 'armour,' and, in effect, makes the same a crime. In 1312, the earls of Lancaster, Hereford, Pembroke and Warwick

\footnotetext{
${ }^{241}$ May (in 1844), n 3, pp 46-7. Hatsell, n 23, vol 1 (1785), p 76 suggest that the first reference to a privilege of access may be to the reign of Elizabeth I (1558-1603).

${ }^{242}$ May (2019), n 4, p 251-2. Hatsell, n 23, vol 1, p 76 noted generally 'what is the extent of these privileges [of Parliament], and how long, their duration, has been always uncertain, and frequently a matter of dispute; nor are these points settled even at present, except in those particular instances where Acts of Parliament, or the resolution of either house of Parliament, have ascertained and defined them.'

${ }^{243}$ For example, both George I (1714-27) and Victoria (1837-1901) were notorious for 'cutting' any MP or peer they disliked and, it is (surely) very likely that a demand for access (how could it have been enforced?) would have ensured social isolation. In 1829, Lord Eldon [Lord Chancellor 1801-6, 1807-27] thought that there was no right of peer to carry an address or petition to the sovereign privately, see Pike, n 37 , pp 253-4. Campion (in 1929), n 31, p 40 'The claim of access to the royal person is not for the access of members as individuals...but for the house as a body headed by the speaker, and only for the purpose of presenting an address.' Munro, n 43, p 219 thought this privilege was not very important.

${ }^{244}$ May (in 1844), n 3, p 47. Ibid (2019), n 4, p 252 'The request is now little more than a formal courtesy...'. Campion (in 1929), n 31, p 40 'generally held to be made merely by courtesy.' Munro, n 43, p 219, thought this privilege was not very important.
} 
agreed to not bring their private armies to Parliament, if Edward II (1307-27) pardoned them for killing his favourite, Gaveston. Thus, this Act was designed to prevent private armies being brought to Parliament. It was not intended to prevent MP's from carrying private weapons (swords etc) in Parliament - which they continued to do up to the Restoration. There is (it seems) no caselaw and this Act was, likely, temporary legislation since it was not subsequently used in later times when private armies (or mobs) threatened Parliament. It is (exceedingly) unlikely a prosecution under this Act would ever be brought today because of the obscure wording of this Act and the subject matter being covered by the Treason Felony Act 1848. This crime is obsolete and the content of this Act is, now, governed by the Public Order Act 1936 (quasi-military institutions), the Treason Felony Act 1848, s 3 (intimidating Parliament) and legislation on firearms and offensive weapons. This legislation is considered in detail in an article. ${ }^{245}$ It should be abolished.

- Parliamentary and Other Pensions Act 1972. This Act was comprehensively amended by the Public Service Pensions Act 2013 and is spent. So too, are the Parliamentary and other Pensions and Salaries Act 1976, Parliamentary Pensions etc Act 1984 and the Parliamentary and other Pensions Act 1987.

- $\quad$ Parliament (Qualification of Women) Act 1918. S 1 (capacity of women to be members of Parliament). 'A woman shall not be disqualified by sex or marriage for being elected to or sitting or voting as a Member of the Commons House of Parliament.' It is suggested that provision for this is otiose - since women have now sat in Parliament for more than 100 years and such a confirmation is not required today. See also 21(b).

In conclusion, obsolete legislation should be abolished.

\section{ABOLISHING OBSOLETE PARLIAMENTARY PRACTICES}

There are some Parliamentary formalities which, it is suggested, are otiose in modern times:

\section{(a) Bill read Pro-Forma after Queen's Speech}

After Parliament has been summoned and opened (convened) - and the Queen's Speech has been read to both houses of Parliament - the HC and HL adjourn, as noted by May (in 1844):

When the speech has been delivered, either by $[\mathrm{HM}]$ in person, or by commission, the [HL] is adjourned during pleasure, and the commons separate for an hour or two, without any formal adjournment; and if any members desire to be sworn on that day, it is usual for the house to re-assemble before four o'clock. When the houses are resumed in the afternoon, the main business is for the lord chancellor in the lords, and the speaker in the [HC] to report [HM's] speech. In the former house the speech is read at length by the clerk, and in the latter by the speaker, who states that for greater accuracy he had obtained a copy.

But before this is done it is the practice in both houses to read some bill a first time pro-forma, in order to assert their right of deliberating without reference to the immediate causes of the summons. This practice in the Lords is enjoined by a standing order. In the Commons the same form is observed by ancient custom only. There is an entry on the Journal of the 22d March 1603 'That the first day of every sitting, in every Parliament, some one bill, and no more, receiveth a first reading for form 's sake.' And this practice has continued till the present time. By the lords' standing order it would appear necessary that this form should be observed immediately after the oaths have been taken; but in the Commons the bill is only required to be read before the report of the Queen's speech, and other business is constantly entered upon before the reading of the bill... 246

Today, the pro forma reading is purely formal and there is no substantive reason for it. ${ }^{247}$

In conclusion, the need to: (a) report (i.e. read) the Queen's speech; and (b) the practice of reading a pro-forma bill should be dispensed with.

(b) Address of Both Houses in reply to the Sovereign

\footnotetext{
${ }^{245}$ See GS McBain, Abolishing Obsolete Legislation on Crimes and Criminal Procedure (2010) Legal Studies, pp 19-23.

${ }^{246}$ May (in 1844), n 3, pp 143-4. Ibid, p 34. Hatsell (in 1785), n 23, vol 2, p 59 'I understand the custom of reading a bill immediately on the return from the $[\mathrm{HL}]$, to be no more than a claim of right of the $[\mathrm{HC}]$, that they are at liberty to proceed, in the first place, upon any matter which they think material, without being limited to give a preference to the subjects contained in the king's speech'. He also noted that this reading was for form's sake. Since the sovereign's speech [royal address] now reflects the will of the government, not the will of the sovereign, there is no logical reason to preserve this.

${ }^{247}$ May (in 2019), n 4, pp 180-1'It is the practice, in both houses, to read some bill first time formally, in order to assert their right of deliberating without reference to the immediate cause of summons. In the Lords this practice is governed by Standing Order no 75. In the Commons the same form is observed pursuant to ancient custom. The Select Vestries Bill is read in the Lords and the Outlawries Bill in the Commons. Debate is out of of order. In the Commons, the bill is recorded as having been read the first time and ordered to be read a second time, but no day is appointed for the second reading. In neither house is the bill ordered to be printed.' Ridges (in 1934), n 24 , p 47 'in each house an obsolete bill is read for the first time in order to mark the right of the two houses to initiate legislation independently of the king's speech.'
} 
After the Queen's speech, an Address of both houses to the sovereign was moved, as noted by May (in 1844):

When the royal speech has been read, an address in answer to it is moved in both houses. Two members in each house are selected by the administration for moving and seconding the address...The address is an answer, paragraph by paragraph, to the Queen's speech. Amendments may be made to any part of it, and when the question for an address, whether amended or not, has been agreed to, a select committee is appointed 'to prepare' or 'draw up' an address. When the report is received from this committee, amendments may still be made to the address before it is agreed to: and after it has been finally agreed to, it is ordered to be presented to [HM].

When the speech has been delivered by the Queen in person, the address is presented by the whole house; but when it has been read by the lords commissioners, the address of the upper house is presented 'by the lords with white staves'; [i.e. the royal household] and the address of the Commons by 'such members of the house as are of [HMs] most honourable privy council.' When the address is to be presented by the whole house, the 'lords with white staves' in the one house, and the privy councillors in the other, are ordered to know [HM's] pleasure when she will be attended by the address. Each house meets when it understood that this ceremony will take place, and after [HM's] pleasure has been reported, proceeds separately to the palace. ${ }^{248}$

Also, messages under the royal sign manual, usually, were acknowledged by an Address of both houses. ${ }^{249}$ Neither of these would seem necessary today. ${ }^{250}$ The reason why is that - at least since Victorian times - the opening address is read by the sovereign but does not reflect her views. ${ }^{251}$ Rather, it reflects (wholly) the government and the programme of legislation which it intends to effect. The ensuing debate reflects this. In short, the role of the sovereign has become purely formal and any address in reply ${ }^{252}$ is (really) otiose since such is not intended to comprise any discussion with the sovereign on the matter. The same applies to any message sent by the sovereign in respect of which a written reply by the Speaker(s) of the HC and the HL would seem sufficient. Otherwise, in both cases, Parliamentary time is wasted on communications that are purely formal. Would the sovereign object to modernising this procedure? Surely not.

In conclusion, the need for a formal Address in reply should be dispensed with in both cases.

\section{(c) Use of Parchment}

The journals of the HL (but not of the HC) ) $^{253}$ were, once, on parchment. However, as May noted (in 1844) the practice had long been discontinued. ${ }^{254}$ Today, Acts, in the case of their retention by Parliament, have a parchment (vellum) cover. However, there seems to be little good reason for retaining such a (costly) practice and it is suggested that parchment be dispensed with.

In conclusion, any requirement for any Acts to be on parchment should be dispensed with.

\section{(d) Written HL Protests}

May (in 1844) noted that:

In addition to the power of expressing assent or dissent by a vote, peers may record their opinion, and the grounds of it, by a 'protest', which is entered in the Journals, together with the names of all the peers who concur in it... When a protest has been drawn up, any peer may subscribe it without remark, if he assent to all the reasons assigned to it; or he may signify the particular reasons which have induced him to attach his signature. ${ }^{255}$

\footnotetext{
${ }^{248}$ May (in 1844), n 3, p 144.

${ }^{249} \mathrm{Ibid}, \mathrm{p} 264$ 'Messages under the royal sign manual are generally acknowledged by addresses in both houses, which are presented from one house by the 'lords with white staves', and from the other by privy councillors, in the same manner as addresses in answer to royal speeches, when Parliament has been opened by commission.'

${ }^{250}$ See May (2019), n 4, pp 181-2 (address in reply to Queen's speech), p 190 (address to communication under the royal sign manual).

${ }^{251}$ Keith, $\mathrm{n} 59, \mathrm{p} 75$ (writing in 1936) 'It is in fact the custom that the draft of the royal speech on the opening of Parliament should formally be approved in Council, thus placing the full responsibility on the Cabinet. The recognition of the responsibility of ministers is of ancient date.' For the inability of Queen Victoria to alter wording to the Opening Speech in 1881 (announcing an intention not to retain Kandahar, in southern Afghanistan), Ibid, 'At 4 pm the queen [Victoria] yielded to the plain warning that to disapprove was to eject the ministry, and that on the eve of the opening of Parliament was revolution.' Keith noted 'There is, of course, an absolute right on the part of the sovereign to suggest changes in wording, but plainly, as the speech is the ministerial manifesto of its active policy, it is impossible for the cabinet to go beyond narrow limits in permitting its emasculation.' This was said in 1936. Today, the sovereign's role is formal only.

${ }^{252}$ May (in 2019), n 4, p 183 'After the address has been agreed to, it is ordered to be presented to [HM]. In the case of an address of the [HL] it is usual for the presentation to be ordered to be made 'by the lords with white staves' (that is, the royal household); and in the case of the address of the [HC] by 'such members of the house and of [HM's] most honourable privy council, one of [HM's] household. [HM's] answer to the address of each house is now invariably of a formal character.' See also Ibid, p 193.

${ }^{253}$ See May (1844), n 3, p 158 ('does not appear to have been adopted by the Commons').

${ }^{254}$ Ibid, pp 158-9.

${ }^{255}$ Ibid, pp 221-2. For collections of protests (up to 1874), see WH Sweet \& LF Maxwell, A Legal Bibliography of he British Commonwealth of Nations (1955), vol 1, pp 144-5. See also Pike, n 37, pp 245-6.
} 
Such written protests are now rare in comparison with former times. Also, the HC does not have such a process. It is asserted the same is no longer required. Not least, since the proceedings of Parliament are now published and there is nothing to prevent a peer protesting in this fashion when speaking in a debate or via the way he (or she) votes.

In conclusion, written protests by peers in the HL should be abolished.

\section{(e) Petitions}

When the sovereign exercised executive power, the same was (often) petitioned as part of the political process and generally (e.g. in respect of miscarriages of justice). ${ }^{256}$ Petitions were also made to the HC and HL (by 1844, when May wrote, the HC was receiving more petitions than the HL). Because of the volume and singularity (i.e. the quixotic nature) of some of the petitions submitted, Parliament laid down some rules. It also required all public petitions to be referred to the 'Committee for Public Petitions'.

- Today, given that the role of the sovereign is a formal one - and to save time and expense - a Parliament Act should provide that petitions to: (a) the Crown (including the sovereign in person); (b) Parliament (including the HC and the HL distinctly); and (c) the government, should be addressed to - and handled by - the Petitions Committee in Parliament (established 2015). ${ }^{257}$

- $\quad$ Also, a Parliament Rule Book should set out, in modern form, simple rules re e-petitions ${ }^{258}$ and end hard copy (paper) petitions. ${ }^{259}$ All this will save time, expense and administration.

In conclusion, petitions should be handled by a Petitions Committee of Parliament, regardless of whether they are addressed to the Crown (including the sovereign), Parliament (including the HC or HL distinctly) or the government.

\section{(f) Creating new Privileges}

May (in 1844) noted:

Although either house may expound the law of Parliament, and vindicate its own privileges, it is agreed that no new privilege can be created. In 1704, the lords communicated a resolution to the commons at a conference: 'That neither house of Parliament have the power, by any vote or declaration, to create to themselves new privileges, not warranted by the known laws and customs of Parliament'; which was assented to by the Commons. ${ }^{260}$

It would seem appropriate to place this in a Parliament Act (obviously, a future Parliament could create, in an Act, a new Parliamentary privilege in any case).

In conclusion, Parliament should not be allowed to create any new privileges informally.

\section{CLARIFYING AND MODERNISING PARLIAMENTARY PROCEDURE}

The internal procedure of Parliament has grown up over the centuries in a very haphazard fashion. One, often, dictated by Parliamen's struggles with the Crown (and by the HC with the HL) as well as resulting from political events. Thus, it has become something which (not uncharitably) can be called an arcane mis-mash. One only truly understood by the cognoscenti - those who (often) had a vested interest to preserve their status, and private fiefdoms, within the structure of Parliament. This was at the expense of open, transparent democratic Parliamentary debate (though this is less so today). May (in 1844), more than 150 years ago, noted the complexity - indeed, the intelligibility - of much Parliamentary procedure. He stated (in respect of motions and questions):

Very few general rules have been entered on the Journals of either house; but the practice of Parliament has established certain forms of procedure, which numerous precedents rarely fail to make intelligible. ${ }^{261}$

Today, there is no need for this. Arcane and complicated rules do no service to democracy. They simply delay the good administration, and operation, of Parliament. Also, they are of no assistance to Commonwealth and other countries which would - otherwise - likely follow Westminster precedent (important in a world where a curtain of dictatorship appears to be descending once more across large swaths of it). Thus, a Parliament Act should require Rules of Parliament to be drawn up. This would not be complex. ${ }^{262}$ Such Rules of Parliament should include rules on the following:

\footnotetext{
${ }^{256}$ See also May (in 1844), n 3, ch 19. The Bill of Rights 1688, s 1(right to petition) states: 'That it is the right of the subjects to petition the king and all commitments and prosecutions for such petitioning are illegal.' This should be preserved in a Parliament Act.

${ }^{257}$ See also May (2019), n 4, p 540 'In May 2007, the Procedure Committee expessed the view that 'Parliament should be the primary recipient of petitions from the public.'

${ }^{258}$ For the modern position on petitions see May (in 2019), $\mathrm{n} 4$, ch 24.

${ }^{259}$ As May (2019) also notes, n 4, p 539 'In the [HL], members can present public (paper) petitions. This procedure is rarely used.'

${ }^{260}$ May (in 1844), n 3, pp 48-9. See also May (2019), n 4, p 323, fn 2.

${ }^{261}$ Ibid, p 166.

${ }^{262}$ A (masterly) analysis of Parliamentary procedure was provided by May (in 1844) in matters in which he had long experience. This has been updated throughout subsequent editions of his text.
} 
- $\quad$ Sittings (of the HC and the HL and in Westminster Hall);

- Order of Business; ${ }^{263}$

- Motions; ${ }^{264}$

- Questions; ${ }^{265}$

- Decisions; ${ }^{266}$

- Debate (including manner of speaking, time and length of speeches, content of speeches, behaviour and enforcement of order by the chair);267

- Divisions, ${ }^{268}$

- $\quad$ Passage of bills (see also 22);269

- Passage of statutory instruments (i.e. delegated legislation), ${ }^{270}$

- Protests ${ }^{271}$ (see 19(d))

- Personal Interests; $;^{272}$

- $\quad$ Committees of the whole House, ${ }^{273}$

- $\quad$ Select Committees; ${ }^{274}$

- General and Grand Committees; ${ }^{275}$

- Witnesses; ${ }^{276}$

- Communications between the HL and the HC, ,277 $^{-}$

- Communications between the Crown and Parliament (including Addresses by Parliament). ${ }^{278}$

- Petitions, ${ }^{279}$ (see 19(e)).

- Contempt of Parliament; ${ }^{280}$

- $\quad$ Other matters.

In respect of the above, it may be noted that the first edition of May (in 1844) was a text of 460 pages. The current edition (the $25^{\text {th }}$, published in 2019) comprises 1181 (closely typed) pages. While this is, doubtless, good for the publisher (the text is very expensive) - and for converting the law into one only for the cognoscenti - there is no reason for rules and practices of Parliament to be in such a vague and fragmentary state. They could, easily, be converted into simple rules, using modern terminology. ${ }^{281}$ As well as these Rules of Parliament, there should be (and, indeed is) a Code of Conduct. This should set out - in a user friendly and modern manner - a comprehensive code of behaviour for MPs and peers. In conclusion, it would (manifestly) be of benefit to MPs, peers and everyone else if there was an annual (softback) publication (also online) containing the following:

\footnotetext{
${ }^{263}$ For the modern position see May (2019), n 4, chs $17 \& 18$.

${ }^{264}$ See May (in 1844), n 3, pp 166-71. For the modern position see May (2019), n 4, ch 20.

${ }^{265} \mathrm{Ibid}, \mathrm{pp} 171-91$. For the modern position see May (2019), n 4, ch 20.

${ }^{266}$ For the modern position see May (2019), n 4, ch 20.

${ }^{267}$ Ibid, pp 191-211. For the modern position see May (2019), n 4, ch 21.

${ }^{268}$ Ibid, pp 212-221.

${ }^{269}$ For public bills today, see May (in 2019), n 4, chs 26- 30. For private bills (now rare), see Ibid, chs 42-6.

${ }^{270} \mathrm{Ibid}$, ch 31 .

${ }^{271}$ Ibid, pp 221-2.

${ }^{272}$ Ibid, pp 222-3. See also May (2019), n 4, pp 81-90.

${ }^{273} \mathrm{Ibid}$, pp 224-9. This will not apply if the HL is abolished. For joint committees today, see May (in 2019), ch 41.

${ }^{274}$ Ibid, pp 230-238. For select committees today, see May (in 2019), n 4, ch 38 (HC), ch 40 (HL).

${ }^{275}$ For general committees of the HC and grand commmittes, see May (in 2019), n 4, ch 39 (HC).

${ }^{276}$ Ibid, pp 238-48.

${ }^{277}$ Ibid, pp 249-58. This will not apply if the HL is abolished.

${ }^{278}$ Ibid, pp 259-68. Addresses by Parliament may be joint or single (the former are not required if the HL is abolished). Ibid, pp 266-8.

${ }^{279}$ Ibid, pp 300-8.

${ }^{280}$ For the modern position see May (2019), n 4, ch 15.

${ }^{281}$ It may also be noted that - if the HL were abolished - the size of this text would be nearly halved. And, if the procedure for private Acts was simplified, such would excise another 200 pages or so.
} 
- A Parliament Act (and other relevant legislation); ${ }^{282}$

- Rules of Parliament;

- A Code of Conduct of Parliament (including a behaviour code). ${ }^{283}$

Then, everyone would know what Parliament is about - including those who work there! One would suggest (vested interests aside) there is nothing difficult about this.

In conclusion, the practices and procedure of Parliament should be set out in clear Rules of Parliament.

\section{CONSOLIDATING REMAINING PARLIAMENTARY LEGISLATION}

Apart from obsolete Parliamentary legislation, remaining legislation on Parliament which is still extant is of an administrative nature and it has been subject to (very) little contention (i.e. caselaw) or analysis. What is needed is to modernise the language which is (often) archaic. Such legislation may be gathered under the following headings:

- Title of Parliament

- Disqualification from Parliament

- Recall of MP's

- Deputy Speaker

- Parliamentary Clerks

- Parliamentary Commissioner

- Parliamentary Constituencies

- House of Commons Commission

- Parliamentary Corporate Bodies

- Parliamentary Joint Departments

- Acts of Parliament

- Laying documents before Parliament

- Parliamentary Papers

- Parliamentary Returns

- Parliamentary Costs

- Parliamentary Standards

- Parliamentary Oaths

- Parliamentary Pensions

- Courts

- Chequers and Chevening Estates

- $\quad$ Statute of Westminster 1931

As to this legislation:

\section{(a) Title of Parliament}

The Royal and Parliamentary Titles Act 1927, s 2 (alteration of the style of Parliament), states:

(1) Parliament shall hereafter be known as and styled the Parliament of the [UK] of [GB] and Northern Ireland;

(2) In every public document issued after the passing of this Act the expression '[UK]' shall, unless the context otherwise requires, mean $[\mathrm{GB}]$ and Northern Ireland.

Also, the Union with Scotland Act 1706, art 3 states 'That the [UK] of [GB] be represented by one and the same Parliament to be styled The Parliament of Great Britain.' The Union with England Act 1707, art 3 contains a similar provision. Both should be replicated in a Parliament Act.

In conclusion, this material should be consolidated into a Parliament Act. It would seem useful, for the purpose of legislation, to be able to shorten Parliament's title to the 'UK Parliament', where required.

\footnotetext{
${ }^{282}$ All legislation relating to elections should be gathered into one Parliamentary Elections Act.

${ }^{283}$ The Committee on Standards would have control over the Code (and its updating). See also May (2019), n 4, pp 78-80. The Code should be a combined Code (that is, also incorporate the Code of Behaviour) in order to make it more user friendly.
} 


\section{(b) Disqualification from Parliament}

Extant legislation provides for the removal of any disqualification of women and clergy being MP's. It also disqualifies certain people from sitting in the $\mathrm{HC}$ and the HL. As to these:

\section{(i) $\underline{\text { Women }}$}

Women were disqualified from being represented in Parliament until the Parliament (Qualification of Women) Act 1918. Section 1 (capacity of women to be members of Parliament) states:

A woman shall not be disqualified by sex or marriage for being elected to or sitting or voting as a member of the Commons House of Parliament.

Since women have now sat in Parliament for more than 100 years, this statutory provision is otiose. There is also the Lords Spiritual (Women) Act 2015, s 1 (see 2), which, if the HL were abolished, would not be required in a Parliament Act.

This Act does not need to be placed in a Parliament Act, if the grounds for disqualification are listed in the same.

\section{(ii) $\underline{\text { Clerics }}$}

These were prevented from sitting in the HC. ${ }^{284}$ However, the House of Commons (Removal of Clergy Disqualification Act) 2001, s 1 (removal of disqualification of clergy) states:

(1) A person is not disqualified from being or being elected as a member of the [HC] merely because he has been ordained or is a minister of any religious denomination.

(2) But a person is disqualified from being or being elected as a member of the [HC] if he is a Lord Spiritual.

This Act does not need to be placed in a Parliament Act, if the grounds for disqualification are listed in the same.

\section{(iii) Hereditary Peers}

The House of Lords Act 1999, s 3 (removal of disqualifications in relation to the HC) states:

(1) The holder of a hereditary peerage shall not be disqualified by virtue of that peerage for - (a) voting at elections to the $[\mathrm{HC}]$, or (b) being, or being elected as, a member of that house.

(2) $[\mathrm{ss}](1)$ shall not apply in relation to anyone excepted from $[\mathrm{s}] 1$ by virtue of $[\mathrm{s}] 2 .{ }^{285}$

Further, the House of Lords Reform Act 2014 and the House of Lords (Expulsion and Suspension) Act 2015 provide for the removal of peers for non- attendance, the commission of a serious offence, etc. Disqualification from the HL also applies in respect of: (a) aliens (see vii below); (b) persons under 21; (c) bankruptcy; (d) treason; (e) holding a disqualifying judicial office. ${ }^{286}$

These Acts should be placed in a Parliament Act (assuming the HL is not abolished).

\section{(iv) $\underline{\text { House of Commons (Disqualification) Act } 1801}$}

This contains the following sections:

- $\quad \mathbf{S} 1$ (all persons disabled from sitting in British Parliaments shall be disabled from sitting in the United Parliament as members for $[G B]$ ). From and after the passing of this Act, all persons disabled from or incapable of being elected, or sitting and voting in the [HC] of any Parliament of [GB], shall be disabled from and be incapable of being elected, or sitting and voting in the [HC] of any Parliament of the [UK], as knights, citizens, or burgesses, for any county, city, borough, cinque port, town, or place, in this part of the [UK] called [GB].

- $\quad \mathbf{S} 2$ (all persons disabled from sitting in Irish Parliaments shall be disabled from sitting for Ireland). And from and after the passing of this Act, all persons disabled from or incapable of being elected, or sitting and voting in the $[\mathrm{HC}]$ of any Parliament of Ireland, shall be disabled from and be incapable of being elected, or sitting and voting in the $[\mathrm{HC}]$ of any Parliament of the [UK], as knights, citizens, or burgesses, for any county, city, borough, town, or place, in Ireland.

- $\quad \mathbf{S} 3$ (persons disabled by British statutes shall not hereby be enabled to sit for Ireland, nor e contra). Provided nevertheless, that nothing in this Act shall be construed to enable persons, heretofore disabled by any Act of the Parliament of [GB], from sitting and voting in the [HC] of [GB], to sit or vote in the [HC] of the said Parliament of the said [UK] as knights, citizens, or burgesses for any county, city, borough, town, or place in Ireland; nor to enable persons, heretofore disabled by any Acts of the Parliament of Ireland from sitting and

\footnotetext{
${ }^{284}$ Clergy were not, originally, ineligible, see May (in 1844), n 3, pp 27-8. Also, Hatsell (in 1785), n 23, vol 2, pp 7-11.

${ }^{285}$ i.e. to the 92 hereditary peers entitled to sit in the HL (thus, a person cannot sit in both the HC and the HL at the same time).

${ }^{286}$ See generally May (2019), n 4, pp 41-4.
} 
voting in the $[\mathrm{HC}]$ of Ireland, to sit or vote in the [HC] of the Parliament of the said [UK], as knights, citizens, or burgesses, for any county, city, borough, cinque port, town, or place, in this part of the [UK] called [GB]

This Act would appear to be spent since it pre-dates the Republic of Ireland and devolution. If not, it should be placed in a Parliament Act, to the extent still of worth. ${ }^{287}$

\section{(v) Succession to the Crown Act 1707}

This Act, s 29 states:

And every person disabled to be elected or to sit or vote in the [HC] of any Parliament of England shall be disabled to be elected or to sit or vote in the [HC] of any Parliament of [GB].

This reference is spent and no longer appropriate since the parliament, today, is the UK Parliament (this Act was before the Irish Act of Union 1800. Therefore, it was only considering the position in respect of a united Parliament of England and Scotland). Further, it is not required if a Parliament Act specifies, with precision, who may sit in the UK Parliament.

This Act need not be placed in a Parliament Act.

\section{(vi) House of Commons Disqualification Act 1975}

This Act, $\mathrm{s} 1$ (disqualification of holders of certain offices and places) states:

(1) Subject to the provisions of this Act, a person is disqualified for membership of the [HC] who for the time being

(za) is a Lord Spiritual;

(a) holds any of the judicial offices specified in [Sch 1, pt 1];288

(b) is employed in the civil service of the Crown, whether in an established capacity or not, and whether for the whole or part of his time;

(c) is a member of any of the regular armed forces of the Crown;

(d) is a member of any police force maintained by a local policing body or a police authority;

(e) is a member of the legislature of any country or territory outside the Commonwealth (other than Ireland);

or

(f) holds any office described in [Sch 1, pts $2 \& 3{ }^{289}$

(2) A person who for the time being holds any office described in [Sch 1, pt 4] is disqualified for membership of the $[\mathrm{HC}]$ for any constituency specified in relation to that office in [Pt 4, column 2]. ${ }^{290}$

(4) Except as provided by this Act, a person shall not be disqualified for membership of the [HC] by reason of his holding an office or place of profit under the Crown or any other office or place; and a person shall not be disqualified for appointment to or for holding any office or place by reason of his being a member of that house.

S 2 (ministerial offices) states:

\footnotetext{
${ }^{287}$ This Act was enacted subsequent to the Union with Ireland Act 1800 (extant). This Act can only apply now to Northern Ireland ('NI') and it should refer to the NI Assembly.

${ }^{288}$ This refers to the following offices: judge of the supreme court, judge of the high court of justice or court of appeal, judge of the court of session, or temporary judge in Scotland, judge of the high court of justice or court of appeal in NI, judge of the court martial appeal court, chairman of the Scottish land court, circuit judge, sheriff principal, sheriff, summary sheriff, temporary sheriff principal, part-time sheriff or part-time summary sheriff in Scotland, county court judge or deputy county court judge in NI, district judge (magistrates' courts) (but not deputy district judge (magistrates' courts)), district judge (magistrates' courts), or deputy district judge (magistrates' courts), in NI, chief or other child support commissioner for NI or deputy child support commissioner for NI, chief or other social security commissioner (not including a deputy commissioner), chief or other social security commissioner for NI or deputy social security commissioner for NI.

${ }^{289}$ This refers to the following offices: prime minister and first lord of the treasury, lord president of the council, lord privy seal, chancellor of the duchy of lancaster, paymaster general, secretary of state, chancellor of the exchequer,president of the board of trade, minister of state, chief secretary to the treasury, minister in charge of a public department of [HM's] government in the [UK] (if not within the other provisions of this schedule), attorney general, solicitor general, advocate general for Scotland, parliamentary secretary to the treasury, financial secretary to the treasury, parliamentary secretary in a government department other than the treasury, or not in a department, junior lord of the treasury, treasurer of [HM's] household, comptroller of [HM's] household, vice-chamberlain of [HM's] household, assistant government whip.

${ }^{290}$ Ss (3) states: In this section- "civil service of the Crown" includes the civil service of NI, [HM's] diplomatic service and [HM's] overseas civil service; "police authority" means any police authority within the meaning of the Police Act 1996, the Scottish police authority, or the NI policing board; and "member" in relation to a police force means a person employed as a full-time constable; "regular armed forces of the Crown" means the royal navy, the royal marines, the regular army (as defined by [s] 374 of the Armed Forces Act 2006) or the royal air force.
} 
(1) Not more than [95] persons being the holders of offices specified in [sch 2] (in this [s] referred to as Ministerial offices) shall be entitled to sit and vote in the $[\mathrm{HC}]$ at any one time.

(2) If at any time the number of members of the $[\mathrm{HC}]$ who are holders of ministerial offices exceeds the number entitled to sit and vote in that house under [ss 1], none except any who were both members of that house and holders of ministerial offices before the excess occurred shall sit or vote therein until the number has been reduced, by death, resignation or otherwise, to the number entitled to sit and vote as aforesaid.

(3) A person holding a ministerial office is not disqualified by this Act by reason of any office held by him ex officio as the holder of that ministerial office.

Further sections deal with s 3 (reserve and auxiliary forces); 4 (stewardship of Chiltern Hundreds), 5 (power to amend sch 1), 6 (effects of disqualification and provision for relief), 7 (jurisdiction of the privy council as to disqualification), ${ }^{291} 8$ (relaxation of obligation to accept office), 9 (interpretation).

In the case of s 4 above, the Chiltern Hundreds is a device (a fiction) that an MP who resigns (retires) is taking up a paid Crown office and therefore can no longer sit in the HC. ${ }^{292}$ This is employed to avoid a Parliamentary principle (not a law) ${ }^{293}$ that an MP cannot relinquish (resign, retire) his (or her) seat unilaterally. However, such is outdated today and this device is a circumlocution which achieves no more than if resignation were permitted. Thus, a Parliament Act should make direct provision for an MP being able to resign/retire.

This Act should be placed in a Parliament Act.

\section{(vii) Act of Settlement 1700}

This Act, s 3 states:

no person born out of the kingdoms of England Scotland or Ireland or the dominions thereunto belonging although he be made a denizen (except such as are born of English parents) shall be capable to be of the privy council or a member of either House of Parliament or to enjoy any office or place of trust either civil or military or to have any grant of lands, tenements or hereditaments from the Crown to himself or to any other or others in trust for him. ${ }^{294}$ (wording in italics is spent)

As May (2019) notes, s 3 does not apply to:

- Commonwealth citizens; or

- $\quad$ citizens of the Republic of Ireland. The former refers to: (a) a British citizen; (b) a British overseas territories citizen, (c) a British National (Overseas); (d) a British Overseas citizen; (e) a British subject; (f) a citizen of a Commonwealth country mentioned in sch 3 to the Act. ${ }^{295}$

\footnotetext{
${ }^{291}$ The High Court should now deal with such matters, see GS McBain, Modernising the English Court System (2013) Journal of Politics and Law, vol 6, no 3, pp 18-28. May (2019) notes, n 4, pp 39-40, that 'no such application has been made [to the Judicial Committee of the Privy Council] and no rules for such a procedure have yet been made.' There is also an alternative method (May, $\mathrm{p} 40$ ) which would seem adequate. ${ }^{292}$ Campion, n 31, p 39 'by a useful fiction, originating about 1750 (Hatsell), he [an MP] accepts an office which is nominally of profit, and thereby vacates his seat. The offices selected since 1750: are; (1) steward or bailiff of [HM's] three Chiltern hundreds of Stoke, Desborough and Burnham, and (2) steward of the manor of Northstead. They count as offices of profit and vacate a seat because, though merely nominal, the warrants contain grants of 'wages, fees and allowances.' However, this fiction may have an historical basis since the Act of Settlement 1700 provided that 'so soon as the house of Hanover shall come to the throne, no person who has an office or place of profit under the king, or receives a pension from the Crown, shall be capable of serving as a member of the [HC]'. Maitland, n 43, p 292 who stated: 'This momentous clause never came into force: it was repealed in 1705 before the house of Hanover came to the thone.'

${ }^{293}$ May (2019), n 4, p 37 refers to 'parliamentary law'; however there is none (in other words, the courts have never accepted that such exists as a distinct category of law). It also seems clear that the prohibition derived not from any Crown prerogative to prohibit a person refusing/retiring from a Crown office without Crown permission (a contempt of the sovereign). Rather, it was a matter of Parliamentary practice. See Hatsell (in 1785), n 23, vol 2, p 56 (the earliest statement he refers to on relinquishment is quite recent (in Parliamentary terms) 'On the [2 March 1623] it is agreed, that a man, after he is duly chosen [as an MP], cannot relinquish).'

${ }^{294}$ The wording in italics has been considered in the context of a Crown Act, see McBain, n 1, p 55 which proposed that reference should be made (as to whether a person could be a privy councillor or not) not by reference to the place of birth of the same but whether they were are a British subject or naturalised.

${ }^{295}$ May (2019), n 4, pp 29-30.
} 
Section 3 has been modified. ${ }^{296}$ As it is, s 3 should be placed in a Parliament Act. However, consideration should be given to removing some of these categories. Also, to impose a residence requirement. ${ }^{297}$ For example, removing citizens of the Republic of Ireland and Commonwealth countries - since their inclusion results from historical events and these countries are no longer dominions; further, they now have their own Parliaments. Thus, possibly, MPs should be restricted to British citizens who are permanently resident in the UK.

There are other pieces of legislation which relate to disqualification from the House of Commons, viz.

\section{(viii) Other Pieces of Legislation}

- Electoral Administration Act 2006. As May (2019) notes, persons under 18 are disqualified from election to the $\mathrm{HC}$ by the Electoral Administration Act 2006, the section is s $17 .{ }^{298}$

- Insolvency Act 1986. The Insolvency Act 1986, ss 426(a) and 427 provide that a person in respect of whom a bankruptcy restriction order (or a debt relief restrictions order) has effect, is disqualified from membership of the HC. ${ }^{299}$

- $\quad$ Forfeiture Act 1870. This provides that persons convicted of treason are disqualified from sitting (or voting) in either the $\mathrm{HC}$ or $\mathrm{HL}$ - until the expiry of their sentence or receipt of a pardon. ${ }^{300}$

- $\quad$ Representation of the People Act 1981. This provides that:

- $\quad$ any person who, in a country and for any offence, is sentenced or ordered to be imprisoned or detained indefinitely (or for more than [1] year), shall be disqualified while they are detained anywhere in the British Islands or the Republic of Ireland (or unlawfully at large when they would, otherwise, be detained),

- $\quad$ and the election, or nomination, of such a person shall be void, and

- the seat of a member who becomes so disqualified shall be vacated. ${ }^{301}$

- $\quad$ Representation of the People Act 1983, s 173. May (2019) notes that the statutory penalties inflicted for corrupt or illegal practices at elections under this Act may have the effect of disqualification from membership of the HC. ${ }^{302}$ It is assert that such should apply. And, that s 66 (election offences) should also apply. ${ }^{303}$

- $\quad$ Recall Act 2015. Under this Act, s 15, an MP sentenced to imprisonment (including cases where the sentence is suspended) and who is not otherwise disqualified is subject to a recall petition once the appeal period has expired. If the petition reaches the required threshold, the seat of that MP is vacated. An MP whose seat has been vacated as result of the recall process is not disqualified from standing in a subsequent by-election. ${ }^{304}$

In conclusion, these Acts should be consolidated into a Parliament Act. However, they should be set out in simpler form so that it is easier to determine the grounds of disqualification.

\section{(c) Recall of MPs}

The Recall of MPs Act 2015 provides for a recall petition in certain circumstances relating to disciplinary or criminal offences committed by an MP. The Act has the following sections:

\footnotetext{
${ }^{296}$ Consitutional Reform and Governance Act 2010, s 47 (s 3 of the Act of Settlement) (1) For the avoidance of doubt, the repeal in [s] 18(7) of the Electoral Administration Act 2006 of the entry in [sch] 7 to the British Nationality Act 1981 (entry which modified certain disqualifications imposed by section 3 of the Act of Settlement) applied only so far as the modification made by that entry related to - (a) membership of the [HC] or (b) anything from which a person is disqualified by virtue of a disqualification from membership of that house. (2)[s] 3 of the Act of Settlement has effect accordingly, and has done so since the coming into force of [s] 18 of the Electoral Administration Act 2006. See also May (in 1844), n 3, p 26.

${ }^{297}$ May (2019), n 4, pp 29-30 'A person who is non domiciled for tax purposes may stand for election to the house, but once elected will be treated as domiciled'. It refers to the Constitutional Reform and Governance Act 2010, s 41.

${ }^{298}$ Ibid, p 30

${ }^{299}$ Ibid, p 31.

300 Ibid.

${ }^{301}$ Ibid, pp 31-2.

${ }^{302} \mathrm{Ibid}$, p 32 'Following investigation by an election court a candidate at a parliamentary election who is reported to be personally guilty of a corrupt or illegal practice, is incapable from the date of the report of being elected to or sitting in the [HC] for any constituency for [5] years (in the case of a corrupt practice) or three years (in the case of an ilegal one). If a candidate who has been found guilty of corrupt or illegal practices (whether personally or through agents) the election is void and the seat vacated.

303 These relate to personation etc.

${ }^{304}$ May (2019), n 4, p 32.
} 
Recall Act 2015. S 1 (how an MP becomes subject to a recall petition process), 2 (the first and third recall conditions - further provision), 3 (the first and third recall conditions - expiry of appeal period), 4 (the first and third conditions - courts to notify the speaker), 5 (Speaker's notice that first, second or third recall conditions have been met), 6 (petition officers), 7 (where and from when the recall petition may be signed), 8 (notice of petition to be sent to registered electors), 9 (recall petition to be made available for signing), 10 (persons entitled to sign a recall petition), 11 (how entitlement to sign a recall petition is to be exercised), 12 (double signing), 13 (early termination of recall petition process), 14 (determination whether recall petitions successful), 15 (effect of successful petition), 16 (expenses, donations and reporting), 17 (loans), 18 (power to make further provision about conduct of a recall petition etc), 19 (performance of the Speaker's functions by others), 21 (regulations).

\section{(d) Deputy Speaker}

The Deputy Speaker Act 1855 has sections which deal with the appointment of a deputy speaker in the HC in the absence of the speaker, $v i z:^{305}$

- S 1. (Acts done, \&c. by Deputy Speaker during absence of Speaker valid). If at any time during a session of Parliament the Speaker shall be temporarily absent from the house, and a Deputy Speaker ['DS'] shall thereupon perform the duties and exercise the authority of Speaker, pursuant to the standing orders or other order or resolution of that house, every act done and proceeding taken in or by the house pursuant to any statute shall be as valid and effectual as if the Speaker himself were in the chair; and every act done, and warrant, order, certificate, notice, or other document issued, signed, or published, in relation to any proceedings of the [HC], by such [DS], shall have the same effect and validity as if the same had been done, issued, signed, or published by the Speaker for the time being.

- S 2. (Deputy Speaker not to appoint to any Office). Provided, that such [DS] shall not have power to appoint to any office, except for such time as he shall continue to be [DS].

- S 3. (nothing herein to affect election of Speaker, \&c). Provided also, that nothing herein contained shall affect the election of a Speaker, or the forms thereof, or any prerogative of [HM] concerned therein, ${ }^{306}$ or otherwise relating to the office of Speaker.

Further, the Recess Election Act 1975, s 4 (appointment of members to exercise speaker's powers) states:

(1) It shall be the duty of the speaker, within a convenient time after taking office, by instrument in writing under his hand and seal, to appoint not more than [7] nor less than [3] members of the [HC] to exercise the powers given to the speaker by this Act at any time when there is no speaker or the speaker is out of the [UK]; and if the number of persons appointed is reduced to less than [3], he may appoint one or more further members. (2) An appointment shall remain in force until the dissolution of the Parliament in which it is made. (3) An appointment shall be entered in the journals of the $[\mathrm{HC}]$ and be published once in the London Gazette, and the instrument of appointment shall be preserved by the Clerk of the [HC], and a duplicate filed in the office of the Clerk of the Crown in Chancery. (4) The powers of the speaker may be exercised by any one of the members appointed under this section, but when notice of the issue of a warrant is brought to the publisher of the Gazette and is signed by a member so appointed, the publisher shall give a receipt for it, specifying the day and hour when it was received, and if more than one notice is brought to him relevant to the same election, he shall insert in the Gazette only the notice first received. ${ }^{307}$

In conclusion, these Acts should be consolidated into a Parliament Act (ss 2 and 3 of the Act of 1855 are not required).

\section{(e) Parliamentary Clerks}

The Clerk of the Parliaments Act 1824 has sections which make provision as to the appointment of Parliamentary clerks in the $\mathrm{HL}:{ }^{308}$

- $\quad \mathbf{S} 2$ (Clerk of the Parliaments to be appointed by [HM] and to execute duties in person). The clerk of the Parliaments shall be appointed by [HM], but such clerk of the Parliaments so appointed shall also execute the duties of the said office in person, and shall be removable by [HM], upon an address of the [HL] to [HM] for that purpose.

- $\quad \mathbf{S} \mathbf{3}$ (appointment of other clerks officiating at the table). The nomination and appointment of the clerk assistant and other clerks officiating at the table of the [HL] (except the clerk of the Parliaments as aforesaid) shall be vested in

\footnotetext{
${ }^{305}$ Ibid, pp 62-3, 178. Also, the House of Commons (Administration) Act 1978, sch 2, para 2.

${ }^{306}$ This reflects the Crown prerogative to approve the speaker, see 3(a).

${ }^{307}$ See also May (2019), n 4, p 23.

${ }^{308}$ May (in 1844) noted, n 3, p 156: 'The chief officers of the upper house [i.e. the HL] are the Clerk of the Parliaments (whose office is executed by the first and second clerks assistant), the gentleman and yeoman usher of the black rod, and the serjeant-at-arms. The clerks assistant and reading clerk attend at the table, and take minutes of all the proceedings, orders, and judgments of the house; these are published daily as the 'Minutes of the Proceedings', and they are printed, in a corrected and enlarged form, as the Lords' Journals, after being examined 'by the sub-committees for privileges and perusal of the Journal Book.'
} 
and exercised by the Speaker of the [HL], but subject always to the approbation of the said [HL], on such appointments being duly notified to the house; and such officers, when so appointed and approved, shall be removable only by order of the said [HL].

- $\quad \mathbf{S} \mathbf{8}$ (other clerks to be appointed by clerk assistant during existence of present letters patent). All the other clerks, except as aforesaid, belonging to the said office of Clerk of the Parliaments; (that is to say), the clerk of the journals, copying clerk, clerk of the engrossments, clerk of the inrolments, and the writing clerks under them, shall be nominated and appointed, and removable at pleasure, by the Clerk of the Parliaments for the time being executing in person the duties of the said office, according to the provisions herein-before contained.

Today, the Clerk of the Parliaments is responsible for the services provided in respect of the administration of the HL. ${ }^{309} \mathrm{He}$ (she) is appointed by the Crown (by letters patent) on the advice of the leader of the HL, after consulting the members of the HL. For its part, the House of Commons Offices Act 1856, s 1(appointment of clerk assistant confirmed and future clerks assistant to be appointed by [HM]) states:

The clerk assistant and second clerk assistant of the [HC] respectively shall be appointed by [HM], by warrant under her royal sign manual; and every clerk assistant and second clerk assistant shall be removable only by [HM], upon an address of the $[\mathrm{HC}]$ to $[\mathrm{HM}]$ for that purpose. ${ }^{310}$

May (2019) states:

The Clerk of the Parliaments is appointed by the Crown by letters patent under the great seal. Duties must be exercised in person, and the Clerk of Parliaments can be removed from office only by the sovereign upon an address of the [HL] for that purpose... The Clerk of the Parliaments employs all the staff in the administrative departments of the house. Clerks are appointed by and removable by the Clerk of the Parliaments. ${ }^{311}$ Also, the clerk assistant and reading clerk are appointed by the Lord Speaker, subject to the approbation of the house on their appointments being notified, and, when appointed, they cannot be suspended or removed from their offices without an order of the house....In performing their duties at the table of the house, the clerk of the Parliaments, clerk assistant and the reading clerk are assisted by other senior clerks who sit at the table according to a rota. ${ }^{312}$

The Clerk of the $[\mathrm{HC}]$ is the chief permanent officer of the $[\mathrm{HC}]$ and head of the House of Commons Service. The clerk is appointed by the Crown, by letters patent, in which they are styled 'Under Clerk of the Parliaments...to attend upon the Commons ${ }^{313} \ldots$ The clerk assistant is appointed by the Crown, under the sign manual, on the recommendation of the Speaker, and is removable only upon an address of the [HC]. ${ }^{314}$

If the HL were to be abolished, legislation relating to HL clerks is no longer required. In any case, the prerogative of the Crown to appoint Parliamentary clerks is no longer appropriate, being interference in the government of Parliament. Thus, such appointments (and any dismissal) should be made by the House of Commons Commission (see (h)) and by the Clerk of the Parliaments of HL, in respect of any HL clerk. The only exceptions should be the Clerk of the HC (the under clerk) and the Clerk of the Parliaments.

In conclusion, these Acts should be consolidated into a Parliament Act.

\section{(f) Parliamentary Commissioner ('PCA')}

Legislation which regulates the PCA (or Ombudsman) is as follows: ${ }^{315}$

- $\quad$ Parliamentary Commissioner Act 1967. This contains the following, s 1 (appointment and tenure of office); 2 (salary and pension); 3 (administrative provisions); 3A (appointment of acting c-er); 4 (department etc subject to investigation); 5 (matters subject to investigation); 6 (complaints); 7 (procedure in respect of investigations); 8 (evidence); 9 (obstruction and contempt); 10 (reports by PC); 11 (provision for secrecy of information); 11A (consultations between PC c-er and other c-ers or ombudsmen); 11ZAA (collaborative working between PC and

\footnotetext{
${ }^{309}$ May (2019), n 4, p 123 'The Clerk of the Parliaments employs all the staff in the administrative departments of the house.'

${ }^{310}$ May (in 1844), n 3, p 157, noted: 'The chief officers of the [HC] are, the clerk of the house, the first and second clerks assistant, and the sarjeant at arms. The clerk of the house is appointed by the Crown for life, by letters patent, in which he is styled under clerk of the Parliaments, to attend upon the Commons. The clerks assistant are appointed by him, and sit at the table of the house, on his left hand.' The first clerk assistant appears to have been appointed in 1640 at the request of the clerk of the $\mathrm{HC}$ (who is also called the 'Clerk of the Commons house of Parliament' or the 'Under Clerk of the Parliaments'). Thus, the nomination lay with the same and royal appointment was just a formality. See Hatsell (in 1785), n 23, pp 180-91. As to clerk of the HC, the first clerk seems to have been Seymour appointed in reign of Edward VI (154753), Ibid, p 185.

${ }^{311}$ May (2019), n 4, p 123.

312 Ibid, p 124.

${ }^{313}$ Ibid, pp 112-3.

${ }^{314}$ Ibid, p 114.

${ }^{315}$ Ibid, pp 129-30.
} 
other c-ers); 11AA (disclosure of information by PC to Information c-er); 11B (criminal injuries compensation scheme); 11C (victims of overseas terrorism compensation scheme); 12 (interpretation); 13 (application to NI). This Act was amended by the Parliamentary Commissioner (Consular Complaints) Act 1981, the Parliamentary Health Service Commissioners Act 1987 and the Parliamentary Commissioner Act 1994.

In conclusion, these Acts should be consolidated into a Parliament Act.

\section{(g) Parliamentary Constituencies}

Two pieces of legislation which principally regulate Parliamentary Constituencies comprise: ${ }^{316}$

- $\quad$ Parliamentary Constituencies Act 1986. This contains the following s 1 (Parliamentary constituencies); 2 (Boundary Commissions); 3 (reports of the Commissions); 4 (Orders in Council); 5 (publicity and consultation).

- Parliamentary Voting and Constituencies Act 2011. This contains the following, s 1 (referendum on the alternative vote system); 2 (entitlement to vote in the referendum); 3 (conduct of the referendum); 4 (combination of polls); 5 (press comment etc); 6 (control of loans); 7 (interpretation); 8 (commencement or repeal of amending provisions); 10 (boundary commission reports etc), 11 (number and distribution of seats), 12 (boundary commission proposals); 13 (National Assembly for Wales); 14 (review of reduction in number of constituencies); 15 (orders), 17 (financial provisions); 18 (extent).

In conclusion, these Acts should be consolidated into a Parliament Act.

\section{(h) House of Commons Commission}

The legislation which regulates the above is as follows:

- $\quad$ House of Commons (Administration) Act 1978. This contains the following, s 1 (House of Commons Commission); 2 (functions); 3 (financial provisions); 4 (house departments). ${ }^{317}$

The HC Commission is the overall supervisory body of the administration of the HC. Established in 1978, it prepares (and lays before the $\mathrm{HC}$ ) the estimates for the $\mathrm{HC}$ service as well as deciding most matters of policy. Also, it appoints the staff of the $\mathrm{HC}$ and determines their pay, pensions and other conditions of service. ${ }^{318}$

In conclusion, this Act should be consolidated into a Parliament Act.

\section{(i) Parliamentary Corporate Bodies}

The legislation which regulates the above is as follows:

- Parliamentary Corporate Bodies Act 1992. This contains the following s 1 (establishment of a corporation to be known as 'the Corporate Officer of the [HL]'; 2 (establishment of a corporation to be known as 'the Corporate Officer of the [HC]; 3 (schemes for the transfer of property etc to the corporations); 4 (transferred staff); 5 (schemes and transfers: supplementary provisions); 6 (gifts to either house to take effect as gifts to corporate officers).

This legislation provides for corporate officers for the $\mathrm{HL}$ and the $\mathrm{HC}$ who undertake functions in respect of the administration of the same. If the HL is abolished, then, the HC Commission could assume the functions of the HC corporate officer - to save time, money and administration.

In conclusion, this Act should be consolidated into a Parliament Act.

\section{(j) Parliamentary Joint Departments}

The legislation which regulates the above is as follows:

- $\quad$ Parliamentary (Joint Departments) Act 2007. This contains the following s 1 (joint departments); 2 (exercise of functions of the corporate officers); 3 (staff); 4 (staff transfers); 5 (application of enactments).

If the $\mathrm{HL}$ is abolished, the HC Commission could assume the functions of the HC department - to save time, money and administration.

In conclusion, this Act should be consolidated into a Parliament Act.

\section{(k) Acts of Parliament}

The legislation which regulates the above is as follows:

\footnotetext{
${ }^{316}$ Ibid, pp 14-5.

${ }^{317}$ Ibid, pp 109-110.

${ }^{318}$ Ibid, p 110 'The Commission employs the staff of the house (other than the clerk, clerk assistant, the sarjeant at arms and the speaker's personal staff)...'
} 
Acts of Parliament (Commencement) Act 1793 (Clerk of the Parliaments to indorse on every Act the time it receives the royal assent, which shall be its commencement, where no other is provided). It states:

'For remedy whereof the clerk of the Parliaments shall endorse (in English) on every Act of Parliament which shall pass after the $\left[8^{\text {th }}\right.$ April 1793 , immediately after the title of such Act, the day, month and year when the same shall have passed and shall have received the royal assent; and such endorsement shall be taken to be part of such Act.' The wording underlined is spent.

- Crown Debts Act 1801. s 9 (the statutes of England, and of [GB], printed and published by the printer duly authorised by [HM], shall be received as evidence in any court in Ireland, and the statutes of Ireland, prior to the union, so printed and published, shall be evidence in any court in $[G B)$ states: And for the better and more effectual proof of the statute law of the kingdoms of [GB] and Ireland, and of England and Ireland, previous to the union of the said kingdoms, in all courts of civil and criminal jurisdiction in every part of the said [UK];

the copy of the statutes of the kingdom of England, and of the kingdom of [GB] since the union with Scotland, printed and published by the printer duly authorized to print and publish the same by [HM], or by any of his royal predecessors, shall be received as conclusive evidence of the several statutes made and enacted prior to the union of the kingdoms of [GB] and Ireland by the Parliaments of England and [GB] respectively, in all suits, actions, or prosecutions respectively commenced, instituted, or carried on, or to be commenced, instituted, or carried on in any court of civil or criminal jurisdiction in Ireland;

and in like manner the copy of the statutes of the kingdom of Ireland, made and enacted by the Parliament of the same prior to the union of the kingdoms of [GB] and Ireland, and printed and published by the printer duly authorized by [HM], or any of his royal predecessors, to print and publish the same, shall be received as conclusive evidence of the several statutes made and enacted by the Parliament of Ireland prior to the union of the kingdoms of [GB] and Ireland, in all suits, actions, or prosecutions respectively commenced, instituted, or carried on, or to be commenced, instituted, or carried on in any court of civil or criminal jurisdiction in [GB].

Acts of Parliament (Expiration) Act 1808. S 1 (when bills for continuing expiring Acts shall not pass before the Acts expire, such Acts shall be continued from their expiration) states:

Where any bill may have been or shall be introduced into this present or any future session of Parliament for the continuance of any Act which would expire in such sessions, and such Act shall have expired before the bill for continuing the same shall have received the royal assent, such continuing Act shall be deemed to have taken effect from the date of the expiration of the Act intended to be continued as fully and effectually, to all intents and purposes, as if such continuing Act had actually passed before the expiration of such Act, except that it shall be otherwise especially provided in such continuing Act: provided nevertheless, that nothing herein contained shall extend or be construed to extend to effect any person or persons with any punishment, penalty, or forfeiture whatsoever, by reason of anything done or omitted to be done by any such person or persons contrary to the provisions of the Act so continued, between the expiration of the same and the date at which the Act continuing the same may have received or shall receive the royal assent.

- $\quad$ Short Titles Act 1896. This contains s 1 (citation of Acts in schedule 1); 2 (collective titles); 3 (effect of repeal of enactments giving short title).

- $\quad$ Acts of Parliament Numbering and Citation 1962. This contains s 1 (numbering and citation of future Acts) 'The chapter numbers assigned to Acts of Parliament passed in [1963] and every subsequent year shall be assigned by reference to the calendar year, and not the session, in which they are passed; and any such Act may, in any Act, instrument or document, be cited accordingly.'

In conclusion, these Acts should be consolidated into a Parliament Act. It may be noted that the wording of the 1801 Act may be greatly simplified. And, that the Act of 1896 may be repealed - without prejudice to the short titles accorded therein.

\section{(l) Laving Documents before Parliament}

The Laying of Documents before Parliament (Interpretation) Act 1948, s 1 states (meaning of references to laying before Parliament):

(1) For the removal of doubt it is hereby declared that a reference in any Act of Parliament, retained direct EU legislation or subordinate legislation, whether passed or made before or after the passing of this Act, to the laying of any instrument, report, account or other document before either house of Parliament is, unless the contrary intention appears, to be construed as a reference to the taking, during the existence of a Parliament, of such action as is directed by virtue of any Standing Order, Sessional Order or other direction of that house for the time being in force to constitute the laying of that document before that House, or as is accepted by virtue of the practice of that house for 
the time being as constituting such laying, notwithstanding that the action so directed or accepted consists in part or wholly in action capable of being taken otherwise than at or during the time of a sitting of that House; and that a reference in any such Act, retained direct EU legislation or subordinate legislation to the laying of any instrument, report, account or other document before Parliament is, unless the contrary intention appears, to be construed accordingly as a reference (construed in accordance with the preceding declaration) to the laying of the document before each house of Parliament.

(1A) A reference in any enactment to laying any document before the National Assembly for Wales is (unless the contrary intention appears) to be construed as a reference to the taking, during any time when that Assembly is not dissolved, of such action as is specified in the standing orders of that Assembly as constituting the laying of a document before that Assembly, even if the action so specified consists (wholly or partly) of action capable of being taken when that Assembly is in recess.

(2) It is hereby further declared that nothing in [s 4] of the Statutory Instruments Act 1946, is to be taken as indicating an intention that any reference in that section to the laying of copies of certain statutory instruments as therein mentioned is to be construed otherwise than in accordance with the preceding declaration.

S 2 (Statutory Instruments Act 1946, s.4: notification during vacancy of office of Speaker of either House) states:

It is hereby declared that the requirement imposed by [s 4(1)] of the Statutory Instruments Act 1946, to send notification forthwith to the Speaker of the $[\mathrm{HC}]$ and the Speaker of the [HL] where a statutory instrument required to be laid before Parliament has been made so as to come into operation before it has been so laid, is to be treated as having been complied with, in a case in which notification forthwith is impossible by reason of a vacancy for the time being in the office of the Speaker of the $[\mathrm{HC}]$ or the Speaker of the [HL], whether occurring by death, resignation, dissolution of Parliament or otherwise, if the notification is sent to him immediately after the vacancy is filled.

In conclusion, this Act should be consolidated into a Parliament Act.

\section{(m) Parliamentary Papers}

The Parliamentary Papers Act 1940, s 1 (proceedings, criminal or civil, against persons for publication of papers printed by order of Parliament, to be stayed upon delivery of a certificate and affidavit to the effect that such publication is by order of either House of Parliament) states: ${ }^{319}$

It shall and may be lawful for any person or persons who now is or are, or hereafter shall be, a defendant or defendants in any civil or criminal proceeding commenced or prosecuted in any manner soever, for or on account or in respect of the publication of any such report, paper, votes, or proceedings by such person or persons, or by his, her, or their servant or servants, by or under the authority of either house of Parliament, to bring before the court in which such proceeding shall have been or shall be so commenced or prosecuted, or before any judge of the same (if one of the superior courts at Westminster), first giving [24] hours' notice of his intention so to do to the prosecutor or plaintiff in such proceeding, a certificate under the hand of the Speaker of the [HL], or of the clerk of the Parliaments, or of the speaker of the $[\mathrm{HC}]$, or of the clerk of the same house, stating that the report, paper, votes, or proceedings, as the case may be, in respect whereof such civil or criminal proceeding shall have been commenced or prosecuted, was published by such person or persons, or by his, her, or their servant or servants, by order or under the authority of the [HL] or of the $[\mathrm{HC}]$, as the case may be, together with an affidavit verifying such certificate; and such court or judge shall thereupon immediately stay such civil or criminal proceeding; and the same, and every writ or process issued therein, shall be and shall be deemed and taken to be finally put an end to, determined, and superseded by virtue of this Act.

S 2 (proceedings to be stayed when commenced in respect of a copy of an authenticated report, \&c) states:

In case of any civil or criminal proceeding hereafter to be commenced or prosecuted for or on account or in respect of the publication of any copy of such report, paper, votes, or proceedings, it shall be lawful for the defendant or defendants at any stage of the proceedings to lay before the court or judge such report, paper, votes or proceedings, and such copy, with an affidavit verifying such report, paper, votes, or proceedings, and the correctness of such copy, and the court or judge shall immediately stay such civil or criminal proceeding; and the same, and every writ or process issued therein, shall be and shall be deemed and taken to be finally put an end to, determined, and superseded by virtue of this Act.

S 3 (in proceedings for printing any extract or abstract of a paper, it may be shewn that such extract was bona fide made) states:

It shall be lawful in any civil or criminal proceeding to be commenced or prosecuted for printing any extract from or abstract of such report, paper, votes, or proceedings, to give in every such report, paper, votes, or proceedings,

\footnotetext{
${ }^{319}$ See also May (2019), n 4, ch 7.
} 
and to show that such extract or abstract was published bonâ fide and without malice; and if such shall be the opinion of the jury, a verdict of not guilty shall be entered for the defendant or defendants.

S 4 (Act not to affect the privileges of Parliament):

Provided always, that nothing herein contained shall be deemed or taken, or held or construed, directly or indirectly, by implication or otherwise, to affect the privileges of Parliament in any manner whatsoever.

This Act resulted from the publication of Hansard when it was asserted that it contained libellous material. ${ }^{320}$ The wording should be placed in a Parliament Act, as modernised. ${ }^{321}$ Also, a Parliament Act should require Parliament to place online (with wordsearch) all Parliamentary papers (including Parliamentary returns, see (n)). Such would save costs as well increase the transparency - and the public's understanding - of Parliament (it would not prevent publishers providing hard copies of the same).

In conclusion, this Act should be consolidated into a Parliament Act.

\section{(n) Parliamentary Returns}

The Parliamentary Returns Act 1869, s 2 (discontinuance by Treasury of separate returns) states: 322

Whenever it appears to the Commissioners of [HM's] Treasury that any account, statement, return, or document required by any Act of Parliament or otherwise to be laid before one or both houses of Parliament contains the same information as or less information than is contained in the resource accounts prepared under the Government Resources and Accounts Act 2000, or in any account, statement, return, or document which is annually laid before one or both houses of Parliament, or that the same has otherwise become obsolete, such Commissioners may by minute direct that after the date of such minute coming into operation the account, statement, return, or other document therein mentioned shall be discontinued, and upon the minute coming into operation the same shall be discontinued accordingly, and shall not be prepared or laid before either house of Parliament.

S 3 (minutes to be submitted to Parliament) states:

Every minute so made by the Treasury shall be laid before both houses of Parliament as soon as may be after it is made, and shall not come into operation until it has lain before Parliament for [30] days on which either house of Parliament has actually sat, or until such later date as may be in that behalf prescribed in the minute, and shall not come into operation at all if during such [30 days] days a resolution against its so coming into operation is passed by either house of Parliament.

A Parliament Act should require Parliament to periodically review all its Parliamentary papers. And, to discontinue all those which are obsolete or which contain data otherwise available from other published sources.

In conclusion, this Act should be consolidated into a Parliament Act.

\section{(o) Parliamentary Costs}

The legislation which regulates the above is as follows:

- $\quad$ Parliamentary Costs Act 2006. It contains the following s 1 (functions of responsible officers); 2 (appointment of taxing officers); 3 (application for assessment); 4 (duty to assess - general); 5 (duty to assess special cases); 6 (report to responsible officer); 7 (complaints about report); 8 (certificate by responsible officer); 9 (award of costs to promoter of private bill); 10 (award of costs to petitioner opposing private bill); 12 (duty to assess and certify vexatious costs); 13 (functions of taxing officers); 14 (fees); 15 (application to other types of bill etc); 16 (court of referees); 18 (interpretation).

In conclusion, this Act should be consolidated into a Parliament Act.

\section{(p) Parliamentary Standards}

The legislation which regulates the above is as follows: ${ }^{323}$

- $\quad$ Parliamentary Standards Act 2009. It contains s 1 (Bill of Rights); 2 (HL); 3 (Independent Parliamentary Standards Authority (IPSA) etc); 3A (general duties of the IPSA); 4 (MP's salaries); 4A (determination of MPs salaries); 5 (MPs allowances scheme); 6 (dealing with claims under the scheme); 6A (review of IPSAs determination); 7 (information and guidance); 8 (MP's code of conduct relating to financial interests); 9 (investigations); 9A (procedures); 9B (enforcement); 10 (offence of providing false or misleading information for

\footnotetext{
${ }^{320}$ See May (in 1844), n 3, pp 125-130. Also, pp 60-62. This Act should also be considered in light of the following, see May (2019), n 3, p 293 'The [HC] agreed in 1971 that to rescind their ban on the publication of their debates and proceedings or those of any committee.'

${ }^{321}$ Munro noted, n 43, p 238 the Joint C-ee on Parliamentary Privilege 1997 recommended the replacement of this Act with modern provisions.

${ }^{322}$ For the process of Parliamentary returns in 1844, prior to this Act, see May (in 1844), n 3, pp 309-16. See also May (2019), n 4, pp 156-7.

${ }^{323}$ See also May (2019), n 4, p 130. The IPSA administers members salaries and expenses.
} 
allowance claims); 10A (relationship with other bodies etc); 11 (further functions of the IPSA and Commissioner); 12 (interpretation); 13 (power to make transitional etc provision).

In conclusion, this Act should be consolidated into a Parliament Act.

\section{(q) Parliamentary Pensions}

The Parliamentary and Other Pensions Act 1972 - as amended by the Parliamentary and other Pensions and Salaries Act 1976 and the Parliamentary Pensions etc Act 1984 - was replaced by the Public Service Pensions Act 2013. Thus, it is asserted that a Parliament Act does not need to deal with Parliamentary pensions.

\section{(r) Parliamentary Oaths}

The legislation which regulates the giving of oaths in Parliament is as follows:

- $\quad$ Parliamentary Witnesses Act 1858. S 1 (oath) 'Any committee of the [HL] may administer an oath to the witnesses examined before such committee.'

- $\quad$ Parliamentary Oaths Act 1866. This Act provides: s 1 (oath to be taken by MPs), 3 (time and manner of taking the oath), s 5 (penalty for omissions).

- $\quad$ Parliamentary Witnesses Oaths Act 1871. S 1 (examination of witnesses on oath by the [HC] and Committees of the House) states:

The $[\mathrm{HC}]$ may administer an oath to the witnesses examined at the bar of the said House. Any committee of the $[\mathrm{HC}]$ may administer an oath to the witnesses examined before such committee. Any oath under this Act may be administered by the Speaker of the [HC], or by such person or persons as may from time to time be appointed for that purpose either by him or by any Standing Order or other Order of the said house.

S 3 (as to additional power or privilege of the [HC]), states:

Nothing in this Act contained shall be held to confer any additional or further power or privilege on the $[\mathrm{HC}]$ with reference to impeachment or other criminal jurisdiction or otherwise howsoever than is herein expressly enacted.

The Act of 1858 (which deals with HL committees) should be replaced with the wider formulation contained in the Act of 1871 ( $\mathrm{s} 3$ of which is now spent). Consideration should, also, be given to the abolition of all Parliamentary oaths $\mathrm{s}^{324}$ or - where required - the same being in the form of an affirmation. It may be noted that taking the oath is an involved process, taking time and resulting in penalties if not taken. ${ }^{325}$ It should also be noted that oaths, generally, were never legally - but only morally binding. Also, their nature involves a belief in a deity. ${ }^{326}$

In conclusion, this Act should be consolidated into a Parliament Act.

\section{(s) Courts}

The courts are part of the constitution in a wider sense. However, for a long time, distinct legislation has applied to the same and it is appropriate that - when Parliament is acting as a court - such be contained in a Courts Act, rather than dealt with in a Crown Act or a Parliament Act. Thus, material in the Constitutional Reform Act 2005 on the courts should be placed in a Courts Act, which Act should also deal with the following in relation to Parliament, its power to:

$$
\begin{aligned}
& \text { - } \text { act as a court; } \\
& \text { - imprison; } \\
& \text { - arrest; } \\
& \text { - fine. }
\end{aligned}
$$

\section{(t) Chequers \& Chevening Estates}

As to these:

- $\quad$ Chequers is the country home of the Prime Minister since 1921. It was granted to the nation by Sir Arthur Lee by a deed of settlement contained in the Chequers Act 1917, see s 1 (deed of settlement; 3 (provision as to taxes and duties); 3A (stamp duty land tax). This Act was amended and supplemented by the Chequers Act 1958, see s 1 (amends 1917 Act); 2 (exchequer grants to administrative trustees); s 3 (supplementary provisions).

- Chevening Estate. Chevening house and estate serve as a country residence for a person nominated by the PM. This is, usually, the Secretary of State for Foreign and Commonwealth Affairs. They are owned and maintained by the

\footnotetext{
${ }^{324}$ See GS McBain, Modernising the Law on Oaths and Affirmations [2020] Int. Law Research, vol 9, no 1, pp 1-55.

${ }^{325}$ May (2019), n 4, pp 174-8.

${ }^{326}$ See n 324.
} 
trust for the Chevening Estate under the Chevening Estate Act 1959. See s 1 (confirmation of vesting deed and trust instrument), s 2 (provisions as to income tax, estate duty and stamp duty), 2A (stamp duty land tax). This Act was amended by the Chevening Act 1987, see s 1 (incorporation of function of the board of trustees); 2 (transfer of assets); 3 (amends trust instrument), 4 (amends 1959 Act).

In conclusion, these Acts should be consolidated in a schedule to a Parliament Act

\section{(u) Statute of Westminster 1931}

This Act made provision in respect of various countries which were, formally, dominion countries (i.e. part of the British Empire) - viz. Australia, Canada, Irish Free State and New Zealand ('NZ'). Thus,

$\mathbf{S} \mathbf{1}$ (meaning of "Dominion" in this Act). In this Act the expression "dominion" means any of the following dominions, that is to say, the dominion of Canada, the Commonwealth of Australia, the dominion of NZ, the Irish Free State and Newfoundland.

S 2 (validity of laws made by Parliament of a dominion), 1) The Colonial Laws Validity Act 1865 shall not apply to any law made after the commencement of this Act by the Parliament of a dominion. (2) No law and no provision of any law made after the commencement of this Act by the Parliament of a dominion shall be void or inoperative on the ground that it is repugnant to the law of England, or to the provisions of any existing or future Act of Parliament of the [UK], or to any order, rule or regulation made under any such Act, and the powers of the Parliament of a dominion shall include the power to repeal or amend any such Act, order, rule or regulation in so far as the same is part of the law of the dominion.

S 3 (power of Parliament of Dominion to legislate extra-territorially). It is hereby declared and enacted that the Parliament of a dominion has full power to make laws having extra-territorial operation.

S 4 (Parliament of [UK] not to legislate for Dominion except by consent). No Act of Parliament of the [UK] passed after the commencement of this Act shall extend, or be deemed to extend, to a dominion as part of the law of that dominion, unless it is expressly declared in that Act that that dominion has requested, and consented to, the enactment thereof.

S 6 (powers of Dominion Parliaments in relation to Courts of Admiralty). Without prejudice to the generality of the foregoing provisions of this Act, Colonial Courts of Admiralty Act 1890, [s 4] (which requires certain laws to be reserved for the signification of [HM's]pleasure or to contain a suspending clause) ${ }^{327}$ and so much of [s 7] as requires the approval of [HM] in Council to any rules of court for regulating the practice and procedure of a Colonial Court of Admiralty, shall cease to have effect in any dominion as from the commencement of this Act.

S 7 (saving for British North America Acts and application of the Act to Canada). (1) Nothing in this Act shall be deemed to apply to the repeal, amendment or alteration of the British North America Acts 1867 to 1930 or any order, rule or regulation made thereunder. (2) The provisions of [s 2] of this Act shall extend to laws made by any of the Provinces of Canada and to the powers of the legislatures of such Provinces. (3) The powers conferred by this Act upon the Parliament of Canada or upon the legislatures of the Provinces shall be restricted to the enactment of laws in relation to matters within the competence of the Parliament of Canada or of any of the legislatures of the provinces respectively.

s 8 (saving for Constitution Acts of Australia and New Zealand). Nothing in this Act shall be deemed to confer any power to repeal or alter the Constitution or the Constitution Act of the Commonwealth of Australia or the Constitution Act of the Dominion of [NZ] otherwise than in accordance with the law existing before the commencement of this Act.

S 9 (saving with respect to States of Australia). (1) Nothing in this Act shall be deemed to authorise the Parliament of the Commonwealth of Australia to make laws on any matter within the authority of the States of Australia, not being a matter within the authority of the Parliament or Government of the Commonwealth of Australia. (2) Nothing in this Act shall be deemed to require the concurrence of the Parliament or Government of the Commonwealth of Australia in any law made by the Parliament of the [UK] with respect to any matter within the authority of the States of Australia, not being a matter within the authority of the Parliament or Government of the Commonwealth of Australia, in any case where it would have been in accordance with the constitutional practice existing before the commencement of this Act that the Parliament of the [UK] should make that law without such concurrence. (3) In

\footnotetext{
${ }^{327} \mathrm{~S} 4$ (reservation of Colonial law for [HM's] assent). 'Every colonial law which is made in pursuance of this Act, or affects the jurisdiction of or practice or procedure in any court of such possession in respect of the jurisdiction conferred by this Act, or alters any such colonial law as above in this [s] mentioned, which has been previously passed, shall, unless previously approved by [HM] through a Secretary of State, either be reserved for the signification of [HM's] pleasure thereon, or contain a suspending clause providing that such law shall not come into operation until [HM's] pleasure thereon has been publicly signified in the British possession in which it has been passed.'
} 
the application of this Act to the Commonwealth of Australia the request and consent referred to in [s 4] shall mean the request and consent of the Parliament and Government of the Commonwealth.

S 10 (certain sections of Act not to apply to Australia, [NZ] or Newfoundland unless adopted). (1) None of the following sections of this Act, that is to say, [ss 2-6] shall extend to a dominion to which this [s] applies as part of the law of that dominion unless that [s] is adopted by the Parliament of the dominion, and any Act of that Parliament adopting any [s] of this Act may provide that the adoption shall have effect either from the commencement of this Act or from such later date as is specified in the adopting Act. (2) The Parliament of any such dominion as aforesaid may at any time revoke the adoption of any section referred to in [ss (1)].(3) The Dominions to which this section applies are the Commonwealth of Australia, the Dominion of New Zealand and Newfoundland.

This Act is now some 90 years old and the UK no longer legislates for dominion countries (which are no longer termed as such). Thus, this Act should be repealed as spent. ${ }^{328}$

\section{In conclusion, this Act should be repealed.}

\section{PROCEDURE FOR PASSING BILLS}

In Victorian times, bills of Parliament were categorised as: (a) public bills; and (b) private bills ${ }^{329}$ - albeit, there was also a practical categorisation of bills into public, private and hybrid. ${ }^{330}$ However, as May (in 1844) noted:

the progress of private bills is entangled by so many peculiar regulations and standing orders, in both houses, that an entire separation of the two classes can alone make the progress of either intelligible. ${ }^{331}$

In more modern times, bills of Parliament were categorised into general, local and private bills - although this classification appears to have dropped away, today, with local bills now being called private bills on the Parliament website and in May (2019 edition). ${ }^{332}$

- $\quad$ This may be partly explained by the fact that both private bills and local bills are now rare. ${ }^{333}$ Indeed, there have been no personal (private) bills since 1987 (more than 30 years ago). And, no local (private) bills in 2017 and 2018. ${ }^{334}$

- Yet, May (2019) still contains a huge wodge on local and private bills - nearly 220 pages - indicating the complexity in processing them.

There is no good reason why the procedure for private bills cannot be simplified and made the same, in most features, ${ }^{335}$ as that of public bills. Alternatively, it is suggested that the distinction between public and private bills be abolished and that the latter should now be treated as public bills. Not least, since there are likely to be few of them in the future - perhaps, 2-3 a year at most. However, in the case where the Speaker of the Commons considers that the content of the private bill submitted is likely to be contentious, there should be an (uncomplicated) system of initial Parliamentary scrutiny (also, in both cases, only two readings). ${ }^{336}$ Abolition of the distinction will also abolish the (relatively new) concept of a 'hybrid' bill. ${ }^{337}$

In conclusion, Bills should be classified into (a) public; (b) private. The process for both should be simplified, to the greatest extent possible (with non-contentious private bills having only 2 readings). Alternatively, any distinction between public and private bills should be abolished (save for only 2 readings in the case of non-contentious private bills).

\footnotetext{
${ }^{328}$ The Colonial Laws Validity Act 1865 and the Colonial Courts of Admiralty Act 1890 (still extant) should be modernised, it also being provided that neither apply to the former dominion status of Australia, Canada, the Irish Free State and NZ.

${ }^{329}$ e.g. May (in 2019), n 4, p 271 'Bills are divided into the two classes, of public and private bills; of which the former are introduced directly by members of the house, while the latter are founded upon the petitions of parties interested.'

${ }^{330}$ See May (in 1844), ch 3 . The 3 classes of private bill are now, mostly, under statutory powers. So too, railway bills. Inclosure Acts ended by the early 20th century (when the policy of inclosure changed to one of management).

${ }^{331}$ Ibid, p 271. See also pp 383-460, at p 384 'the proceedings of Parliament in passing private bills are still marked by much peculiarity.'

${ }^{332} \mathrm{Ibid}, \mathrm{p} 1091$ 'Private legislation is legislation of a special kind for conferring particular powers or benefits on any person or body of persons - including individuals, local authorities, companies, or corporations - in addition to or in conflict with the general law....The essential difference in procedure between a public bill and a private bill is that a public bill is either presented direct to one or other house or introduced on a motion by a member of either house, while a prívate bill is sought by the parties who are interested in promoting it and is founded upon a petition which must be deposited in accordance with standing orders. There are also fees charged in the case of prívate bills, on the promoters.'

${ }^{333}$ Private Acts from 1539-1987 (there have been none thereafter). Local Acts are from 1797.

${ }^{334}$ May (2019), n 4, p 1092 'no petitions were deposited in 2017 and 2018'. Ibid, p 1180 'Personal bills are prívate bills that relate to the 'estate, property, status or style, or otherwise to the personal affairs of an individual'...Such bills are now rare: none have been enacted since 1987.'

${ }^{335}$ Ibid, p 386 'when they [private bills] come before either house, they are treated precisely as if they were public bills. They are read as many times, the questions put concerning them differ in no respect whatever; and the same rules of debate and procedure are maintained throughout.'

${ }^{336}$ Ibid, p 1101 (re Planning Act 2008, a useful innovation).

${ }^{337}$ Ibid, pp 769-70.
} 


\section{TREATIES}

The Constitutional Reform and Governance Act 2010 contain certain sections on the Civil Service. These should be placed in a Government Act. ${ }^{338}$ It also contains sections on the following, which should be placed in a Parliament Act:

- $\quad$ Treatises. Sections 20-5 provide for treaties to be laid before Parliament. ${ }^{339}$

- Taxation of MP's and Peers. S 41 (tax staus of MPs and members of the [HL]) states: (1) [ss] (2) applies if a person is for any part of a tax year: (a) a member of the [HC], or (b) a member of the [HL]. (2) The person is to be treated for the purposes of the taxes listed in [ss] (3) as resident and domiciled in the [UK] for the whole of that tax year. (3) The taxes are - (a) income tax, (b) capital gains tax, and (c) inheritance tax. ${ }^{340}$

This material should be placed in a Parliament Act.

\section{APPOINTMENT OF PRIME MINISTER}

The Prime Minister (the 'PM') is appointed by the sovereign. ${ }^{341}$ The position as to this is as follows:

- Majority in the HC. The convention is that the sovereign appoints the person who is the leader of the political party which can command a majority in the HC. If a PM resigns while his government has a majority, it is for his party to elect his successor - who will be appointed by the sovereign.

- Hung Parliament. If there is no overall majority (i.e. a hung Parliament) the incumbent PM remains in office until he tenders his (and his government's) resignation to the sovereign. He may wait until the meeting of a new Parliament to see whether he can command a majority. If he cannot (or is defeated on the Address at the meeting of a new session of Parliament) the leader of the largest opposition party in the HC will be appointed PM by the sovereign. ${ }^{342}$

By convention, a PM sits in the HC while PM even if he (or she) is entitled to sit in the HL. ${ }^{343}$

The above should be stipulated in a Parliament Act.

\section{APPOINTMENT OF MINISTERS}

The PM advises the sovereign on the appointment, dismissal and resignation of ministers of the Crown. However, the mode of appointment by the sovereign differs (without good reason) in that:

- $\quad$ some ministers receive seals of office - the appointment taking effect by delivery of the same;

- $\quad$ other ministers receive letters of patent;

- $\quad$ other ministers receive a royal warrant;

- other minister's appointments take effect when the sovereign accepts the PM's recommendation on the appointment. ${ }^{344}$

It would seem sensible to streamline the administration in respect of Crown appointments and make them more consistent. Therefore, it is suggested that the above be dispensed with and that all ministers of the Crown be appointed (or dismissed or

\footnotetext{
${ }^{338}$ See ss 1-18. It also contains sections (26-38) amending the Parliamentary Standards Act 2009 (see 19(p)).

${ }^{339}$ See s 20 (treaties to be laid before Parliament before ratification), s 21 (extension of 21 day sitting period), s 22 ( 20 not to apply in exceptional cases), s 23 (s 20 not to apply to certain descriptions of treaties), s 24 (explanatory memoranda), s 25 (meaning of 'treaty' and 'ratification. '). See also May (in 2019), n 4, p 159.

${ }^{340}$ It continues: (4) For the purposes of this [s] a person - (a) becomes a member of the [HC] when (having been elected to that house) the person makes and subscribes the oath required by the Parliamentary Oaths Act 1866 (or the corresponding affirmation), and (b) ceases to be a member of that house when - (i) the Parliament to which the person was elected is dissolved, or (ii) the person's seat is otherwise vacated. (5) For the purposes of this [s] and [s] 42 a person is a member of the [HL] if the person is entitled to receive writs of summons to attend that house. (6) In relation to a member of the [HL], in [ss] (1) the reference to any part of a tax year excludes any part of the year during which (a) [s] 137(3) of the Constitutional Reform Act 2005 applies to the member, or (b) the member is entitled to receive writs of summons to attend the [HL] by virtue of being an archbishop or bishop. (7) This [s] applies in relation to the tax year 2010-11 and subsequent tax years. (8) But in applying this [s] to the tax year 2010-11 - (a) if the Parliament in which this Act is passed is dissolved in that tax year, ignore a person's membership of the [HC] in that Parliament, and (b) in any event, ignore a person's membership of the [HL] at any time before the end of the period of 3 months beginning with the day on which [s] 42 comes into force. (9) In this [s], in relation to inheritance tax - (a) "tax year" means a year beginning on 6 April and ending on the following 5 April, and (b)"the tax year 2010-11" means the tax year beginning on 6 April 2010. (10) In determining for the purposes of this section and section 42 whether a person is entitled to receive writs of summons to attend the [HL] ignore - (a) [s] 2 of the Forfeiture Act 1870; (b) [ss] 426A and 427 of the Insolvency Act 1986.

${ }^{341}$ Halsbury $\left(5^{\text {th }} \mathrm{ed}\right), \mathrm{n} 222$, vol 29 , para 51 'The most important of the monarch's direct prerogative powers today is the appointment of a [PM] who serves as head of the government. While in former times the monarch's personal judgment and discretion played a role in the choice of the [PM], today this role and function of the royal head of State is performed exclusively in accordance with established procedures and convention.'

${ }^{342}$ Ibid.

${ }^{343}$ Ibid.

${ }^{344}$ Ibid, para 54
} 
their resignation accepted) by means of a formal letter from the PM. And, that the sovereign no longer be involved in such not least, since her role is purely formal today and she has no power to refuse to appoint or dismiss (or accept the resignation) of a minister. ${ }^{345}$

In conclusion, a Parliament Act should specify that the PM appoints and dismisses ministers of the Crown-as well as accepts their resignation - by way of a formal letter from the same.

\section{CONTEMPTS OF PARLIAMENT}

In a useful chapter, May (2019) considers contempts, also noting that - in 1978 - the HC 'resolved to exercise its penal jurisdiction as sparingly as possible. ${ }^{346} \mathrm{As}$ it is, it is possible to usefully list contempts by reference to the person(s) against whom they are directed (or who cause the same), viz.

- MPs

- Members of the HL

- Parliamentary Officers

- $\quad$ Staff

- Witnesses

- Constituents

- Committees (general and select)

- $\quad$ Members of the public

It is also possible to categorise the forms of contempt under certain headings:

- Crimes (including physical violence, intimidation (threats), bribery, corruption, etc)

- Breach of Parliament's rules and practices

- Publishing false (or inaccurate) reports

- Unauthorised disclosure of Parliamentary proceedings and papers

- Unacceptable Parliamentary behaviour (e.g. abuse, misrepresentation, molestation etc) ${ }^{347}$

- Intercepting communications

- Improper influence

- Tampering and interference (with witnesses etc)

- Legal proceedings

- Other misconduct

These contempts should be set out in an SI, together with the relevant punishment.

- Why contempts of Parliament should be set out in an SI (as opposed to being, at present, an uncertain Parliamentary practice or procedure) is that such being a form of legislation, it overcomes uncertainty as to what these contempts are and whether the HC or HL (severally or jointly) has the inherent power to impose the same - whether as a court of record ${ }^{348}$ or otherwise.

- Further, being an SI, the English High Court can interpret the same - and whether the relevant contempt had been committed - without trespassing on the authority of Parliament to regulate its own affairs.

It is suggested that listing these contempts and indicating the level of fine (on a standard scale, such as normally applies) would not be difficult. Nor, in most cases, contentious. It would also help distinguish between 'contempts of Parliament' and crimes - which the police (with their power to arrest and imprison) should be left to cover.

In conclusion, a SI should set out all contempts of Parliament and the penalty, which SI may be updated from time to time.

\footnotetext{
${ }^{345}$ An alternative would be for the Crown to notify by way of proclamation since this would, at least, fix the time and date of the appointment etc and it could deal with a number of ministers. However, since the role of the sovereign is purely formal, such (while easier to effect than handing over seals etc) use of a proclamation is not appropriate.

${ }^{346}$ May (2019), n 4, p 289.

${ }^{347}$ Such would not cover criminal offences.

${ }^{348}$ Is the HC a court of record? This is contentious since the definition of such is a court with the power to fine and imprison and it is not clear whether the HC has had the latter. See also May (2019), n 4, p 330 referring to fn 11 (Stockdale v Hansard (1839) 112 ER 1112 'The Commons was not a court of law in the sense recognised in the courts, and was unable to decide a matter judically in litigation between parties, either orginally or by appeal.'
} 


\section{ERSKINE MAY}

The first edition of Erskine May, A Treatise upon the Law, Privileges, Proceedings and Usage of Parliament in 1844 was a ground breaking work and a useful guide to the privileges and practices of Parliament. The $25^{\text {th }}$ edition (2019) is similarly useful, but expensive, and, therefore, beyond the pockets of many people. Any future editions should be put online on a Parliamentary website at no cost (with word search) - without prejudice to any hard copy edition. It may be noted that the Speaker's Commission on Digital Democracy, in a 2015 report, recommended that:

Erskine May, the definitive guide to parliamentary procedure, should be freely available online by the time that the next edition is produced. ${ }^{349}$

Further, so much other material on Parliament is now online, as May (2019) notes:

Virtually all documents printed by Parliament are also published electronically and posted on the Parliamentary website. ${ }^{350}$

In conclusion, future editions of May's work should be available - free - on a Parliamentary website.

\section{PARLIAMENT IS FALLING DOWN!}

Structurally, Parliament is not in a good state and extensive repair is required. The opportunity should also be taken for Parliament to acquire the freehold of all the land on which Parliament sits. ${ }^{351}$

\section{(a) Ownership of the Palace}

- The palace of Westminster, in which the HC and HL meet, was founded by Edward the Confessor (1042-66). ${ }^{352}$ Thus, this land was owned by the Crown. Further, it is trite law that William I (1066-87) claimed title to all land in England. This included London and the ground within its Roman built walls (some 330 acres, the Roman walls having been built c. 200AD). London (in Anglo-Saxon, Londonburg) was a fortified town (a burg or burgh) whose citizens (c. 30,000 or so in 1066) held it from the Crown by way of an Anglo-Norman form of tenure (land holding) called burgage. That is, paying annual composite quit rent of, probably, $£ 300 \mathrm{pa}^{353}$ Thus, from 1066, the land on which Parliament stands was owned by the Crown. ${ }^{354}$

- However, in 1760, Crown land owned passed to the nation (the Crown Estate) the sovereign being compensated for any loss by receiving a civil list.

Today, Parliament should acquire any freehold in the palace of Westminister not held by the same, and hold it on behalf of the nation.

\section{(b) Control of the Palace}

In respect of any control of Westminster palace (the palace of Westminster), May (2019) states:

On 26 April 1965, with the consent of the queen, control of the palace passed to the two houses, except that control of Westminster Hall became vested jointly in the Lord Great Chamberlain [LGC] as representing [HM] and in the two speakers on behalf of the two houses. Invitations to foreign dignatories to address both houses will ordinarily be issued only by the agreement of all three keyholders. The [LGC] also retains his previous functions on royal occasions, and control of [HM's] robing room (and the staircase and ante-room adjoining), the Royal Gallery and the Chapel of St Mary Undercroft remains in his hands. The Corporate Officers of both houses have been able to acquire, hold, manage and dispose of land and other property since 1992, by virtue of the Parliamentary Corporate Bodies Act 1992. The accommodation used by the houses is a combination of freehold, leasehold and leased

\footnotetext{
${ }^{349}$ See Evans, n 4, pp 126-7.

${ }^{350}$ May (2019), n 4, p 161.

${ }^{351}$ The present Parliamentary buildings mainly date from 1834 when a great fire destroyed much of Parliament. It was then re-built in the period 1840-52. See May (2019), n 4, p 131. Also, HM Port, The Houses of Parliament (1976).

${ }^{352}$ In AD 886, king Alfred (AD 886-99) took the town of London from the Vikings and repaired the Roman walls. He held it as king (the 'Crown', but in his body politic since it did not pass in his will, details of which are extant, see FE Harmer, Select English Historical Documents (1914), p 15.

${ }^{353}$ This is reflected in a later charter of c. 1132 of Henry I to the citizens (buru waru) of London - the title recognising that they were freemen, not serfs or slaves. The rent was $£ 300$ p.a. It was a rent in fee farm (' $f e e$ ' meaning the fief or estate and the 'farm' deriving from the AngloSaxon, feorme - food rent - which was, in time, converted into a money rent). That is, this rent was based on the actual (or near thereto) value of the land in London as a whole. It was, also, a rent that was a quitrent (the only service being fealty to the king). Further, the tenants held directly from the king (in capite). Burgage in London only formally ended in 1929, when the rent was cancelled. See generally, McBain, $\mathrm{n} 1$, p 27, fns $123 \& 125$.

${ }^{354}$ Usually, Parliament met at Westminster, although there were meetings at York, Lincoln etc, see Stubbs, n 92, vol 3, pp 399-401, who lists them. Also, Sayles, n 92, pp 137-41 (1258-1377).
} 
buildings. Most of the buildings on the estate are historic and listed and sit within several conservation zones and sites of archaeological importance. The palace itself is located within a UNESCO world heritage site. ${ }^{355}$

Given the above, it would seem important that Parliament hold the freehold of all the land and buildings thereon, on behalf of the nation. Thus, the Crown Estate and the Crown (i.e. the sovereign in person or in the body politic) should be requested to give up any title (and control) to the same. This would enable Parliament to more readily maintain, and repair, Westminster palace.

In conclusion, Parliament should acquire control of the palace of Westminster - according the sovereign access, where required.

\section{CONCLUSION}

In an Irish case, McInerney $v$ Liddy (1945), Gavan Duffy J observed 'The law is not a mausoleum'. ${ }^{356}$ Clearly, he was not referring to the law on Parliament which is precisely that. A patchwork of antiquated law. Much of scant worth. Much of little use (or intelligibility) in modern times. In short, a model of obscurity ${ }^{357}$ Evans, in his text, states:

Lord Salisbury, later Prime Minister [1885-6, 1886-92, 1892-1902], was still complaining thirty years after the Reform Act [of 1832] that the proceedings of the [HC] were 'uncouth, complicated, often unmeaning, founded upon circumstances which have ceased to exist, often defensible by no reasons applicable to the present state of things, and liable at any time to misuse. ${ }^{358}$

So? Nothing has changed. The conclusion to this article may be succinctly stated:

- Legislation on Parliament (some c. 66 Acts) should be consolidated into 1 Parliament Act (see Appendix C);

- All Crown prerogatives relating to Parliament should be abolished as obsolete (most are) or put in legislation - if still required.

It is suggested that there is nothing difficult about this. In due course, a Crown Act and a Parliament Act can be consolidated into one Constitution Act, enabling further redundant material to be excised. Also, there is no doubt that, if the HL were abolished, such would simplify the removal of many obsolete Crown prerogatives, practices and legislation. An Act to provide for this would not be complex - the opposite (see Appendix D).

\section{APPENDIX A}

These texts are to be found in Sweet \& Maxwell (n 255), vols 1 and 2, up to 1957. Also inserted are some general texts on Parliament which provide useful background.

\section{$\underline{1500-1650}$}

Anon

E Coke

RB Cotton

RB Cotton

R Derham

S D'Ewes

H Elsynge

$\mathrm{H}$ Elsynge

R Filmer

W Hakewill

W Hakewill

D Jenkins

G Petyt

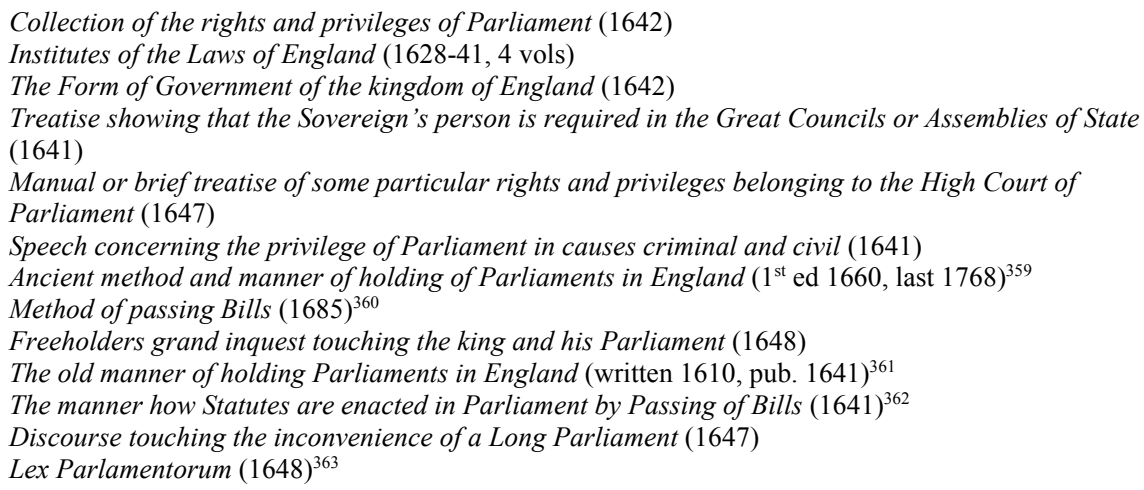

${ }^{355}$ May (2019), n 4, p 131.

${ }^{356}$ McInerney $v$ Liddy [1945] IR 100, 104 per Gavan Duffy J, cited in RE Megarry, Miscellany at Law (1955), p 166.

${ }^{357}$ Evans, n 4, p 2 quotes Coke (1628) who referred to the law and custom of Parliament as 'ab omnibus quaeranda, a multis ignoranda, a paucis cognita [asked after by everyone, unknown to many, understood by few].' This is still appropriate today. See also the observation of TE May in 1854, Ibid, p 6. Also, Onslow in the 18th century, Ibid, p 97.

${ }^{358}$ Evans, n 4, p 10.

${ }^{359}$ Ibid, p 130.

${ }^{360}$ Ibid.

${ }^{361}$ Pronay, n 23, p 54.

${ }^{362}$ See also Hakewill, Speaking in the House of Commons, see Evans, n 4, p 91.

363 or abstract of the antiquity and jurisdiction of the High Court of Parliament, according to the laws and constitutions of this realm. 
G Petyt

W Raleigh

H Scobell

H Scobell

H Scobell

H Spelman

T Smith

J Vowell (aka J Hooker)

\section{$\underline{1650-1700}$}

Anon

Anon

Anon

Anon

R Atkins

W Atwood

R Brady

A Bustard

RB Cotton

RB Cotton

RB Cotton

J Dodderidge

J Dodderidge

J Howell

W Lambarde

T May

T May

W Petyt

W Prynne

W Prynne

W Prynne

W Prynne

J Rushworth

W Ryley

T Rymer

J Selden

J Selden

T Sheridan

H Townsend

\section{$\underline{1700-1750}$}

\section{Anon}

R Acherley

R Atkins

W Brown(e)

T Gurdon

M Hale

N Hardinge (?)

H Hody

J Pettus

J Ralph (ed)

Lord Somers
Lex Parliamentaria (trans, 1690; last ed 1803) ) $^{364}$

Prerogative of Parliaments in England (1628)

Power of the Lords and Commons in Parliament in point of Judicature (1680)

Several Treatises of Parliament (1703)

Remembrances of the Methods... in the House of Lords (1657)

Of Parliaments (1642)

De Republica Anglorum (1583) $)^{365}$

Old and Ancient Order of keeping a Parliament in England (1572) ${ }^{366}$

Antiquity, Power and Decay of Parliaments (1681)

Consideration ... whether ...Parliament is dissolved by its prorogation for 15 months (1676)

Necessity of Parliaments: with seasonable directions for the more regular election of Parliament men (1679)

The Fundamental Laws and Liberties of this Kingdom (1653)

Power, Jurisdiction and Privilege of Parliament \& the antiquity of the House of Commons asserted (1689)

Jani Anglorum facies Nova $(1680)^{367}$

Introduction to the Old English History (1684)

Cessyos of Parliament (n.d.)

Antiquity and dignity of Parliaments (1680)

Brief discourse [re] power of the Peers and Commons of Parliament in point of Judicature

$\left(1^{\text {st }}\right.$ ed, $1640 ; 3^{\text {rd }}$ ed 1680$)$

Cottoni Posthuma (1679) 368

Journals of all the Parliaments held during the reign of Queen Elizabeth (1682)

Antiquity and Power of Parliaments (1679)

Opinions of some Learned Antiquaries touching the Antiquity etc of the High Court of Parliament in

England (1685) $)^{369}$

Pre-eminence and pedigree of Parliament (1677)

Notes on the Procedures of the House of Commons (1581)

Breviary of the History of the English Parliament $\left(1^{\text {st }}\right.$ ed, $1650 ; 3^{\text {rd }}$ ed 1680$)$

History of the Parliament of England which began Nov $3^{\text {rd }} 1640$ with a view of some precedent years

(1647)

Miscellanea Parliamentaria (1681)

First Part of an Historical Collection of the Antient Parliaments of England (1649)

Brief Register, Kalendar and Survey... of all Parliamentary Writs (1659)

Minors not Senators (1661)

Sovereign Power of Parliaments and Kingdoms (1643)

Historical Collections (1659 (for vol 1); last ed 1721 (8 vols))

Pleadings in Parliament... in the reigns of Edward I and Edward II (1661)

View of Government in Europe, also the Antiquity, Power and Decay of Parliaments (1689; $3^{\text {rd }}$ ed, 1715) Judicature in Parliaments (c. 1681) ${ }^{370}$

Brief Discourse concerning the power of Peers and Commons of Parliament in point of Judicature (1680)

Discourse of the Rise and Power of Parliaments (1677)

Historical Collections (1680)

History of Parliament (1745)

Free Parliaments $(1731)^{371}$

Parliamentary and Political Tracts $(1741)^{372}$

Privilegia Parliamentaria Senatus Consensu Sublata $(1704)^{373}$

History of the High Court of Parliament (1731)

Original institution, power and jurisdiction of Parliaments (1707)

Orders, Standing Orders and Resolutions of the honourable House of Commons (1747)

History of English councils... also the history of Parliaments (1701)

Constitution of Parliaments in England (1701)

Use and Abuse of Parliaments (1744)

Collection of Scarce and Valuable Tracts $\left(1^{\text {st }} \mathrm{ed}, 1748-51 ; 2^{\text {nd }}\right.$ ed, 1809-15)

\footnotetext{
${ }^{364}$ or treatise of the law and custom of the Parliament of England. Sometimes attributed to G Philips.

365 the manner of government or policy of the realm of England.

${ }^{366}$ reprinted in VF Snow, Parliament in Elizabethan England (1977). See also Evans, n 4, p 89. Also, Pronay, n 23 , p 52.

${ }^{367}$ or several monuments of anquity touching the general councils of the kingdom and the court of the king's immediate tenants and officers.

${ }^{368}$ wherein are discussed several important questions concerning the rights and powers of the Lords and Commons in Parliament.

369 These tracts are included in T Hearne, A collection of Curious Discourses (1775), vol 2.

${ }^{370}$ This has been attributed to S D'Ewes.

${ }^{371}$ or an argumento on their constitution, proving some of their powers to be independent.

372 This includes tracts on the power, jurisdiction and privilege of Parliament and the antiquity of the HC asserted.

${ }^{373}$ remarks upon the Acts of 12 \& 13 Will 3 [c 3, 1700] and $2 \& 3$ Anne [c 12, 1703] for preventing inconveniences by privilege of Parliament.
} 


\section{$\underline{1750-1800}$}

Anon

Anon

Anon

H Elsynge

THB Oldfield

R Wooddeson

\section{0-50}

W Bagehot

J Bentham

RW Bridgman

J Campbell

E Christian

SA Ferrall (O’Ferrall)

A Hammond

TD Hardy

J Hatsell

L Holt

A Luder

TE May

F Palgrave

CH Parry

WC Townsend

CWW Wynn

\section{$\underline{1850-1900}$}

A Bisset

EG Blackmore

EG Blackmore

EG Blackmore

EG Blackmore

R Bourke

R Gniest

JW Gordon

FW Maitland

TE May

TE May

TE May

GB Smith

W Stubbs

A Todd

1900-40

MV Clarke

H Graham

C Ilbert

WI Jennings

CH McIlwain

W Notestein

D Pasquet

AW Peel

AE Pollard

J Redlich

F Thompson
Law of Parliament in the present situation of Great Britain considered (c. 1789)

Privileges of Parliament (1792)

Parliamentary Papers (1660-1796, 3 vols) (1797)

Ancient method and manner of holding of Parliament in England (1768)

History of the Original Constitution of Parliament (1797)

Reports from the Committees of the House of Commons (1715-1801, 16 vols)

Brief Vindication of the rights of the British Legislature (1799)

Essays on Parliamentary Reform $(1859,1860,1872)$

Plan of Parliamentary Reform (1818)

Analytical Digested Index of Reported Cases in ...the High Court of Parliament (1825 with supplement)

Speeches of Lord Campbell at the Bar and in the House of Commons (1842)

Origin of the two Houses of Parliament $(1810)^{374}$

Law of Parliament as it relates to the Power and Privilege of the Commons House (1837)

Practice and Proceedings in Parliament (1825)

Modus Tenendi Parliamentum: An Ancient Treatise on the Mode of Holding the Parliament in

England (Eng \& Latin, 1846)

Precedents of Proceedings in the House of Commons (4 vols, $1^{\text {st }}$ ed, 1776; last ed 1818, 4 vols) $)^{376}$

Law and Usage of Parliament in Cases of Privilege and Contempt (1810)

Treatise on the Constitution of Parliament in the reign of Edward I (1818)

Privileges, Proceedings and Usage of Parliament $\left(1^{\text {st }}\right.$ ed, $1844 ; 25^{\text {th }}$ ed, 2019)

Parliamentary Writs and Writs of Military Summons (1827-34)

The Parliaments and Councils of England (1066-1688) (1839)

History of the House of Commons (1843-4)

Arguments on the Jurisdiction of the House of Commons to Commit in Cases of Breach of Privilege (1810)

History of the Struggle for Parliamentary Government (1877)

Decisions of Speaker Denison of the House of Commons 1857-72 (1881)

Decisions of Speaker Brand (1872-84, 4 vols)

Decisions of Speaker Peel (1887-1900, 3 vols)

Speakers Decisions (incorporating all the above in 2 vols) (1892-1900)

Parliamentary Precedents (1857)

History of the English Parliament (trans, 1886)

History of the English Parliament (trans $1^{\text {st }}$ ed, $1887 ; 4^{\text {th }}$ ed, 1895)

Parliamentary Manual (1885)

Memoranda de Parliamento $(1893)^{377}$

The Machinery of Parliamentary Legislation (1881)

The Constitutional History of England (1861-3, 2 vols, last ed 1912)

A Treatise upon the Law, Privileges, Proceedings and Usage of Parliament (1844)

History of the English Parliament (1892-4, 2 vols)

Constitutional History of England (1874-8, 3 vols)

Parliamentary Government in England (1867-9, 2 vols)

Medieval Representation and Consent $(1936)^{378}$

The Mother of Parliaments (1910)

Parliament, Its History, Constitution and Practice $\left(1^{\text {st }} \mathrm{ed}, 1911 ; 3^{\text {rd }} \mathrm{ed}, 1948\right)$

Parliament (1939)

Manual of the Practice of Parliament (1926)

High Court of Parliament and its Supremacy (1910)

The Winning of the Initiative by the House of Commons (1924)

History on the Origin of the House of Commons (trans, 1925)

Decisions on Points of Order, Rules of Debate \& General Practice of the House of Commons 1884-

1895 (1906)

Evolution of Parliament ( $1^{\text {st }}$ ed, $1920 ; 2^{\text {nd }}$ ed 1926)

The Procedure of the House of Commons (trans, 1908)

A Short History of Parliament 1295-1642 (1954)

\section{$\underline{1940-80}$}

\footnotetext{
${ }^{374}$ with an impartial statement of the privileges of the $\mathrm{HC}$ and of the liberty of the subject.

375 The best text is Pronay, see below (1980 -).

${ }^{376}$ Vol 1 (eds 1776, 1785, 1796, 1818), vol 2 (1781, 1785, 1796, 1818), vol 3 (1785, 1796, 1818), vol 4 (1818)

${ }^{377}$ Records of the Parliament holden at Westminster on February 28, 33 Edward I (1305).

${ }^{378}$ A study of early Parliaments in England and Ireland, with special reference to the Modus Tenendi Parliamentum.
} 
G Campion et al

G Campion

EA Forsey

S Gordon

S Lambert

GW Keeton

H Morrison

1980 -

PJ Aschenbrenner

R Blackburn/A Kennon

DH Coggins

D Dean

P Evans

J Goldsworthy

M Gordon

JH Hexter

JL Hiebert

WR McKay

D Natzler et al

D Oliver

N Pronay/J Taylor

H Robert

PDG Thomas

A Thrush/JP Ferris

MAJ Wheeler-Booth

K Wood

V Bogdanor
Parliament - A Survey (1952)

An Introduction to the Procedure of the House of Commons ( $1^{\text {st }}$ ed, 1929; $2^{\text {nd }}$ ed, 1947) $)^{379}$

Royal Power of Dissolution of Parliament in the British Commonwealth (Can, 1944)

Our Parliament $\left(1^{\text {st }}\right.$ ed, $1945 ; 4^{\text {th }}$ ed, 1952)

Bills and Acts: Legislative Procedure in $18^{\text {th }}$ century England (1971)

The Passing of Parliament $\left(1^{\text {st }}\right.$ ed, $1952 ; 2^{\text {nd }}$ ed, 1954)

Government and Parliament (1954)

Papers of John Hatsell, Clerk of the House of Commmons (2020)

Griffiths and Ryle on Parliament: Functions, Practice and Procedure ( $\left.2^{\text {nd }} \mathrm{ed}, 2003\right)$

Parliamentary Plan (2016)

Law Making and Society in late Elizabethan England. The Parliament of England 1584-1601 (2009)

Essays on the History of Parlimentary Procedure (2017)

Parliamentary Sovereignty (2010)

Parliamentary Sovereignty in the UK Constitution (2015)

Parliament and Liberty from the reign of Elizabeth to the English Civil War (1992)

Parliamentary Bill of Rights (2015)

Observations, Rules and Orders of the House of Commons: An Early Procedural Collection (1989)

Erskine May, Parliamentary Practice $\left(25^{\text {th }}\right.$ ed, 2019)

The Law and Parliament (1998)

Parliamentary Texts of the Later Middle Ages (1980) $)^{380}$

Parliamentary Practice (2008)

The House of Commons in the Eighteenth Century (1971)

The History of Parliament: The House of Commons 1604-1629 (2010)

Parliament: Functions, Practice and Procedure (1989)

Contempt of Parliament (2012)

The New British Constitution (2006)

Sweet and Maxwell, vol 1, also contains texts on the HL and the $\mathrm{HC}$ as well as on Protests, Reports and Elections. Vol 2 contains texts on Private Bills, Standing Orders, Elections and Constitutional Law. These are not listed here.

$\underline{\text { Date }}$

$\underline{\text { Act }}$

\section{APPENDIX B}

\section{Legislation applying to Parliament}

Bearing of Armour Act

Summons to Parliament

Privilege of Parliament Act

House of Lords Precedence Act

Privilege of Parliament Act

Crown and Parliament Recognition Act

Meeting of Parliament

Union with Scotland Act, arts 3 and 25

Union with England Act 1707, art 3

Succession to the Crown Act, s 29

Parliamentary Privilege Act

Parliamentary Privilege Act

Acts of Parliament (Commencement) Act

Meeting of Parliament Act

Meeting of Parliament Act

House of Commons (Disqualification) Act

Crown Debts Act

Acts of Parliament (Expiration) Act

Clerk of the Parliaments Act

Parliamentary Papers Act

Deputy Speaker Act

House of Commons Offices Act

Parliamentary Witnesses Act

Parliamentary Oaths Act

Prorogation Act

Parliamentary Returns Act

Meeting of Parliament Act

Parliamentary Witnesses Oaths Act

Bishoprics Act

Short Titles Act

Parliament Act $\underline{\text { No of Sections }}^{381}$

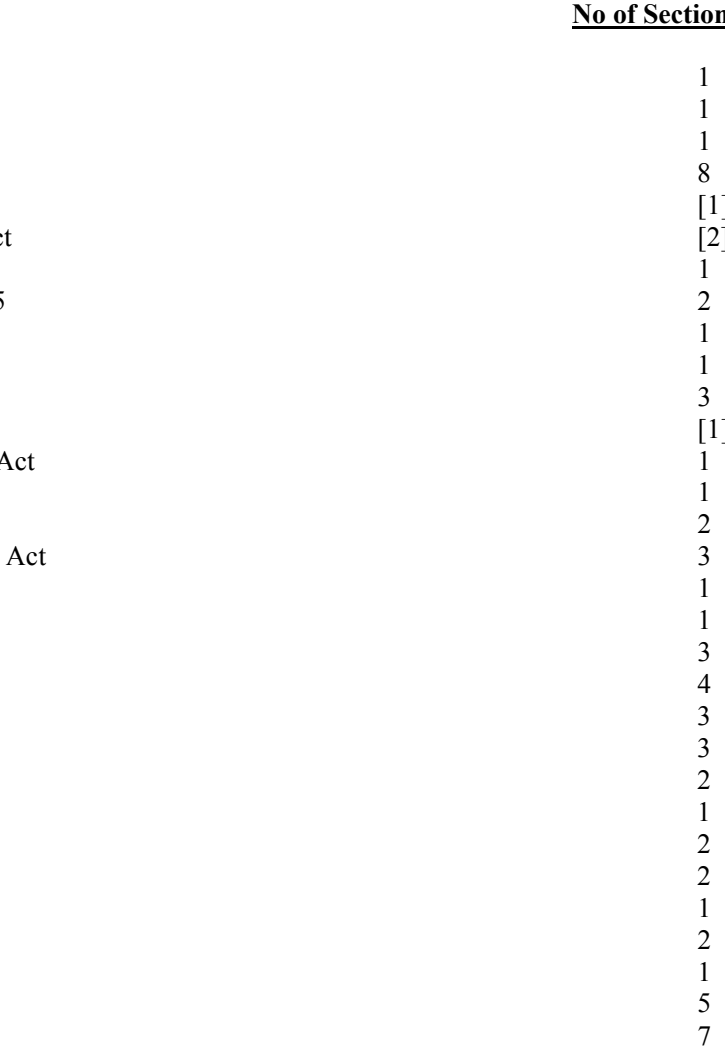

\footnotetext{
${ }^{379}$ See also Evans, n 4, p 119.

380 This contains a translation of Modus Tenendum Parliamentum (c. 1320) ('How to hold a Parliament').

${ }^{381}$ Excludes sections dealing with: short title, interpretation, consequential, transitional, amending or repealing other legislation.
} 


$\begin{array}{lll}1917 & \text { Chequers Estate Act } & 3 \\ 1918 & \text { Parliament (Qualification of Women) Act (otiose) } & 1 \\ 1927 & \text { Royal and Parliamentary Titles Act } & 1 \\ 1931 & \text { Statute of Westminster } & 9 \\ 1943 & \text { Parliament (Elections and Meeting) Act } & 1 \\ 1948 & \text { Laying of Documents before Parliament (Interpretation) Act } & 2 \\ 1949 & \text { Parliament Act } & 1 \\ 1958 & \text { Chequers Estate Act } & 3 \\ 1959 & \text { Chevening Estate Act } & 3 \\ 1962 & \text { Acts of Parliament Numbering and Citation Acts } & 1 \\ 1967 & \text { Parliamentary Commissioner Act } & 20 \\ 1967 & \text { Royal Assent Act } & 1 \\ 1975 & \text { House of Commons Disqualification Act } & 9 \\ 1975 & \text { Recess Elections Act } & 4 \\ 1976 & \text { Parliamentary and other Pensions and Salaries Act (spent) } & \\ 1978 & \text { House of Commons (Administration) Act } & \\ 1981 & \text { Parliamentary Commissioner (Consular Complaints) Act (amends) } \\ 1984 & \text { Parliamentary Pensions etc Act (amends) } & 5 \\ 1986 & \text { Parliamentary Constituencies Act } \\ 1987 & \text { Parliamentary Health Service Commissioners Act (amends) } & \\ 1987 & \text { Parliamentary and other Pensions Act (amends) } & \\ 1987 & \text { Chevening Estate Act } & 4 \\ 1992 & \text { Parliamentary Corporate Bodies Act } & 6 \\ 1994 & \text { Parliamentary Commissioner Act (amends) } & \\ 1999 & \text { House of Lords Act } & 33 \\ 2001 & \text { House of Commons (Removal of Clergy Disqualification) Act } & 1 \\ 2006 & \text { Parliamentary Costs Act } \\ 2007 & \text { Parliament (Joint Departments) Act } & 17 \\ 2009 & \text { Parliamentary Standards Act } & 5 \\ 2010 & \text { Constitutional Reform and Government Act } & 17 \\ 2011 & \text { Fixed Term Parliaments Act } & 6 \\ 2011 & \text { Parliamentary Voting and Constituencies Act } & 5 \\ 2014 & \text { House of Lords Reform Act } & 15 \\ 2015 & \text { Recall of MPs Act } & 6 \\ 2015 & \text { House of Commons Commission Act (amends) } & 21 \\ 2015 & \text { House of Lords (Expulsion and Suspension) Act } & \\ 2015 & \text { Lords Spiritual (Women) Act } & \\ & & \end{array}$

No of Acts (excluding spent and amending): $68^{382}$

\section{APPENDIX C}

An Act to consolidate and reform various matters relating to Parliament.

\section{$\underline{\text { Contents }}$}

\section{$\underline{\text { Parliament }}$}

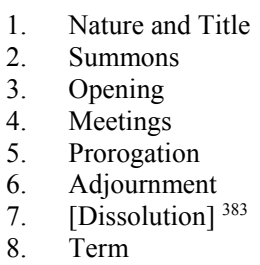

\section{Members and Peers of Parliament}

9. Members of Parliament (MPs)

10. Certain Privileges of MPs and Members of the House of Lords

11. Recall of MPs

12. Disqualification from the House of Commons

13. Disqualification from the House of Lords

14. Retirement from the House of Commons

15. Taxation of MPs and Members of the House of Lords

\section{Appointment of Ministers}

\section{Prime Minister}

\footnotetext{
${ }^{382}$ The Constitutional Reform Act 2005 is not mentioned since this material should be placed in a Courts Act, see 21(s)

${ }^{383}$ Whether this is needed will depend on any wording on a fixed term for Parliament.
} 
17. Ministers of the Crown

\section{Crown Prerogatives relating to Parliament}

18. Royal Assent

19. Abolition of Certain Crown Prerogatives

\section{Parliamentary Officials}

20. Speakers

21. Parliamentary Clerks

22. Clerk of the Court of Chancery

23. Other Parliamentary Officers

24. Parliamentary Commissioner

\section{Constituencies and Bodies}

25. Parliamentary Constituencies

26. House of Commons Commission

27. Parliamentary Corporate Bodies

28. Parliamentary Joint Departments

\section{Acts and Documentation}

29. Acts of Parliament

30. Laying documents before Parliament

31. Parliamentary Papers

\section{Other Parliamentary Matters}

32. Parliamentary Costs

33. Parliamentary Standards

34. Chequers and Chevening Estates

Parliamentary Practices and Procedures

35. Parliament Rule Book

36. Code of Conduct

37. Abolition of certain Parliamentary Practices and Procedures

38. Petitions

39. Contempts of Parliament

\section{Ratification of Treaties}

40. Treaties to be laid before Parliament before ratification

41. Extension of 21 day sitting period

42. Section 40 not to apply in exceptional cases

43. Section 40 not to apply to certain descriptions of treaties

44. Explanatory memoranda

45. Meaning of 'treaty' and 'ratification'

\section{General}

46. Communications

47. Supplementary

48. Erskine May, Parliamentary Practice

49. Palace of Westminster

50. Jurisdiction

51. Repeals

52. Interpretation

53. Application

Note: Wording in italics relates to the House of Lords. It is superfluous if the same is abolished.

\section{Nature and Title}

(1) Parliament means the:

(a) House of Commons; and the

(b) House of Lords,

in Parliament assembled. ${ }^{384}$

384 'House' (Anglo-Saxon, hus) refers to the chamber, 'in Parliament' refers to the building. 
(2) The UK shall be represented by one ${ }^{385}$ Parliament:

(a) which shall be known as, and styled,

(b) the 'Parliament of the United Kingdom of Great Britain and Northern Ireland',

(c) foreshortened to the 'UK Parliament'. 386

(3) The House of Lords in Parliament is abolished and sections 51 (Sch 1, pt 2) and 47(1) shall apply. ${ }^{387}$

2.

\section{$\underline{\text { Summons }}$}

(1) MP's, and members of the House of Lords, shall be summoned to Parliament by means of a proclamation. It shall state the:

(a) date when Parliament shall meet; and

(b) the place of meeting.

(2) In the case of an interregnum, ${ }^{388}$ the proclamation in (1) may be issued by the:

(a) Speaker (or former Speaker) of the House of Commons; or the

(b) Lord Speaker (or former Lord Speaker) of the House of Lords.

(3) Any Crown prerogative to summon Parliament is abolished.

(4) [An MP, or a member of the House of Lords, who, without lawful excuse, fails to attend Parliament on being summoned:

(a) shall incur the penalty of a daily fine,

(b) the level of which shall be set out in a SI,

(c) which SI shall, also, specify grounds constituting a lawful excuse. ${ }^{389}$

(5) The fine in (4) shall be imposed (as appropriate) by the:

(a) Speaker of the House of Commons; or the

(b) Lord Speaker of the House of Lords.

and it may be recovered by an action brought in the name of such, on behalf of Parliament, before the High Court.]

3.

\section{Opening}

(1) Parliament shall open on the date specified in the proclamation referred to in 2(1)

(a) which date shall not be less than 6 days

(b) from the date of issue of the proclamation.

(2) Parliament may be opened by the sovereign delivering an address in person. Or, the same being delivered by:

(a) a senior member of the royal family (or member of the royal household) the sovereign shall appoint; or, ${ }^{390}$

(c) in the case of an interregnum, by the person specified in 2(2)(a) or (b).

(3) The opening of Parliament pursuant to (2) is a ceremonial act. It shall not affect the obligation of Parliament to meet in (1).

4. Meetings

(1) In any one year Parliament shall meet, and sit, for a minimum period of [200-250] days.

(2) Parliament shall sit at Westminster save where:
(a) such is not physically possible; or
(b) the Civil Contingencies Act 2004 applies; or
(c) legislation provides otherwise.

5

\section{Prorogation}

(1) Parliament shall be prorogued by means of a proclamation. It shall state the date when Parliament shall reconvene:

(a) which date shall not be less than 6 days

\footnotetext{
${ }^{385}$ The words 'and the same' in the Union with Scotland Act 1706, art 3 (and the Union with England Act 1707, art 3) are superfluous.

${ }^{386}$ See Royal and Parliamentary Titles Act 1927, s 2(1).

${ }^{387}$ If the HL were to be abolished, this is the only phrase needed. For legislation that would be repealed if the HL were abolished, see Schedule 1 , Pt 2 .

${ }^{388}$ This deals with the position in 1660 and 1668 when there was no sovereign to summon Parliament, see 5(a).

${ }^{389}$ This deals with the Act of 1382 Act, see 3(f). However, in practice, the HC no longer imposes fines, since 1666, see $n$ 43. Thus, it may be sufficient to simply repeal the 1382 and to make no specific provision in an Act on this.

${ }^{390}$ The Lord Chamberlain is the most senior.
} 
(b) from the date of issue of the proclamation.

(2) Parliament may be prorogued in any one year a maximum number of:

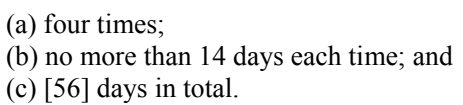

(3) Any prorogation of Parliament is subject to 4(1).

(4) Prorogation by the House of Commons shall automatically result in prorogation by the House of Lords.

(5) [Prorogation shall:

(a) end the existing session of Parliament; and

(b) have the effect that all bills of Parliament presently before Parliament shall lapse. ${ }^{391}$

(6) This section is subject to the earlier recall of Parliament pursuant to the Civil Contingencies Act 2004.

(7) Any Crown prerogative to prorogue Parliament is abolished. ${ }^{392}$

6.

\section{Adjournment}

(1) The House of Commons may vote to adjourn itself, which vote shall:
(a) state the date, and
(b) place for re-meeting.

(2) Adjournment (or recall from an adjournment) by the House of Commons shall automatically result in adjournment (or recall) by the House of Lords.

(3) The House of Commons may be recalled earlier than the date in (1) (that is, its recess may be foreshorten) if:

(a) the Speaker of the House of Commons is satisfied

(b) such would be in the public interest. ${ }^{393}$

(4) In the case of (3), the Speaker shall issue a notice to MP's [and members of the House of Lords]. It shall:

(a) state a date and place for re-assembling,

(b) which date shall not be less than [6] days from the date of issue of the notice.

If re-called, a new vote pursuant to (1) is required for any subsequent adjournment.

(5) The maximum period for which the House of Commons may be adjourned in any year is [165-115] days. ${ }^{394}$

(6) [Parliament may be recalled from an adjournment by means of a proclamation.] 395

(7) Any adjournment of Parliament is subject to 4(1).

(8) This section is subject to the earlier recall of Parliament pursuant to the Civil Contingencies Act 2004. ${ }^{396}$

(9) The following are abolished, any Crown prerogative to require:

(a) its consent to the adjournment of the House of Commons or the House of Lords $;^{397}$

(b) the House of Commons (or the House of Lords) to foreshorten, or lengthen, any adjournment. ${ }^{398}$

\section{Dissolution}

[(1) Parliament shall be dissolved by means of a proclamation. It shall indicate the date of dissolution.

(2) Any Crown prerogative to dissolve Parliament is abolished.] $]^{399}$

\footnotetext{
${ }^{391}$ As noted in $\mathbf{9}$, an alternative would be to make the result of prorogation the same as that of adjournment (i.e. bills continue).

${ }^{392}$ As noted in 9, the last time the sovereign prorogued Parliament in person was in 1854, see n 150.

${ }^{393}$ See 8(e).

${ }^{394}$ The precise number will reflect s $4(1)$.

${ }^{395}$ Whether this Crown prerogative should be retained is debatable, see $\mathbf{8}(\mathbf{b})$.

${ }^{396}$ May (in 2019), n 4, p 167.

${ }^{397}$ See 8.

${ }^{398}$ This is linked to (6).

${ }^{399}$ Dissolution of Parliament by the sovereign in person is obsolete, the last time may have been in 1818 , see 10. Provision as to dissolution depends on the provisions of $\mathrm{s} 8$.
} 
8. $\quad \underline{\text { Term }}$

(1) [This will set out the Fixed Term Parliaments Act 2011].

9. Members of Parliament (MPs)

(1) An MP must be a British citizen permanently domiciled in the UK in order to be an MP..$^{400}$

(2) [Any requirement of an MP to have to give an oath or affirmation in Parliament, is abolished]. ${ }^{401}$

\section{Certain Privileges of MPs and members of the House of Lords}

(1) The election of an MP must be freely made.

(2) Freedom of speech and debates, or proceedings, in Parliament shall not be challenged, or questioned, in:

(a) any court; or

(b) place outside Parliament.

(3) [No MP, or peer sitting in Parliament, shall be subject to arrest and/or imprisonment in respect of any civil:

(a) process; or

(b) legal proceedings,

while physically within the precincts of Parliament, save that such privilege shall not otherwise delay (a) or (b). $]^{402}$

(4) Neither the House of Commons nor the House of Lords have the power:

(a) by any vote or declaration,

(b) to create for themselves any new privileges,

(c) not warranted by the known laws and [customs] of Parliament. ${ }^{403}$

(5) The following are abolished, any privilege of:

(a) an MP, or a member of the House of Lords, to require the sovereign to grant an audience to the same; ${ }^{404}$

(b) the House of Commons to require the sovereign to favourably construe any House of Commons proceedings; ${ }^{405}$

(c) a member of the House of Lords to vote by proxy. ${ }^{406}$

\section{1. $\quad$ Recall of MPs}

[This will contain the Recall of MPs Act 2015].

12. Disqualification from the House of Commons

(1) (Disqualification). A person is disqualified from becoming an MP (or, if an MP, from continuing to be such) if:

(a) s 11 applies ${ }^{407}$ or if any of the following apply, the:

(b) Electoral Administration Act 2006, 17 (person under the age of 18); 408

(c) Insolvency Act 1986, ss 426 or 427 (bankruptcy); 409

\footnotetext{
${ }^{400}$ See Act of Settlement 1700, s 3, see 21(b)(vii).

${ }^{401}$ See GS McBain, Modernising the Law on Oaths and Affirmations [2020] Int. Law Research, vol 9, no 1, pp 1-55. Also, 20(r). Alternatively, this section can set out the form of oath required.

${ }^{402}$ See 16. Today, the grounds for arrest and/or imprisonment for a civil matter (especially debt) are very few. Thus, there would seem Little reason to preserve any privilege in respect of MPs going to fro from Parliament (and the 40 day period no longer exists). Therefore, any privilege (if at all) should relate to when inside the grounds of the same. However, it may be that even this is not required.

${ }^{403}$ See 19(f)(resolution of the HL of 1704 assented to by the HC). The word 'customs', today, is probably better put as 'practices'. See also Pike (in 1894), n 37, p 269 'There has been no power to create or develop privileges, except by Act of Parliament, since the year 1705...if, indeed, any such power existed.'

${ }^{404}$ See 17(a). This will not affect corporate access by either the HC or HL.

${ }^{405} \mathrm{Ibid}$. As previously noted, this is virtually meaningless since the sovereign is only permitted to consider the record of the HC. Also, this is (in reality) a courtesy in any case - not a privilege.

${ }^{406}$ See 3(e).

${ }^{407}$ This will re-state the Recall of MPs Act 2015, s 15 which states: '(effect of successful petition) '(1) If the petition officer notifies the Speaker under [s] 14(2)(b) that the recall petition was successful, the MP's seat becomes vacant on the giving of that notice. (2) That does not apply if the seat has already been vacated (whether by the MP's disqualification or death, or otherwise). (3) [ss] (1) is subject to regulations under [s] 18 about the questioning of the outcome of the recall petition.'

${ }^{408}$ See May (2019), n 4, p 30.

${ }^{409}$ Ibid, p 31.
} 
(d) Forfeiture Act 1870, s 2 (treason);

(e) Representation of the People Act 1981, s 1 (criminal offences); ${ }^{411}$

(f) Representation of the People Act 1983, ss 66 or 173 (election mis-practices); ${ }^{412}$

$$
\text { or if such a person is: }
$$

(g) not a British citizen permanently domiciled in the UK; ${ }^{413}$

(h) a member of the House of Lords or a lord spiritual; ${ }^{414}$

(i) the holder of any judicial office specified in Schedule 2, pt $1 ;^{415}$

(j) employed in the civil service of the Crown (whether in an established capacity or not, and whether for the whole or part of his time); ${ }^{416}$

(k) a member of:

(i) any of the regular armed forces of the Crown; ${ }^{417}$

(ii) any police force maintained by a local policing body or a police authority; ${ }^{418}$

(iii) the legislature of any country or territory outside the Commonwealth (other than Ireland); ${ }^{419}$

(1) the holder of any ministerial office described in Schedule 2, pt 2 or pt $3 ;^{.420}$

(m) [one who holds any office described in Schedule 2, pt 4 for any constituency specified in relation to that office in the second column of part 4$]$. $^{421}$

(n) a member of the:
(i) Scots Parliament;
(ii) National Assembly for Wales;
(iii) NI Assembly. ${ }^{422}$

(2) (Place of Profit etc). A person is not disqualified from membership of the House of Commons:

(a) by reason of his holding an office (or place of profit) under the Crown; or

(b) any other office (or place), and

(c) a person shall not be disqualified for appointment to (or for holding any) office (or place)

(d) by being a member of that house. ${ }^{423}$

(3) (Ministerial Offices). Not more than 95 persons being the holders of offices specified in Schedule 2, pt 2 (in this ss (3) referred to as ministerial offices) shall be entitled to sit and vote in the House of Commons at any one time. If at any time the number of members of the house who are holders of ministerial offices:

(a) exceeds the number entitled to sit and vote in the house under this ss,

(b) none

(c) except any who were both members of the house and holders of ministerial offices before the excess occurred;

(d) shall sit (or vote) therein until the number has been reduced, by death, resignation or otherwise,

(e) to the number entitled to sit and vote as aforesaid. ${ }^{424}$

A person holding a ministerial office is not disqualified by reason of any office held by him ex officio as the holder of that ministerial office. ${ }^{425}$

(4) (Reserve and Auxiliary Forces). Notwithstanding s (1)(k)(i) a person is not disqualified who:

(a) is an officer on the retired (or emergency) list of any of the regular armed forces of the Crown;

(b) holds an emergency commission in any of those forces;

(c) belongs to any reserve of officers of any of those forces;

(d) is a naval, army, marine or air force pensioner (or former soldier) who is recalled for service for which he is liable as such;

(e) is an Admiral of the Fleet, a Field Marshal or a Marshal of the Royal Air Force (if he does not for the time being hold an appointment in the naval, military or air force service of the Crown); or

\footnotetext{
${ }^{410}$ Ibid, p 31

${ }^{411}$ Ibid, pp 31-2.

412 Ibid, pp 32-3. Reference is made to s 66 since it would seem appropriate such offences also be included.

${ }^{413}$ Ibid, pp 29-30 (reducing the scope of the same, see 21(b)(vii).

${ }^{414}$ Ibid, p 30. See also House of Commons Disqualification Act 1975, s 1(za) (lord spiritual)

${ }^{415}$ Ibid, p 35-6. See also n 288 which lists them. Also, House of Commons Disqualification Act 1975 (the '1975 Act'), s 1.

${ }^{416}$ Ibid, p 34. See also 1975 Act, s 1.

${ }^{417}$ Ibid. See also 1975 Act, s 1.

${ }^{418}$ Ibid, p 35. See also 1975 Act, s 1.

${ }^{419}$ Ibid. See also 1975 Act, s 1.

${ }^{420}$ See 1975 Act, Schedule. Pt 2 refers to ministerial bodies, pt 3 to bodies of which all members are disqualified.

${ }^{421}$ This re-states the 1975 Act, s 1(2). A Crown Act, n 1, p 91 (sch 7) proposes these offices (sinecures) be abolished.

${ }^{422}$ See House of Commons (Disqualification) Act 1801, see 21(b)(iv).

${ }^{423}$ See also 1975 Act, s 1(4).

${ }^{424}$ Ibid, s 1.

${ }^{425}$ See also 1975 A ct, s 2.
} 
(f) is a member of the Royal Observer Corp (unless employed as such for the whole of his time). ${ }^{426}$

(5) (Effects of disqualification and provision for Relief).

(a) Subject to any order made by the House of Commons under this s 12 - (i) if any person disqualified by this $\mathrm{s} 12$ for membership of that house (or for membership for a particular constituency) is elected as a member of that house (or as a member for that constituency, as the case may be) his election shall be void; and (ii) if any person being a member of that house becomes disqualified by this section for membership (or for membership for the constituency for which he is sitting) his seat shall be vacated.

(b) If, in a case falling (or alleged to fall) within (a), if it appears to the House of Commons that the grounds of disqualification or alleged disqualification under this s 12 which subsisted (or arose) at the material time have been removed, and that it is otherwise proper so to do, that house may by order direct that any such disqualification incurred on those grounds at that time shall be disregarded for the purposes of this s 12 .

(c) No order under (b) shall affect the proceedings on any election petition (or any determination of an election Court) and this ss shall have effect subject to the provisions of s 144(7) of the Representation of the People Act 1983 (making of an order by the House of Commons when informed of a certificate and any report of an election court).

(d) In any case where, by virtue of the [Recess Elections Act 1975] $]^{427}$, the Speaker of the House of Commons would be required to issue during a recess of that house a warrant for a new writ for election of a member, in the room of a member becoming disqualified by this Act, he may, if it appears to him that an opportunity should be given to that house to consider the making of an order under (b), defer the issue of his warrant pending the determination of that house. . $^{428}$

(6) (Jurisdiction of Privy Council as to disqualification). [It would seem better for the High Court to have jurisdiction]. ${ }^{429}$

(7) (Relaxation of obligation to accept office). No person being a member of the House of Commons (or for the time being nominated as a candidate for election to that house) shall be required to accept any office or place by virtue of which he would be disqualified by this s 12 for for membership:

(a) of that house; or

(b) of that house for the constituency for which he is sitting (or is a candidate).

This ss does not affect any obligation to serve in the armed forces of the Crown (whether imposed by an enactment or Otherwise). ${ }^{430}$

\section{Disqualification from the House of Lords}

[This will make reference to the Act of Settlement 1700, a Standing Order of 22 May 1685 (no Lord under 21 shall sit), Insolvency Act 1986, ss 426A and 427, Forfeiture Act 1870, Constitutional Reform Act 2005, s 137, House of Lords Reform Act 2014, House of Lords Reform Act 2014 and House of Lords (Expulsion and Suspension) Act 2015]. ${ }^{431}$

\section{4. $\quad$ Retirement from the House of Commons and Vacancies}

(1) (Retirement/Resignation). An MP may retire (or resign) from Parliament by giving notice in writing to the Speaker of the House of Commons:

(a) which notice shall take effect 6 days from;

(b) the date of its receipt by the same. ${ }^{432}$

(2) In the case of (1), the seat shall become vacant. ${ }^{433}$

(3) (Issue of Warrants by Speaker for making out Writs). During any recess of the House of Commons, whether by prorogation or adjournment, it shall be the duty of the Speaker (subject to the provisions of this Act) on receipt of a certificate of vacancy to issue his warrant to the Clerk of the Crown in Chancery to make out a new writ for electing a member of the house in place of a member whose seat has become vacant - (a) because he has died or become disqualified as a peer for membership of the House of Commons, either during the recess or before it; (b) because he has accepted a disqualifying office during the recess;

426 Ibid, s 3.

${ }^{427}$ The provisions of this will be stated in $\mathrm{s} 14$ below.

${ }^{428}$ See 1975 Act, s 6.

${ }^{429}$ Ibid, s 7. See n 279.

${ }^{430}$ See 1975 Act, s 8.

${ }^{431}$ If the HL is abolished, this section will not be required. See also May (in 2019), n 4, pp 41-4.

${ }^{432}$ The intention of this is to replace the 1975 Act, s 4 (Stewardship of Chiltern Hundreds, etc.) 'For the purposes of the provisions of this Act relating to the vacation of the seat of a member of the $[\mathrm{HC}]$ who becomes disqualified by this Act for membership of that House, the office of steward or bailiff of [HM's] three Chiltern Hundreds of Stoke, Desborough and Burnham, or of the Manor of Northstead, shall be treated as included among the offices described in Part [3] of Schedule 1 to this Act.' See also May (2019), n 4, pp 37-8.

${ }^{433}$ See May (2019), n 4, p 38. 
or (c) because of his bankruptcy; ${ }^{434}\left[\right.$ because (1) applies]. ${ }^{435}$

(4) (Restriction on Speaker's Powers). (1) The Speaker shall cause notice of his receipt of a certificate of vacancy to be inserted in the London Gazette. (2) The Speaker shall not issue a warrant under (3) until 6 days after the insertion of the notice. (3) The Speaker shall not issue such a warrant unless he has received the certificate of vacancy so long before the date of the next meeting of the House of Commons for the despatch of business that the writ for the by-election may be issued before that date. (4) Except where a seat has become vacant because of a member's bankruptcy, the Speaker shall not issue such a warrant - (a) unless the return of the writ for the election of the member whose seat has become vacant has been brought into the office of the Clerk of the Crown in Chancery 15 days at least before the end of the last sitting of the House of Commons before the Speaker's receipt of the certificate of vacancy; or (b) if a petition against the election of the member whose seat has become vacant was pending when Parliament was prorogued or the House of Commons was adjourned. ${ }^{436}$

(5) (Acceptance of Office) (1) A member of the House of Commons who accepts a disqualifying office shall forthwith give written notice of his acceptance to the Speaker; and the notice may be given by signing a certificate of vacancy. (2) Where a seat becomes vacant on a member's acceptance of a disqualifying office, the Speaker shall not issue a warrant under (3) above unless the certificate of vacancy is accompanied by a copy of the issue of the London, Edinburgh or Belfast Gazette in which the Member's appointment to that office was gazetted.

\section{Taxation of MPs and Members of the House of Lords}

[This will contain the Constitutional Reform and Governance Act 2010, s 41].

16. Prime Minister

(1) The sovereign shall appoint as PM the leader of the political party that commands an overall majority of MPs in the House of Commons.

(2) If a PM resigns while (1) prevails, the sovereign shall appoint as PM the person elected by his political party to be his successor.

(3) If (1) does not apply (that is, the case of a 'hung' Parliament), the incumbent PM shall remain in office until he tenders his resignation (and that of his government) to the sovereign.

(4) The incumbent PM may delay tendering his resignation (and that of his government) in (3) until the first meeting of a new session of Parliament, in order for him to determine whether his political party can command an overall majority of MP's in the House of Commons.

(5) Where a PM, pursuant to (4):

(a) cannot command an overall majority of MP's in the House of Commons; or

(b) his government suffers defeat [on the address of the sovereign $]^{437}$ at the first meeting of a new session of Parliament,

the sovereign shall appoint as PM the leader of the largest opposition party in the House of Commons.

(6) A PM, even if entitled to sit in the House of Lords, shall sit in the House of Commons while PM.

17.

\section{Ministers of the Crown}

(1) The PM shall:

(a) appoint;

(b) dismiss; or

(c) accept the resignation of;

any minister of the Crown pursuant to a formal letter issued by the [Cabinet Office] signed by the PM

18.

\section{Royal Assent}

(1) The sovereign may not refuse assent to a Bill of Parliament otherwise validly passed. ${ }^{438}$

(2) Acts shall take effect in accordance with section 29(1).

(3) [Add Royal Assent Act 1967, s 1]

\footnotetext{
${ }^{434}$ This re-states the Recess Elections Act 1975, s 1.

${ }^{435}$ That is, the MP has given notice of his wish to retire/resign. Consideration should be given to abolishing writs (and warrants and publication in the Gazette) and, instead, relying on an (electronic) proclamation. It would save time, money, administration and be more easily understood.

${ }^{436}$ Ibid, s 2.

${ }^{437}$ Given s 3(3), this wording may not be appropriate

${ }^{438} \mathrm{Cf}$. It could also be, alternatively, stated: 'Any requirement of royal assent to any bill of Parliament is abolished.'
} 
(1) The following Crown prerogatives are abolished, the prerogative of the sovereign (including the Crown in the case of (i)) to:

(a) appoint any officer of the House of Commons or the House of Lords (including any sarjeant-at-arms or Black Rod);

(b) appoint Lords Commissioners;

(c) confirm the privileges of the House of Commons;

(d) communicate with Parliament orally, save when attending Parliament in person;

(e) recommend, or consent, to any bill of Parliament (or the content thereof);

(f) add to the members of the House of Commons;

(g) add to the members of the House of Lords by personal decision; ${ }^{439}$

(h) licence the use of a proxy in the House of Lords;

(i) originate any Act of Grace;

(j) fine (amerce) a member of the House of Commons or the House of Lords for non-attendance at Parliament subsequent to a summons.

(2) Any Crown prerogative in (1)(e), franchised to the Duke of Cornwall (or the Duchy of Cornwall), is abolished.

\section{0. $\quad$ Speakers}

(1) The Speaker of the House of Commons shall be appointed, and dismissed, by vote of the House of Commons.

(2) The Lord Speaker of the House of Lords shall be appointed, and dismissed, by vote of the House of Lords.

(3) It shall be the duty of the Speaker of the House of Commons, within a convenient time after taking office, by instrument in writing under his hand and seal, to appoint not more than 7 nor less than 3 members of the House of Commons to exercise the powers given to the speake at any time when there is no speaker or the speaker is out of the UK; and if the number of persons appointed is reduced to less than 3 , he may appoint one or more further members, and,

(a) an appointment shall remain in force until the dissolution of the Parliament in which it is made.

(b) an appointment shall be entered in the journals of the house and be published once in the London Gazette, and the instrument of appointment shall be preserved by the Clerk of the House of Commons, [ and a duplicate filed in the office of the Clerk of the Crown in Chancery]. ${ }^{440}$

(c) the powers of the speaker may be exercised by any one of the members appointed under this [ss], but when notice of the issue of a warrant is brought to the publisher of the Gazette and is signed by a member so appointed, the publisher shall give a receipt for it, specifying the day and hour when it was received, and if more than one notice is brought to him relevant to the same election, he shall insert in the Gazette only the notice first received. ${ }^{44}$

(4) If, at any time during a session of Parliament, the Speaker of the House of Commons or the House of Lords shall be temporarily absent from the house, and a deputy speaker shall thereupon perform the duties and exercise the authority of the speaker, pursuant to the standing orders (or other order or resolution of that house) and:

(a) every act done and proceeding taken in or by the house pursuant to any Act shall be as valid and effectual as if the Speaker himself were in the chair; and

(b) every act done, and warrant, order, certificate, notice, or other document issued, signed, or published, in relation to any proceedings of the house by such deputy speaker, shall have the same effect and validity as if the same had been done, issued, signed, or published by the speaker for the time being. ${ }^{42}$

(5) Any Crown prerogative to appoint (or consent to) the appointment of (1) or (2) is abolished. ${ }^{443}$

\section{Parliamentary Clerks ${ }^{444}$}

(1) The Clerk of the House of Commons shall be appointed, and dismissed, by vote of the House of Commons.

(2) The Clerk of the Parliaments shall be appointed, and dismissed, by vote of the House of Lords.

(3) Any deputy or assistant clerk to the Clerk of the House of Commons shall be appointed, and dismissed, by the House of Commons Commission.

(4) Any deputy or assistant clerk to the Clerk of Parliaments, including the Clerk Assistant, shall be appointed, and dismissed, by

${ }^{439}$ See 3(g).

${ }^{440}$ Is such still necessary?

441 This replicates the wording in the Recess Election Act 1970, s 4.

442 This replicates the Deputy Speaker Act 1855, s 1 but also extends the wording to the HL.

${ }^{443}$ See 3(a).

${ }^{444}$ This reflects the Clerk of the Parliaments Act 1824 and the House of Commons Offices Act 1856, as modernised, see 19(e). For the unsatisfactory process re the appointment of clerks in the past, see Evans, $\mathrm{n} 4$, ch 1 
the House of Lords Commission. ${ }^{445}$

(5) Any Crown prerogative to appoint, or consent to, the appointment of any of (1)-(4) is abolished. ${ }^{446}$

\section{Clerk of the Court of Chancery}

(1) The Clerk of the Court of Chancery shall be appointed by the Clerk of the Parliaments:

(a) which appointment shall be confirmed by

(b) the Speaker of the House of Commons and the Lord Speaker of the House of Lords. ${ }^{447}$

\section{Other Parliamentary Officers}

(1) Save for those Parliamentary officers referred to in ss 20-22, all other Parliamentary officers shall be appointed and dismissed by the:

(a) House of Commons Commission, in the case of those employed in the House of Commons (including any sarjeant at arms); and

(b) the Clerk of the Parliaments, in the case of those employed in the House of Lords (including Black Rod).

(2) Any Crown prerogative to appoint (or consent to) the appointment of any in (1) is abolished. ${ }^{448}$

\section{Parliamentary Commissioner}

[This will contain the Parliamentary Commissioner Act 1967].

25. Parliamentary Constituencies

[This will contain Parliamentary Constituencies Act 1986 and the Parliamentary Voting and Constituencies Act 2011].

\section{House of Commons Commission}

[This will contain the House of Commons (Administration) Act 1978].

\section{Parliamentary Corporate Bodies}

[This will contain the Parliamentary Corporate Bodies Act 1992].

\section{Parliament Joint Departments}

[This will contain the Parliament (Joint Departments) Act 2007].

\section{Acts of Parliament}

(1) Commencement. ${ }^{449}$ The clerk of the Parliaments shall endorse (in English) on every Act which shall pass, immediately after the title of such Act, the:

(a) day, month and year when the same shall have passed and shall have received the royal assent, ${ }^{450}$ and

(b) such endorsement shall be taken to be part of such Act; and

(c) the Act shall take effect from $12 \mathrm{pm}$ on the date so endorsed; or

(d) on a failure to endorse, when the same should have so been endorsed. ${ }^{451}$

(2) [Evidence of the Copy of Acts of England and Great Britain prior to 1800 in Northern Irish Courts. The copy of the Acts of the kingdom of England and of the kingdom of Great Britain since the union with Scotland in 1706, printed and published by the printer duly authorized to print and publish the same by the sovereign at that date (or by any of his royal predecessors) shall be received as:

(a) conclusive evidence of the several Acts made and enacted prior to the union of the kingdoms of Great Britain and Ireland by the Parliaments of England and Great Britain respectively,

\footnotetext{
${ }^{445}$ At present, the Clerk Assistant and Reading Clerk are appointed by the Lord Speaker, subsject to the approbation of the HL and they cannot be suspended or removed without an order the HL, May (in 2019), n 4, p 124.

${ }^{446}$ See 3(e).

${ }^{447}$ Alternatively, perhaps, this should be by vote of the HC. At present he (or she) is appointed by the Crown, May (2019), n 4, p 127.

${ }^{448}$ See 3(e). Thus, the clerk assistant and the sarjeant at arms in the HC (and Black Rod in the HL) will no longer be appointed by the Crown. And the Speaker of the HC shall no longer appoint his staff.

${ }^{449}$ See Acts of Parliament (Commencement) Act 1793, see 21(k).

${ }^{450}$ If the royal assent (see s 18) is abolished, when an Act takes effect should be clarified

${ }^{451}$ These will apply if the royal assent is abolished.
} 
(b) in all suits, actions, or prosecutions respectively commenced, instituted, or carried on (or to be commenced, instituted, or carried on) in any court of civil or criminal jurisdiction in NI. ${ }^{452}$

(3) Evidence of the Copy of Irish Acts prior to 1800 in British Courts. The copy of the Acts of the kingdom of England, and of the kingdom of Great Britain since the union with Ireland in 1800 printed and published by the printer duly authorized to print and publish the same by the sovereign at that date (or by any of his royal predecessors) shall be received as:

(a) conclusive evidence of the several Acts made and enacted by the Parliament of Ireland prior to the union of the kingdoms of Great Britain and Ireland, in all suits, actions, or prosecutions respectively,

(b) commenced, instituted, or carried on (or to be commenced, instituted, or carried on) in any court of civil or criminal jurisdiction in Great Britain. ${ }^{453}$ ]

[(4) Expiration. Where any bill may have been or shall be introduced into this present or any future session of Parliament for the continuance of any Act which would expire in such sessions, and such Act shall have expired before the bill for continuing the same shall have received the royal assent, such continuing Act:

(a) shall be deemed to have taken effect from the date of the expiration of the Act intended to be continued as fully and effectually, to all intents and purposes

(b) as if such continuing Act had actually passed before the expiration of such Act (except that it shall be otherwise especially provided in such continuing Act)

(c) provided nevertheless, that nothing herein contained shall extend or be construed to extend to effect any person(s) with any punishment, penalty, or forfeiture whatsoever, by reason of anything done (or omitted to be done) by any such person(s) contrary to the provisions of the Act so continued, between the expiration of the same and the date at which the Act continuing the same may have received (or shall receive) the royal assent. $]^{454}$

(5) Short Title. Any short titles in the Short Titles Act 1896 in respect of Acts still extant are hereby preserved. ${ }^{455}$

(6) Number and Citation. The chapter numbers assigned to Acts after 1963 shall be assigned by:

(a) reference to the calendar year, and not the session, in which they are passed; and

(b) any such Act may, in any Act, instrument or document, be cited accordingly. ${ }^{456}$

\section{Laving Documents before Parliament}

[This will contain the Laying of Documents before (Interpretation) Act 1948].

\section{Parliamentary Papers}

[This will contain the Parliamentary Papers Act 1840 and the Parliamentary Returns Act 1869].

\section{Parliamentary Costs}

[This will contain the Parliamentary Costs Act 2006].

33. Parliamentary Standards

[This will contain the Parliamentary Standards Act 2009].

\section{Chequers and Chevening Estates}

[This will contain the Chequers Acts 1917 and 1958 and the Chevening Estate Acts 1959 and 1987].

\section{5. $\quad$ Parliament Rule Book}

(1) All Parliamentary practices and procedures shall be consolidated into a Parliament Rule Book ('PRB').

(2) The PRB shall be:

(a) set out in as user-friendly a manner as possible,

(b) comprehensive

(c) updated every 3 years, at least.

(3) A free copy of the PRB shall be:

\footnotetext{
${ }^{452}$ See Crown Debts Act 1801, see 21(k). It would seem easier to amend the Evidence Act 1845, s 3 to cover this (simplying the language as well). See also May (2019), n 4, p 148.

453 Ibid.

${ }^{454}$ See Acts of Parliament (Expiration) Act 1808, see 21(k). Is this provision still necessary?

${ }^{455}$ See Short Titles Act 1896, see 21(k).

${ }^{456}$ See Acts of Parliament Numbering and Citation Act 1962, see 21(k).
} 
(a) given to all MP's and members of the House of Lords;

(b) provided online.

(4) The PRB shall cover, inter alia, the following procedures and processes:

- $\quad$ Sittings (of the House of Commons and the House of Lords and in Westminster Hall);

- Order of Business;

- Motions;

- Questions;

- Decisions;

- Debate (including manner of speaking, time and length of speeches, content of speeches, behaviour and enforcement of order by the chair);

- Divisions;

- Passage of bills;

- $\quad$ Passage of statutory instruments (i.e. delegated legislation);

- Protests;

- Personal Interests;

- $\quad$ Committees of the whole House;

- Select Committees;

- General and Grand Committees;

- Witnesses;

- Communications between the HL and the HC;

- Communications between the Crown and Parliament (including Addresses by Parliament)

- Petitions;

- Other matters.

\section{Code of Conduct}

(1) Parliament shall issue a Parliament Code of Conduct ('PCC') to regulate the conduct of MPs and members of the House of Lords.

(2) The PCC shall be:

(a) set out in as user-friendly a manner as possible;

(b) comprehensive (incorporating any code of behaviour); ${ }^{457}$

(c) updated every 3 years, at least.

(3) A free copy of the PCC shall be:

(a) given to all MP's and members of the House of Lords;

(b) provided online.

37. $\quad$ Abolition of certain Parliamentary Practices and Procedures

(1) The following Parliamentary practices and procedures shall be abolished:

(a) the reading of a bill pro forma after the address by the sovereign on the opening of Parliament;

(b) any address by Parliament to the sovereign in reply to the address in (a);

(c) any address by Parliament in reply to a message from the sovereign;

(d) the use of parchment (vellum) to record any Parliamentary paper;

(e) the making of any written protest by a member of the House of Lords.

38. $\quad$ Petitions

(1) It is the right of the subject to petition the sovereign.

(2) All petitions sent to:

(a) the Crown (including the sovereign); or

(b) Parliament (including to the House of Commons and the House of Lords, whether jointly or separately); or

(c) the government (including any Minister of the Crown or any Ministry)

shall be sent (or re-directed) to the Petitions Committee in Parliament (the 'PCIP').

(3) All petitions shall be made online to the PCIP and not in hard copy, to expedite processing.

(4) There is no obligation on the PCIP:

(a) to reply to any petition; or to

\footnotetext{
${ }^{457}$ May (2019), n 4, p 136 'In 2018 the [HC] endorsed a new Behaviour Code governing the conduct of everyone working in or visiting the parliamentary estate.'
} 
(b) publish the same (or any correspondence); and

(c) any correspondence by the PCIP may be made online, to reduce cost.

\section{Contempts of Parliament}

(1) All contempts of Parliament and the fines in respect thereof:

(a) shall be set out in a SI,

(b) which shall be amended from time to time.

[(2) The fines in (1) may be recovered by an action brought in the name of the:

(a) Speaker of the House of Commons; or the

(b) Lord Speaker of the House of Lords,

(as appropriate) on behalf of Parliament, before the High Court.] ${ }^{458}$

(3) The High Court shall have jurisdiction to interpret the SI in (1).

\section{0-5. Ratification of Treaties}

[This will contain ss 20-5 of the Constitutional Reform and Governance Act 2010].

\section{Communications}

(1) All proclamations in this Act may be in electronic form.

(2) All communications between the sovereign and Parliament shall:

(a) be in writing, save in the case of $\mathrm{s} 3(2)$;

(b) not require the great seal, save where legislation requires.

(3) All communications between the House of Commons and the House of Lords shall be:

(a) in writing, save where the same vote otherwise;

(b) may be in electronic form.

47. Supplementary

(1) Any legislation or common law matter attendant on, or consequential to, s 1(3) may be:

by a SI.
(a) repealed;
(b) abolished; or
(c) amended,

(2) If at any time it is resolved by the House of Commons that Schedule 2 to this Act be amended (whether by the addition or omission of any office or the removal of any office from one Part of the Schedule to another, or by altering the description of any office specified therein) HM:

(a) may by Order in Council amend that Schedule accordingly, and

(b) a copy of this Act as from time to time amended by Order in Council under this ss (or by or under any other enactment),

(c) shall be prepared and certified by the Clerk of the Parliaments, and

(d) deposited with the rolls of Parliament, and

(e) all copies of this Act thereafter to be printed by HM's printer shall be printed in accordance with the copy so certified. $^{459}$

(3) The Colonial Laws Validity Act 1865 and the Colonial Courts of Admiralty Act 1890 shall not apply to Australia, Canada, Ireland or New Zealand. ${ }^{460}$

(4) All legislation relating to Parliamentary elections shall be consolidated into one Act. ${ }^{461}$

\section{8. $\quad$ Erskine May - Parliamentary Practice}

(1) Any future edition of the work Erskine May, Parliamentary Practice, shall be:

(a) put online on a Parliament website;

(b) accessible by the general public without charge

${ }^{458}$ It may be that some other sanction should be specified in the SI, see $\mathrm{n} 43$.

${ }^{459}$ This replicates the House of Commons Disqualification Act 1975, s 5.

${ }^{460}$ This simply enables the Statute of Westminster 1931 to be repealed in its entirety, see 21(u).

${ }^{461}$ Such would consolidate some 10 Acts. The same could then be added to this Parliament Act. 
(2) Any version in (1) is without prejudice to the issue of a hardcopy version, for which a charge may be made.

49.

\section{Palace of Westminster}

(1) Parliament shall allocate money to:

(a) acquire any title (whether freehold or leasehold)

(b) in the palace of Westminster; and

(c) hold the same on behalf of the nation.

(2) The physical ambits of (1) shall be:

(a) set out in a SI as amended from time to time; and

(b) title to the palace of Westminster shall be registered in the name of Parliament.

(3) Any title (whether freehold or leasehold) held by the Crown or the Crown Estate in the palace of Westminster, hereby passes to Parliament, without payment.

(4) Any control held by the Crown or the Crown Estate in the palace of Westminster, hereby passes to Parliament without payment, including the following:

(a) Westminster Hall;

(b) HM's robing room (including the staircase and ante-room adjoining);

(c) Royal Gallery;

(d) Chapel of St Mary Undercroft,

without prejudice to Parliament according the sovereign access to (a)-(d) for any state occasion.

\section{Jurisdiction}

(1) The High Court shall have jurisdiction over any legal proceedings brought pursuant to this Act.

\section{1. $\quad \underline{\text { Repeals }}$}

(1) The legislation in Schedule 1 is repealed, or amended, as described.

\section{Interpretation}

(1) In this Act:

(a) 'Act' refers to an Act of Parliament;

(b) ' $H M$ ' refers to Her Majesty;

(c) ' $M P$ ' refers to a member of the UK Parliament;

(d) 'Parliamentary papers' means all documents issued to the public, including: (i) the Journals of the House of Commons and the House of Lords; ( ii) Hansard; ${ }^{462}$ (iii) Parliamentary returns; (iv) command papers; (v) Act papers;

(e) ' $N I$ ' means Northern Ireland;

(f) ' $P M$ ' means the Prime Minister;

(g) ' $s$ ' means a section and ' $s s$ ' means sub-section;

(h) 'SI' means a statutory instrument;

(i) ' $U K$ ' means Great Britain and NI.

(2) For the purposes of $\mathrm{s} 12$ :

'civil service of the Crown' includes the civil service of NI, HM's Diplomatic Service and HM's

Overseas Civil Service;

'police authority' means any police authority within the meaning of the Police Act 1996, the Scottish Police

Authority, or the NI Policing Board;

'member' in relation to a police force means a person employed as a full-time constable;

'Minister of State' means a member of HM's Government in the UK who neither has charge of any public department nor holds any other of the offices specified in Schedule [2] or any office in respect of which a salary is payable out of money provided by Parliament under s 3(1)(b) of the Ministerial and other Salaries Act 1975;

'Parliamentary Secretary' includes a person holding Ministerial office (however called) as assistant to a member of HM's Government in the UK, but not having departmental responsibilities;

\footnotetext{
${ }^{462}$ This is intended to refer to the Official Reports of Parliament from 1803, see May (2019), n 4, pp 150-2
} 
'regular armed forces of the Crown' means the Royal Navy, the Royal Marines, the regular army (as defined by s 374 of the Armed Forces Act 2006) or the Royal Air Force. ${ }^{463}$

(3) For the purposes of s 14:

'certificate of vacancy' means - (a) where the seat has become vacant because an MP has died, become disqualified as a peer for membership of the House of Commons or accepted a disqualifying office, a certificate under the hands of 2 members of the House of Commons in the form set out in Schedule 3 to this Act, or to the like effect; and (b) where the seat has become vacant because of an MP's bankruptcy, a certificate under [s] 427(6)(a) of the Insolvency Act 1986;

'disqualifying office' means any office, [other than the office of steward or bailiff of HM's 3 Chiltern Hundreds of Stoke, Desborough and Burnham or of the Manor of Northstead,] which disqualifies its holder for membership of the House of Commons.

(4) In this Act, reference to the:

(a) 'sovereign' refers to the sovereign in person (that is, in the body natural);

(b) 'Crown' refers to the sovereign as well as the same in the body politic, unless otherwise provided.

\section{Application}

(1) This Act applies to Scotland and NI.

\section{$\underline{\text { Schedule 1, Part } 1}$}

Bearing of Armour Act 1313

Summons to Parliament 1382

Privilege of Parliament Act 1512

Privilege of Parliament Act 1603

Bill of Rights 1688

That it is the right of the subjects to petition the king and all commitments and prosecutions for such petitioning are illegal....That election of members of Parliament ought to be free.... That the freedom of speech and debates or proceedings in Parliament ought not to be impeached or questioned in any court or place out of Parliaament...And that for redress of all grievances and for the amending strengthening and preserveing of the laws Parliaaments ought to be held frequently.

Crown and Parliament Recognition Act 1689

Meeting of Parliament 1694

Act of Settlement 1700

In s 3(3) delete the words 'capable to be... a member of either

Union with Scotland Act 1706

Union with England Act 1707

Succession of the Crown Act 1707

house of Parliament'

repeal article 3

Parliamentary Privilege Act 1737

repeal article 3

Parliamentary Privilege Act 1770

Acts of Parliament (Commencement) Act 1793

Meeting of Parliament Act 1797

Meeting of Parliament Act 1799

House of Commons (Disqualifications) Act 1801

Crown Debts Act 1801

Acts of Parliament (Expiration) Act 1808

Clerk of the Parliaments Act 1824

Parliamentary Papers Act 1840

Deputy Speaker Act 1855

House of Commons Offices Act 1856

Parliamentary Witnesses Act 1858

Parliamentary Oaths Act 1866

Prorogation Act 1867

Parliamentary Returns Act 1869

Meeting of Parliament Act 1870

Parliamentary Witnesses Oaths Act 1871

Short Titles Act 1896

Chequers Estate Act 1917

Parliament (Qualification of Women) Act 1918

Royal and Parliamentary Titles Act 1927

Statute of Westminster 1931

Parliament (Elections and Meeting) Act 1943

Laying of Documents before Parliament (Interpretation) Act 1948

${ }^{463}$ See 1975 Act, ss 1(3) and 9. 
Chequers Estate Act 1958

Chevening Estate Act 1959

Acts of Parliament Numbering and Citation Acts 1962

Parliamentary Commissioner Act 1967

Royal Assent Act 1967

Recess Elections Act 1975

House of Commons Disqualification Act 1975

Parliamentary and other Pensions and Salaries Act 1976

House of Commons (Administration) Act 1978

Parliamentary Commissioner (Consular Complaints) Act 1981

Parliamentary Pensions etc Act 1984

Parliamentary Constituencies Act 1986

Parliamentary and Health Service Commissioners Act 1987

Chevening Estate Act 1987

Parliamentary and other Pensions Act 1987

Parliamentary Corporate Bodies Act 1992

Parliamentary Commissioner Act 1994

Parliamentary Costs Act 2006

Parliament (Joint Departments) Act 2007

Parliamentary Standards Act 2009

Constitutional Reform and Governance Act 2010

repeal ss $20-47$

Fixed Term Parliaments Act 2011

Parliamentary Voting and Constituencies Act 2011

Recall Act 2015

House of Commons Commission Act 2015

\section{$\underline{\text { Schedule 1, Part } 2}$}

House of Lords Precedence Act 1539

Union with Scotland Act 1706, art 25(6)

Bishoprics Act 1878

Parliament Act 1911

Parliament Act 1949

House of Lords Act 1999

House of Commons (Removal of Clergy Disqualification) Act 2001

House of Lords Reform Act 2014.

House of Lords (Expulsion and Suspension) Act 2015

Lords Spiritual (Women) Act 2015

\section{Schedule 2}

Part 1. Judicial Offices (this will state those cited in $\mathrm{n} 288$ )

Part 2. Ministerial Offices (this will state those in $\mathrm{n} 289$ )

Part 3. Bodies of which all members are disqualified

Part 4. Other disqualifying offices

Part 5. Offices disqualifying for particular constituencies

\section{Schedule 3}

\section{CERTIFICATE OF VACANCY}

We, whose names are underwritten, being 2 members of the House of Commons, certify that [ ] member of Parliament for [ ] -

- $\quad$ died on [ ]; or

- $\quad$ has become disqualified as a peer from membership of the House Commons; or

- has accepted the office of [ ], the acceptance of which has been gazetted in the [ ] issue of the Gazette dated []

And, we give you this notice to the intent that you may issue your warrant to the Clerk of the Crown in Chancery to make out a new writ for the election of a member to serve as a member of Parliament in place of him.

To the Speaker of the House of Commons.

NOTE. If there is no Speaker, or if the Speaker is out of the UK, this certificate may be addressed to any one of the persons appointed under [s 20(3)] to exercise the Speaker's powers under that section.

\section{APPENDIX D}

An Act to abolish the House of Lords.

\section{1.}

(1) The House of Lords in Parliament is abolished.

(2) The High Court shall have jurisdiction to hear any peerage claim.

(3) The legislation in Schedule 1 is repealed. 
(4) Any legislation or common law matter attendant on, or consequential to, s 1(3) may be:
(a) repealed
(b) abolished; or
(c) amended,

by a SI.

\section{$\underline{\text { Schedule } 1}$}

House of Lords Precedence Act 1539

Union with Scotland Act 1706, art 25(6)

Bishoprics Act 1878

Parliament Act 1911

Parliament Act 1949

House of Lords Act 1999

House of Commons (Removal of Clergy Disqualification) Act 2001

House of Lords Reform Act 2014

House of Lords (Expulsion and Suspension) Act 2015

Lords Spiritual (Women) Act 2015

\section{Copyright}

Copyright for this article is retained by the author(s), with first publication rights granted to the journal.

This is an open-access article distributed under the terms and conditions of the Creative Commons Attribution license (http://creativecommons.org/licenses/by/4.0/). 